\title{
BIBLIOGRAPHY OF OKLAHOMA HYDROLOGY - REPORTS PREPARED BY THE U.S. GEOLOGICAL SURVEY AND PRINCIPAL COOPERATING AGENCIES, 1901-93
}

Compiled by John S. Havens

U.S. GEOLOGICAL SURVEY

Open-File Report 93-448

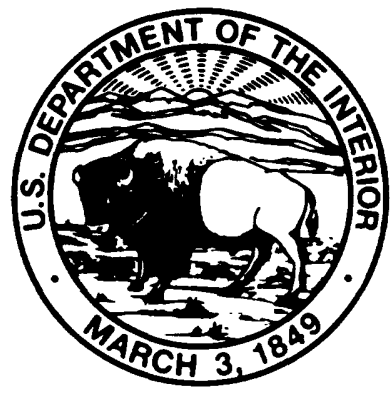

Oklahoma City, Oklahoma 1993 


\title{
U.S. DEPARTMENT OF THE INTERIOR
}

\author{
BRUCE BABBITT, Secretary
}

\author{
U.S. GEOLOGICAL SURVEY \\ ROBERT M. HIRSCH, Acting Director
}

For additional information write to:

District Chief

U.S. Geological Survey

202 NW 66th Street, Bldg. 7

Oklahoma City, Oklahoma 73116
Copies of this report can

be purchased from:

U.S. Geological Survey

Open-File Section

Federal Center

Box 25286

Denver, Colorado 80225 


\section{CONTENTS}

Introduction

Sources of U.S. Geological Survey publications

Oklahoma District library 3

Text products-Books and open-file reports .3

Maps .3

New publications .3

Information services 3

General information on Oklahoma water resources and publications .3

Public Inquiries Office ..................................

Computer data-base information .4

U.S. Geological Survey 5

Professional Papers .5

Water-Supply Papers .5

Hydrologic Investigations Atlases ....8

Miscellaneous Geologic Investigations ...9

Open-File Reports ....9

Water-Resources Investigations Reports 18

Federal Emergency Management Flood Insurance Studies .21

Water-Resources Data Reports . .23
Circulars 24

Annual Reports 24

Miscellaneous Reports and Maps .24

Oklahoma Water Resources Board............... 25

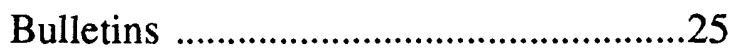

Hydrologic Investigation .........................26

Miscellaneous Reports ...............................26

Oklahoma Geological Survey ....................... 26

Bulletins .....................................................

Circulars ...................................................27

Mineral Reports ........................................28

Geologic Map ..........................................28

Educational Publication ...........................28

Hydrologic Atlases ...................................28

The Hopper and Oklahoma Geology Notes .................................................29

Special Publication ...................................30

Professional societies' abstracts and journal articles 30

Other miscellaneous reports........................... 33

Author index .............................................. 34

Subject index..................................................... 37

Reports by U.S. Geological Survey, sorted by report number. 48 


\title{
BIBLIOGRAPHY OF OKLAHOMA HYDROLOGY- REPORTS PREPARED BY THE U.S. GEOLOGICAL SURVEY AND PRINCIPAL COOPERATING AGENCIES, 1901-93
}

\author{
Compiled by John S. Havens
}

\section{INTRODUCTION}

The water resources mission of the U.S. Geological Survey is to provide hydrologic information needed by others to manage the Nation's water resources. Among other tasks, the Survey, in cooperation with State and local governments, and other Federal agencies:

- Collects data on a systematic basis to determine the quantity, quality, and use of surface and ground water, and the quality of precipitation.

- Conducts water-resources investigation and assessments at national, State, and local scales, characterizes water-resources conditions, and provides the capability to predict the effect on the resource of managerial actions, proposed development plans, and natural phenomena.

- Conducts basic and problem-oriented hydrologic and water-related research.

- Acquires information useful in predicting and eliminating water-related natural hazards.

- Disseminates data and the results of investigations through reports, maps, and other forms of public release.

- Provides scientific and technical assistance in hydrology to other Fed- eral agencies and to State and local agencies.

Reports on the hydrology of Oklahoma have been issued by the U.S. Geological Survey since 1901. Many of these reports have been prepared in cooperation with State and local agencies. Of the nearly 550 reports, abstracts, and journal ariticles issued from 1901 through July 1993, about 245 have been concerned primarily with ground water; the remainder have dealt with some aspect of surface water, water quality, or geology.

Early Annual Reports by the Director, U.S. Geological Survey, contained articles dealing with the geology of Oklahoma, specifically the Indian Territory coal fields in eastern Oklahoma. In 1901 and 1902, the Twenty-first and Twenty-second Annual Reports contained an article, "The High Plains and their utilization." C.N. Gould's 1905 "Geology and water resources of Oklahoma," U.S. Geological Survey Water-Supply Paper 148, was one of the first papers dealing with the hydrology of Oklahoma. Until the late 1930 's, only a few reports dealing with water resources of isolated areas were issued. In the late 1930's and early 1940's, intensive water-resources studies were begun in the Oklahoma Panhandle in northwestern Oklahoma, probably as a result of drought and dust-bowl conditions throughout the State. 
Records of ground-water-level data have been published since 1935. From 1935 through 1974 , these records were published as WaterSupply Papers, "Ground-water levels in the United States," in either an annual or 5-year compilation. Beginning with 1956-60 records and continuing until 1985, ground-water-level data for Oklahoma have been published annually in cooperation with the Oklahoma Water Resources Board.

Records of discharge or stage of streams, and contents or stage of lakes and reservoirs were published first in a series of Water-Supply Papers, "Surface-water supply of the United States." Through 1960 these reports were published in an annual or semiannual series and from 1961 through 1970 as 5-year compilations. From 1961 to the present, Oklahoma streamflow data have been published in cooperation with the State of Oklahoma and other agencies as a series of annual "WaterResources Data Reports."

Records of chemical analyses, water temperatures, and suspended sediment were published from 1941 to 1971 in an annual series of Water-Supply Papers entitled "Quality of surface water of the United States." Surfacewater-quality data for water years 1964 to the present have been published either as separate reports or in conjunction with the WaterResources Data Reports. Records of groundwater quality have been published on an irregular basis, either as part of a ground-water study or as separate reports.

Areal-investigations reports of groundwater occurrence may include tables of well information, geologic logs, geophysical logs, water-quality data, and surface-water data. Surface-water reports, in addition to the annual Water-Resources Data Reports, include investigations of floods, flood characteristics, surface-water quality, flow-frequency analyses and projection, statistical analyses of streamflow records, and surface-water resources of river basins. Water-quality reports include chemical analysis data and water-quality statistics of ground water and surface water, and water quality of lakes.

The most requested reports have been the annual Water-Resources Data Reports, which provide information on streamflow and water quality of Oklahoma streams for the year, and the reconnaissance Hydrologic Atlases prepared in cooperation with the Oklahoma Geological Survey, which contain maps of geology and hydrology of the State at a scale of $1: 250,000$.

In addition to reports issued by the U.S. Geological Survey, this bibliography lists selected journal articles and reports issued by the principal State cooperators, the Oklahoma Water Resources Board and Oklahoma Geological Survey, dealing with the hydrology and geology of Oklahoma. Many of these reports were written by U.S. Geological Survey authors and published by the cooperators. Some of these reports are now out-of-print; copies of most are available for inspection at the U.S. Geological Survey library in Oklahoma City.

An attempt has been made to include all older Open-File Reports pertaining to water resources in Oklahoma released over the years by the U.S. Geological Survey. A limited number of copies of some of these reports are available for distribution or a copy may be inspected at:

\section{U.S. Geological Survey \\ Water Resources Division 202 NW $66^{\text {th }}$, Building 7 \\ Oklahoma City, OK 73116}

In addition, open-file reports may be purchased from the Open-File Section, Denver. (See "Sources of U.S. Geological Survey Publications.")

Reports are listed in this bibliography first by publishing agency (U.S. Geological Survey, Oklahoma Water Resources Board, and Oklahoma Geological Survey), then by type of 
report (Professional Paper, Water-Supply Paper, and so forth), and last by author and date of publication. Author, subject, and report-number indexes are provided at the rear of this report.

\section{SOURCES OF U.S. GEOLOGICAL SURVEY PUBLICATIONS}

Since 1879, the U.S. Geological Survey has served the public, and Federal, State, and local governments by collecting, analyzing, and publishing detailed information about the Nation's mineral, land, and water resources. This information is in a variety of map, book, and other formats, and is available from several sources within the U.S. Geological Survey.

\section{Oklahoma District Library}

The Oklahoma District maintains a small library of selected publications, most dealing with the hydrology and geology of Oklahoma. The library is open to the public during regular office hours, 8:00-4:45, Monday through Friday.

\section{Text Products-Books and Open-File Reports}

To order U.S. Geological Survey book publications, catalogs, and pamphlets, and to obtain information on the availability of microfiche or duplicated paper copies of selected Open-File and Water-Resources Investigations Reports, write to:

\section{U.S. Geological Survey \\ Open-File Section \\ Federal Center \\ Box 25286 \\ Denver, CO 80225}

Streamflow data, water-quality data for surface and ground water, and ground-waterlevel data for Oklahoma are combined and published in the annual series, U.S. Geological Survey Water-Data Reports. These Water-Data Reports are for sale by:
National Technical Information Service

U.S. Department of Commerce

5285 Port Royal Road

Springfield, VA 22161

\section{Maps}

To order geologic, hydrologic, topographic, and land-use and land-cover maps published by the U.S. Geological Survey, write to:

U.S. Geological Survey

Map Distribution Section

Federal Center,

Box 25286

Denver, CO 80225

\section{New Publications}

To be added to the mailing list for the free monthly catalog "New Publications of the Geological Survey" write to:

U.S. Geological Survey

582 National Center

Reston, VA 22092

\section{INFORMATION SERVICES}

\section{General information on Oklahoma water resources and publications:}

For general information on water resources and availability of publications dealing with Oklahoma, contact:

Kathy D. Peter, District Chief

U.S. Geological Survey

Water Resources Division

$202 \mathrm{NW} 66^{\text {th }}$, Building 7

Oklahoma City, OK 73116

(405) 231-4256

\section{Public Inquiries Office}

Public Inquiries Offices of the U.S. Geological Survey provide general information about the Geological Survey's programs and its publications. The nearest Public Inquiries Office to the Oklahoma City area is: 
U.S. Geological Survey

Public Inquiries Office

169 Federal Building

1961 Stout Street Denver, CO 80294

(303) 844-4169

\section{Computer Data-Base Information}

The computer unit of the Oklahoma District of the U.S. Geological Survey manages the following data-base services that provide water-resources data:

NAtional Water Data EXchange (NAWDEX) provides information on the location and types of data available.
WATer Data STOrage and REtrieval System (WATSTORE) provides the following types of information:

1. Well depth, depth to water, yield, name of aquifer, water-quality, and well-construction data for more than 20,000 water wells in Oklahoma.

2. Current discharge and water-quality data collected from about 150 streams, lakes, and springs in Oklahoma.

3. Current peak-flow data from about 40 partial-record stations in Oklahoma. 


\title{
BIBLIOGRAPHY OF OKLAHOMA HYDROLOGY- REPORTS PREPARED BY THE U.S. GEOLOGICAL SURVEY AND PRINCIPAL COOPERATING AGENCIES, 1901-93
}

\section{Compiled by John S. Havens}

\begin{abstract}
[Revision of U.S. Geological Survey Open-File Report 89-33, with the addition of reports printed since publication of that report. Reports published from 1988 through July 1993 are marked with a pointing hand in the margin.]
\end{abstract}

\section{U.S. GEOLOGICAL SURVEY}

\section{Professional Papers}

Professional papers are mainly comprehensive scientific reports of wide and lasting interest and importance to professional scientists and engineers.

Bedinger, M.S., and Sneigocki, R.T., 1976, Summary appraisals of the Nation's ground-water resources-Arkansas-WhiteRed Region: U.S. Geological Survey Professional Paper 813-H, 31 p.

Bergman, D.L., and Sullivan, C.W., 1963, Channel changes on Sandstone Creek near Cheyenne, Oklahoma, in Geological Survey Research 1963: U.S. Geological Survey Professional Paper 475-C, p. C145-C148.

Clark, W.E., 1963, Evapotranspiration and relation of ground water to surface water in the Pond Creek basin, Oklahoma, in Geological Survey Research 1962: U.S. Geological Survey Professional Paper 450-E, p. E142-E145.

Leonard, A.R., and Ward, P.E., 1962, Use of $\mathrm{Na} / \mathrm{Cl}$ ratios to distinguish oil field from salt springs brines in western Oklahoma, in Geological Survey Research 1962: U.S. Geological Survey Professional Paper 450B, p. B126-B127.

U.S. Geological Survey, 1954, Water-loss investigations; Lake Hefner studies, techni- cal report: U.S. Geological Survey Professional Paper 269, 158 p.

Ward, P.E., 1962, Shallow halite deposits in the Flowerpot Shale in southwestern Oklahoma: U.S. Geological Survey Professional Paper 450-E, p. E40-E42.

Ward, P.E., and Leonard, A.R., 1961, Hypothetical circulation of ground water around salt springs in western Oklahoma, Texas, and Kansas, in Geological Survey Research 1961: U.S. Geological Survey, Professional Paper 424-D, p. D150-D151.

\section{Water-Supply Papers}

Water-supply papers include reports on the geology, hydrology, quality, recoverability, and utilization of water resources.

Bedinger, M.S., Reed, J.E., Wells, C.V., and Swafford, B.F., 1970, Methods and applications of electrical simulation in groundwater studies in the lower Arkansas and Verdigris River valleys, Arkansas and Oklahoma: U.S. Geological Survey Water-Supply Paper 1971, 71 p.

Blumer, S.P., 1986, Oklahoma, Surface-water resources, in U.S. Geological Survey, 1986, National Water Summary, 1985: U.S. Geological Survey Water-Supply Paper 2300, p. 375-382. 
Dover, T.B., Leonard, A.R., and Laine, L.L., 1968, Water for Oklahoma: U.S. Geological Survey Water-Supply Paper 1890, $107 \mathrm{p}$.

Gould, C.N., 1905, Geology and water resources of Oklahoma: U.S. Geological Survey Water-Supply Paper 148, 178 p.

Hanson, R.L., 1991, Evapotranspiration and droughts, in U.S. Geological Survey, 1991, National Water Summary 1988-89: U.S. Geological Survey Water-Supply Paper 2375, $591 \mathrm{p}$.

Havens, J.S., Marcher, M.V., and Schuelein, J.W., 1985, Oklahoma-Ground-water resources, in U.S. Geological Survey, 1985, National Water Summary 1984: U.S. Geological Survey Water-Supply Paper 2275, 467 p.

Heimann, D.C., Stoner, J.D., McTernan, E.W., and Schuelein, J.W., 1990, OklahomaWater supply and use, in U.S. Geological Survey, 1990, National Water Summary 1987: U.S. Geological Survey Water-Supply Paper 2350, 553 p.

Horak, W.F., and Stoner, J.D., 1988, Oklahoma-Ground-water quality, in U.S. Geological Survey, 1988, National Water Summary 1986: U.S. Geological Survey Water-Supply Paper 2325, 560 p.

Kennon, F.W., 1966, Hydrologic effects of small reservoirs in Sandstone Creek watershed, Beckham and Roger Mills Counties, western Oklahoma: U.S. Geological Survey Water-Supply Paper $1839-\mathrm{C}, 39$ p.

Leonard, A.R., 1963, Oklahoma, in The role of ground water in the Nation's water situation: U.S. Geological Survey Water-Supply Paper 1800, p. 671-698.

Marine, I.W., 1963, Correlation of water-level fluctuations with climatic cycles in the
Oklahoma Panhandle: U.S. Geological Survey Water-Supply Paper 1669-K, 10 p.

Renick, B.C., 1925, Additional water supplies for the city of Enid, Oklahoma: U.S. Geological Survey Water-Supply Paper 520-B, p. 15-26.

Schwenneson, A.T., 1915a, Ground water for irrigation in the vicinity of Enid, Oklahoma: U.S. Geological Survey Water-Supply Paper 345-B, p. 11-23

$1915 b$, Ground water for irrigation in the valley of North Fork of Canadian River near Oklahoma City, Oklahoma: U.S. Geological Survey Water-Supply Paper 345-D, p. 41-51.

Stoner, J.D., 1985, Dissolved solids in the Arkansas River Basin, in U.S. Geological Survey, 1985, National Water Summary 1984: U.S. Geological Survey Water-Supply Paper 2275, 467 p.

Tanaka, H.H., 1972, Geohydrology of the lower Verdigris River valley between Muskogee, and Catoosa, Oklahoma: U.S. Geological Survey Water-Supply Paper 1999-A, 23 p.

Tanaka, H.H., Hollowell, J.R., and Murphy, J.J., 1966, Hydrology of the alluvium of the Arkansas River, Muskogee, Oklahoma, to Fort Smith, Arkansas, with a section on Chemical quality of the water, by J.J. Murphy: U.S. Geological Survey Water-Supply Paper 1809-T, 42 p.

Thompson, D.C., 1922, Ground water for irrigation near Gage, Ellis County, Oklahoma: U.S. Geological Survey WaterSupply Paper 500-B, p. 33-53.

Tortorelli, R.L., Cooter, E.J., and Schuelein, J.W., 1991, Oklahoma-Floods and droughts, in U.S. Geological Survey, 1991, National Water Summary 1988-89: 
U.S. Geological Survey Water-Supply Paper 2375, $591 \mathrm{p}$.

U.S. Geological Survey, 1954, Floods of May 1951 in western Oklahoma and northwestern Texas: U.S. Geological Survey WaterSupply Paper 1227-B, p. 135-199.
1984, Oklahoma water issues, in U.S. Geological Survey, 1984, National Water Summary 1983-Hydrologic events and issues, U.S. Geological Survey WaterSupply Paper 2250, 243 p.

Water-Supply Papers containing ground-water-level data for Oklahoma

\begin{tabular}{cccc}
\hline $\begin{array}{c}\text { Calendar } \\
\text { Year }\end{array}$ & $\begin{array}{c}\text { Water-Supply } \\
\text { Paper }\end{array}$ & $\begin{array}{c}\text { Calendar } \\
\text { Year }\end{array}$ & $\begin{array}{c}\text { Water-Supply } \\
\text { Paper }\end{array}$ \\
\hline 1935 & 777 & 1948 & 1129 \\
1936 & 817 & 1949 & 1159 \\
1937 & 840 & 1950 & 1168 \\
1938 & 845 & 1951 & 1194 \\
1939 & 886 & 1952 & 1244 \\
1940 & 909 & 1953 & 1268 \\
1941 & 939 & 1954 & 1324 \\
1942 & 947 & 1955 & 1407 \\
1943 & 989 & $1956-59$ & 1549 \\
1944 & 1019 & $1960-64$ & 1824 \\
1945 & 1026 & $1965-69$ & 1979 \\
1946 & 1074 & $1970-74$ & 2172 \\
1947 & 1099 & & \\
\hline
\end{tabular}

Water-Supply Papers containing surface-water-quality data for Oklahoma

\begin{tabular}{cccc}
\hline $\begin{array}{c}\text { Water } \\
\text { Year }\end{array}$ & $\begin{array}{c}\text { Water-Supply } \\
\text { Paper }\end{array}$ & $\begin{array}{c}\text { Water } \\
\text { Year }\end{array}$ & $\begin{array}{c}\text { Water-Supply } \\
\text { Paper }\end{array}$ \\
\hline 1941 & 942 & 1957 & 1522 \\
1942 & 950 & 1958 & 1573 \\
1943 & 970 & 1959 & 1644 \\
1944 & 1022 & 1960 & 1744 \\
1945 & 1030 & 1961 & 1884 \\
1946 & 1050 & 1962 & 1944 \\
1947 & 1102 & 1963 & 1950 \\
1948 & 1133 & 1964 & 1957 \\
1949 & 1163 & 1965 & 1964 \\
1950 & 1188 & 1966 & 1994 \\
1951 & 1199 & 1967 & 2014 \\
1952 & 1252 & 1968 & 2096 \\
1953 & 1292 & 1969 & 2146 \\
1954 & 1352 & 1970 & 2156 \\
1955 & 1402 & 1971 & 2166 \\
1956 & 1452 & & \\
\hline
\end{tabular}


Water-Supply Papers containing surface-water data for Oklahoma

\begin{tabular}{|c|c|c|c|}
\hline $\begin{array}{l}\text { Wäter } \\
\text { Year }\end{array}$ & $\begin{array}{c}\text { Water-Supply } \\
\text { Paper }\end{array}$ & $\begin{array}{l}\text { Water } \\
\text { Year }\end{array}$ & $\begin{array}{c}\text { Water-Supply } \\
\text { Paper }\end{array}$ \\
\hline 1899 & 37 & 1932 & 732 \\
\hline 1900 & 50 & 1933 & 747 \\
\hline 1901 & $65,66,75$ & 1934 & 762 \\
\hline 1902 & 83,84 & 1935 & 787 \\
\hline 1903 & 98,99 & 1936 & 807 \\
\hline 1904 & 128,131 & 1937 & 827 \\
\hline 1905 & 169,173 & 1938 & 857 \\
\hline 1906 & 205,209 & 1939 & 877 \\
\hline $1907-08$ & 247 & 1940 & 897 \\
\hline 1909 & 267 & 1941 & 927 \\
\hline 1910 & 287 & 1942 & 957 \\
\hline 1911 & 307 & 1943 & 977 \\
\hline 1912 & 327 & 1944 & 1077 \\
\hline 1913 & 357 & 1945 & 1037 \\
\hline 1914 & 387 & 1946 & 1057 \\
\hline 1915 & 407 & 1947 & 1087 \\
\hline 1916 & 437 & 1948 & 1117 \\
\hline 1917 & 457 & 1949 & 1147 \\
\hline 1918 & 477 & 1950 & 1177 \\
\hline $1919-20$ & 507 & 1951 & 1211 \\
\hline 1921 & 527 & 1952 & 1241 \\
\hline 1922 & 547 & 1953 & 1281 \\
\hline 1923 & 567 & 1954 & 1341 \\
\hline 1924 & 587 & 1955 & 1391 \\
\hline 1925 & 607 & 1956 & 1441 \\
\hline 1926 & 627 & 1957 & 1511 \\
\hline 1927 & 647 & 1958 & 1561 \\
\hline 1928 & 667 & 1959 & 1631 \\
\hline 1929 & 687 & 1960 & 1711 \\
\hline 1930 & 702 & $1961-65$ & 1921 \\
\hline 1931 & 717 & $1966-70$ & 2121 \\
\hline
\end{tabular}

Hydrologic Investigations Atlases Christenson, S.C., Morton, R.B., and Multicolored or black and white maps on topographic or planimetric bases presenting a wide range of geohydrologic data; for both regular and irregular areas.

Bergman, D.L., and Tortorelli, R.L., 1988, Flood of May 26-27, 1984 in Tulsa, Oklahoma: U.S. Geological Survey Hydrologic Investigations Atlas HA-707, 1 sheet.

Mesander, B.A., 1992, Hydrogeologic maps of the Central Oklahoma aquifer, Oklahoma: U.S. Geological Survey Hydrologic Investigations Atlas HA-724, 3 sheets.

Hart, D.L., Jr., 1966, Base of fresh ground water in southern Oklahoma: U.S. Geological Survey Hydrologic Investi- 
gations Atlas HA-223, scale 1:250,000, 2 sheets.

Krothe, N.C., Oliver, J.W., and Weeks, J.B., 1982, Dissolved solids and sodium in water from the High Plains aquifer in parts of Colorado, Kansas, Nebraska, New Mexico, Oklahoma, South Dakota, Texas, and Wyoming: U.S. Geological Survey Hydrologic Investigations Atlas HA-658, scale $1: 2,500,000,2$ sheets.

Lohman, S.W., Burtis, V.M., and others, 1953a, Areas of principal ground-water investigations in the Arkansas, White, and Red River basins: U.S. Geological Survey Hydrologic Investigations Atlas HA-2, scale 1:2,500,000, 2 sheets.

$1953 \mathrm{~b}$, General availability of ground water and depth to water level in the Arkansas, White, and Red River basins: U.S. Geological Survey Hydrologic Investigations Atlas HA-3, scale 1:2,500,000.

Luckey, R.R., Gutentag, E.D., and Weeks, J.B., 1981, Water-level and saturated-thickness changes, predevelopment to 1980 , in the High Plains aquifer in parts of Colorado, Kansas, Nebraska, New Mexico, Oklahoma, South Dakota, Texas, and Wyoming: U.S. Geological Survey Hydrologic Investigations Atlas HA-652, scale $1: 2,500,000,2$ sheets.

Morton, R.B., and Goemaat, R.L., 1972, Reconnaissance of the water resources of Beaver County, Oklahoma: U.S. Geological Survey Hydrologic Investigations Atlas HA-450, scale 1:125,000, 3 sheets.

Sapik, D.B., and Goemaat, R.L., 1972, Reconnaissance of the ground-water resources of Cimarron County, Oklahoma: U.S. Geological Survey Hydrologic Investigations Atlas HA-373, scale 1:125,000, 3 sheets.

Weeks, J.B., and Gutentag, E.D., 1981, Bedrock geology, altitude of base, and 1980 saturated thickness of the High Plains aquifer in parts of Colorado, Kansas, Nebraska,
New Mexico, Oklahoma, South Dakota, Texas, and Wyoming: U.S. Geological Survey Hydrologic Investigations Atlas HA648 , scale $1: 2,500,000,2$ sheets.

Wood, P.R., and Hart, D.L., Jr., 1967, Availability of ground water in Texas County, Oklahoma: U.S. Geological Survey Hydrologic Investigations Atlas HA-250, scale $1: 125,000,3$ sheets.

\section{Miscellaneous Geologic Investigations}

Maps on planimetric or topographic bases; regular and irregular areas; various scales; with a wide variety of format and subject matter.

Morton, R.B., 1973, Preliminary investigations of the hydrogeology of the Middle Permian to Tertiary rocks of the Oklahoma Panhandle: U.S. Geological Survey Miscellaneous Geologic Investigations Map I-738, scale approximately $1: 250,000$, 2 sheets.

\section{Open-File Reports}

Open-file reports include unpublished manuscript reports, maps, and other material and are made available for public consultation and use. They are a nonpermanent form of publication that may be cited in other publications as sources of information.

Andreasen, G.E., and Bromery, R.W., 1963, Total intensity aeromagnetic profiles over northeastern Oklahoma: U.S. Geological Survey Open-File Report 63-3, 1 map, in 2 parts.

Barclay, J.E., 1951, Ground-water levels in Oklahoma: U.S. Geological Survey OpenFile Report 51-200, 3 p.

Bednar, G.A., and Waldrep, T.E., 1973, Fluvial sediment in Double Creek sub-watershed no. 5, Washington County, Oklahoma: U.S. Geological Survey Open-File Report 73-22, $38 \mathrm{p}$.

Bergman, D.L., and Huntzinger, T.L., 1981, Rainfall-runoff hydrographs and basin char- 
acteristics data for small streams in Oklahoma: U.S. Geological Survey Open-File Report 81-824, 320 p.

Bingham, R.H., 1969, Ground-water levels in observation wells in Oklahoma, 1967-68: U.S. Geological Survey Open-File Report 69-335, $92 \mathrm{p}$.

Blumer, S.P., 1983, Sediment data for MidArkansas and Upper Red River basins through 1980: U.S. Geological Survey Open-File Report 83-692, 799 p.

Blumer, S.P., and Alf, L.A., 1986, Hydrologic data for selected streams in the coal area of southeastern Oklahoma, July 1978 to September 1982: U.S. Geological Survey Open-File Report 86-319, 337 p.

Blumer, S.P., and Hauth, L.D., 1984, Use and availability of continuous streamflow records in Oklahoma: U.S. Geological Survey Open-File Report 84-747, 23 p.

Blumer, S.P., and Scott, J.C., 1984, Hydrologic data for the Lehigh area, southeastern Oklahoma, May 1977 to January 1982: U.S. Geological Survey Open-File Report 84-599, 212 p.

Bohn, J.D., and Hoffman, G.L., 1970, A proposed streamflow data program for Oklahoma: U.S. Geological Survey Open-File Report 70-32, 44 p.

Breit, G.N., 1992, Mineralogy and petrography of Permian rocks in the Central Oklahoma aquifer: Implications for groundwater quality [abs.]: in Christenson, Scott, and Carpenter, Lyn, 1992, eds., Groundwater quality of the Central Oklahoma (Garber-Wellington) aquifer conference: Proceedings, February 20, 1992: U.S. Geological Survey Open-File Report 92-116, p. 12-13.

$\rightarrow$

Breit, G.N., Mosier, E.L., Schlottmann, J.L., and Papp, C.S.E., 1990, Rock/water interactions and ground-water contamination in Permian rocks, Central Oklahoma aquifer: in Gough, L.P., ed., 1990, Environmental forum 1990: Geoscience investigations that emphasize chemical, physical, and biological ecosystem processes: U.S. Geological Survey Open-File Report 90-288, 21 p.

Breit, G.N., Rice, Cyndi, Esposito, Ken, and Schlottmann, J.L., 1990, Mineralogy and petrography of Permian rocks in the Central Oklahoma aquifer: U.S. Geological Survey Open-File Report 90-678, 50 p.

Buckner, H.D., and Kurklin, J.K., 1984, Floods in south-central Oklahoma and north-central Texas: U.S. Geological Survey Open-File Report 84-065, 112 p.

Cady, R.C., 1937 (?), Ground water in Creek County, Oklahoma: U.S. Geological Survey Open-File Report 37-2, 12 p.

Carr, J.E., and Havens, J.S., 1976, Records of wells and water quality for the GarberWellington aquifer, northern Oklahoma and southern Logan Counties, Oklahoma: U.S. Geological Survey Open-File Report $76-619,32 \mathrm{p}$.

Carr, J.E., and Marcher, M.V., 1977, A preliminary appraisal of the Garber-Wellington aquifer, southern Logan and northern Oklahoma Counties, Oklahoma: U.S. Geological Survey Open-File Report 77-278, 23 p.

Christenson, Scott, 1992, Geohydrology and ground-water flow simulation of the Central Oklahoma aquifer [abs.]: in Christenson, Scott, and Carpenter, Lyn, 1992, eds., Ground-water quality of the Central Oklahoma (Garber-Wellington) aquifer conference: Proceedings, February 20, 1992: U.S. Geological Survey Open-File Report 92116 , p. 5-6.

Christenson, Scott, and Carpenter, Lyn, eds., 1992, Ground-water quality of the Central Oklahoma (Garber-Wellington) aquifer conference: Proceedings, February 20, 1992: U.S. Geological Survey Open-File Report 92-116, 24 p. 
Christenson, S.C., Morton, R.B., Havens, J.S., and Fairchild, R.W., 1988, Geologic logs for selected deep wells in parts of Oklahoma, Texas, and New Mexico: U.S. Geological Survey Open-File Report 86-541, $161 \mathrm{p}$.

Christenson, S.C., Morton, R.B., and Mesander, B.A., 1990, Hydrogeologic maps of the Central Oklahoma aquifer, Oklahoma: U.S. Geological Survey Open-File Report 90-579, 3 sheets. [Published as U.S. Geological Survey Hydrologic Investigations Atlas HA-724, 3 sheets.]

Christenson, S.C., and Parkhurst, D.L., 1987, Ground-water quality assessment of the Central Oklahoma aquifer, Oklahoma: Project Description: U.S. Geological Survey Open-File Report 87-235, 30 p.

Christenson, S.C., Parkhurst, D.L., and Fairchild, R.W., 1990, Geohydrology and water

quality of the Roubidoux aquifer, northeastern Oklahoma: U.S. Geological Survey Open-File Report 90-570, 109 p., 1 plate.

Christenson, S.C., Thomas, T.B., Overton, M.D., Goemaat, R.L., and Havens, J.S., 1991, Geophysical logs for selected wells in the Picher field, northeast Oklahoma and southeast Kansas: U.S. Geological Survey Open-File Report 91-213, 95 p.

Corley, R.K., and Huntzinger, T.L., 1979, Flood of August 27-28, 1977, West Cache Creek and Blue Beaver Creek, southwestern Oklahoma: U.S. Geological Survey Open-File Report 79-256, scale 1:24,000, 1 sheet.

D'Lugosz, J.J., and McClaflin, R.G., 1977, Hydrologic data for the Vamoosa aquifer, east-central Oklahoma: U.S. Geological Survey Open-File Report 77-487, 38 p.

1978, Geohydrology of the Vamoosa aquifer, east-central Oklahoma: U.S. Geological Survey Open-File Report 78-781, $63 \mathrm{p}$.
Davis, L.V., 1955, Ground-water investigations in Oklahoma: U.S. Geological Survey Open-File Report 55-36, 4 p.

Davis, L.V., and Schoff, S.L., 1948, Ground water in the Blanchard area, McClain County, Oklahoma: U.S. Geological Survey Open-File Report 48-80, 11 p.

Davis, R.E., and Christenson, S.C., 1981, Geohydrology and numerical simulation of the alluvium and terrace aquifer along the Beaver-North Canadian River from the Panhandle to Canton Lake, northwestern Oklahoma: U.S. Geological Survey OpenFile Report 81-483, 42 p.

Davis, R.E., Christenson, S.C., and Blumer, S.P., 1980, Hydrologic data for the alluvium and terrace aquifer along the Beaver-North Canadian River from the Panhandle to Canton Lake, northwestern Oklahoma: U.S. Geological Survey Open-File Report 80-159, 77 p.

Davis, R.E., and Hart, D.L., Jr., 1978, Hydrologic data for the Antlers aquifer, southeastern Oklahoma: U.S. Geological Survey Open-File Report 78-1038, 24 p.

Dennis, P.E., 1950, Geology and ground-water hydrology of the Lake Hefner area in Oklahoma County, Oklahoma: U.S. Geological Survey Open-File Report 50-68, 19 p.

Dover, T.B., 1950, Mineral constituents in water and their significance: U.S. Geological Survey Open-File Report 50-69, 6 p.

1957, Chemical quality of surface waters in the Arkansas River basin of Oklahoma: U.S. Geological Survey Open-File Report 57-40, $13 \mathrm{p}$.

Dover, T.B., and Geurin, J.W., 1953(?), Changes in chemical quality of the Arkansas River in Oklahoma and Texas [194652]: U.S. Geological Survey Open-File Report 53-289, 33 p.

Ellis, A.J., 1918, Sources of water supply for the military establishments at Fort Sill, 
Oklahoma: U.S. Geological Survey OpenFile Report 18-1, $11 \mathrm{p}$.

Fader, S.W., and Morton, R.B., 1975, Ground water in the Verdigris River basin, Kansas and Oklahoma: U.S. Geological Survey Open-File Report 75-365, 26 p.

1975, Ground water in the middle Arkansas River basin, Kansas and Oklahoma: U.S. Geological Survey Open-File Report 75-367, $44 \mathrm{p}$.

Fairchild, R.W., 1983, Hydrologic data for Arbuckle Mountain area, south-central Oklahoma: U.S. Geological Survey OpenFile Report 83-28, 74 p.

Fairchild, R.W., Hanson, R.L., and Davis, R.E., 1982, Hydrology of the Arbuckle Mountain area: U.S. Geological Survey Open-File Report 82-775, 153 p.

Ferree, D.M., 1983, Ground-water quality data for Oklahoma, 1981: U.S. Geological Survey Open-File Report 83-686, 78 p.

1985 , Ground-water quality data for Oklahoma-1982-84: U.S. Geological Survey Open-File Report 85-417, 43 p.

Ferree, D.M., Christenson, Scott, Rea, A.H., and Mesander, B.A., 1992, Ground-waterquality assessment of the Central Oklahoma aquifer, Oklahoma: Hydrologic, waterquality, and quality-assurance data 198790: U.S. Geological Survey Open-File Report 92-641, 193 p.

Goemaat, R.L., 1976, Ground-water levels in observation wells in Oklahoma, 1971-74: U.S. Geological Survey Open-File Report 76-664, $142 \mathrm{p}$.

1977a, Selected water-level records for western Oklahoma, 1950-75: U.S. Geological Survey Open-File Report 77-73, $94 \mathrm{p}$.

1977b, Ground-water levels in observation wells in Oklahoma, 1975:
U.S. Geological Survey Open-File Report 77-238, $35 \mathrm{p}$.

$1977 \mathrm{c}$, Selected water-level records for western Oklahoma, 1975-76: U.S. Geological Survey Open-File Report 77-239, $50 \mathrm{p}$.

Goemaat, R.L., Mize, L.D., Madaj, A.J., and Spiser, D.E., 1986, Ground-water levels in observation wells in Oklahoma, period of record to March 1985: U.S. Geological Survey Open-File Report 86-314, 461 p.

Goemaat, R.L., Mize, D.L., and Spiser, D.E., 1983, Ground-water levels in observation wells in Oklahoma, 1980-82: U.S. Geological Survey Open-File Report 83-760, $604 \mathrm{p}$.

1984 , Ground-water levels in observation wells in Oklahoma, 1982-83 climatic years: U.S. Geological Survey Open-File Report 84-472, 583 p.

1985, Ground-water levels in observation wells in Oklahoma, 1983-84 climatic years: U.S. Geological Survey Open-File Report 85-87, $588 \mathrm{p}$.

Goemaat, R.L., and Spiser, D.E., 1978, Selected water-level records for Oklahoma, 1975-77: U.S. Geological Survey OpenFile Report 78-721, 58 p.

1979 , Selected water-level records for Oklahoma, 1976-78: U.S. Geological Survey Open-File Report 79-1580, 48 p.

Goemaat, R.L., and Willard, C.C., 1983, Ground-water records for the area surrounding the Chickasaw National Recreation Area, Murray County, Oklahoma: U.S. Geological Survey Open-File Report 83-27, 13 p.

Gould, C.N., and Schoff, S.L., 1939, Geological report on water conditions at Platt National Park, Oklahoma: National Park Service Report 249, 38 p., 3 plates. [Also cataloged as U.S. Geological Survey OpenFile Report 39-14.] 
Gutentag, E.D., and Weeks, J.B., 1980, Water table in the High Plains aquifer in 1978 in parts of Colorado, Kansas, Nebraska, New Mexico, Oklahoma, South Dakota, and Wyoming: U.S. Geological Survey OpenFile Report $80-50$, scale 1:2,500,000, 1 sheet.

Hall, A.E., and Scott, J.C., 1991, Cooperative activities of the U.S. Geological Survey with historically black colleges and universities, fiscal year 1983-90: U.S. Geological Survey Open-File Report 91-90, 19 p.

Hanson, R.L., 1984, Droughts: U.S. Geological Survey Open-File Report 84-724, p. 773-811, in Carla Kitzmiller, compiler, 1984, Proceeding of the geologic and hydrologic hazards training program: U.S. Geological Survey Open-File Report 84-760, 1,112 p.

Hanson, R.L., Scott, J.C., and Kurklin, J.K., 1983, Oklahoma: A summary of activities of the U.S. Geological Survey, Water Resources Division for 1983: U.S. Geological Survey Open-File Report 83-767, 104 p.

Hart, D.L., Jr., 1961, Ground water in the alluvium of Beaver Creek basin, Oklahoma: U.S. Geological Survey Open-File Report $61-59,13 \mathrm{p}$.

1963, Ground-water levels in observation wells in Oklahoma, 1956-60: U.S. Geological Survey Open-File Report 63-150, $196 \mathrm{p}$.

1967, Ground-water levels in observation wells in Oklahoma, 1965-66: U.S. Geological Survey Open-File Report 67-285, $61 \mathrm{p}$.

Hart, D.L., Jr., and Davis, R.E., 1978, Geohydrology of the Antlers area, southeastern Oklahoma: U.S. Geological Survey openfile report, 35 p. [Released as Oklahoma Geological Survey Circular 81.]
Hart, D.L., Jr., Hoffman, G.L., and Goemaat, R.L., 1972, Records of water-level measurements in the Oklahoma Panhandle, 1971-72: U.S. Geological Survey OpenFile Report 72-464, 39 p.

Hart, D.L., Jr., and others, 1971, Records of water-level measurements in wells in the Oklahoma Panhandle, 1966-70: U.S. Geological Survey Open-File Report 71-344, $66 \mathrm{p}$.

Hauth, L.D., 1985, Floods in central, southwest Oklahoma, October 17-23, 1983: U.S. Geological Survey Open-File Report 85-494, $17 \mathrm{p}$.

Havens, J.S., 1978a, Ground-water records for eastern Oklahoma, Part 2, water-quality records for wells, test-holes, and springs: U.S. Geological Survey Open-File Report 78-357, 139 p.

1978b, Reconnaissance of ground water in the vicinity of the Wichita Mountains, southwestern Oklahoma: U.S. Geological Survey Open-File Report 78-857, 27 p. [Published as Oklahoma Geological Survey Circular 85.]

1985, Hydrologic data: North Canadian River from Lake Overholser to Lake Eufaula, central Oklahoma: U.S. Geological Survey Open-File Report 84-808, 52 p.

1988a, Oklahoma, a summary of activities of the U.S. Geological Survey, Water Resources Division, in fiscal years 198687: U.S. Geological Survey Open-File Report 88-172, 141 p.

1988b, U.S. Geological Survey ground-water studies in Oklahoma: U.S. Geological Survey Open-File Report 88-140, 2 p.

1989, Bibliography of Oklahoma hydrology-Reports prepared by the U.S. Geological Survey and principal cooperating agencies, 1901-88: U.S. Geological Survey Open-File Report 89-33, 59 p. 
1991, Oklahoma, a summary of activities of the U.S. Geological Survey, Water Resources Division, in fiscal years 198890: U.S. Geological Survey Open-File Report 91-492, 101 p.

Havens, J.S., and Bergman, D.L., 1976a, Ground-water records for southeastern Oklahoma-Part 1, Records of wells, test holes, and springs: U.S. Geological Survey Open-File Report 76-889, 59 p.

1976b, Ground-water records for northeastern Oklahoma-Part 1, Records of wells, test holes, and springs: U.S. Geological Survey Open-File Report 76-890, $100 \mathrm{p}$.

Hoffman, G.L., and Hart, D.L., Jr., 1973, Records of selected water wells and test holes in the Oklahoma Panhandle: U.S. Geological Survey Open-File Report 73-376, 59 p.

Hollowell, J.R., 1961a, Ground water in the alluvium of Elk Creek basin, Oklahoma: U.S. Geological Survey Open-File Report $61-65,20 \mathrm{p}$. [Also published as Oklahoma Water Resources Board Bulletin 28, 15 p.]

$1961 b$, Ground water in the vicinity of Roosevelt, Oklahoma: U.S. Geological Survey Open-File Report 61-67, 8 p.

Horak, W.F., and Stoner, J.D., 1988, Oklahoma ground-water quality: U.S. Geological Survey Open-File Report 87-746, 9 p.

Huntzinger, T.L., 1978a, High-flow frequencies for selected streams in Oklahoma: U.S. Geological Survey Open-File Report 78-161, $30 \mathrm{p}$.

1978b, Low-flow characteristics of Oklahoma streams: U.S. Geological Survey Open-File Report 78-166, 93 p.

1978c, Application of hydraulic and hydrologic data in urban storm water management: U.S. Geological Survey OpenFile Report 78-414, $33 \mathrm{p}$.
Jacobsen, C.L., 1951, Memorandum on ground water from Mississippian rocks in the vicinity of Miami, Okla.: U.S. Geological Survey Open-File Report 51-120, 9 p., 1 fig.

Jacobsen, C.L., and Reed, E.W., 1951, Memorandum on results of pumping tests at Goodrich plant site, Miami, Okla.: U.S. Geological Survey Open-File Report 51-121, 11 p., 13 graphs, 3 figs.

Kurklin, J.K., 1979, Statistical summaries of surface-water-quality data for selected sites in Oklahoma, through the 1975 water year: U.S. Geological Survey Open-File Report 79-219, $185 \mathrm{p}$.

Laine, L.L., 1956, Surface-water resources of Polecat Creek basin, Oklahoma: U.S. Geological Survey Open-File Report 56-75, 20 p., 2 figs.

1958a, Surface-water resources of the Washita River basin in Oklahoma-magnitude, distribution, and quality of streamflow: U.S. Geological Survey Open-File Report 58-58, 34 p.

1958b, Surface waters of North Boggy Creek basin in the Muddy Boggy Creek basin in Oklahoma, with a section on Chemical character of surface water, by T.B. Dover: U.S. Geological Survey OpenFile Report 58-59, 34 p.

1959a, Surface waters of Little River basin in central Oklahoma, with a section on Chemical character of surface waters, by T.B. Dover: U.S. Geological Survey OpenFile Report 59-75, 47 p.

1959b, Surface waters of Illinois River basin in Arkansas and Oklahoma, with a section on Chemical character of surface waters, by T.B. Dover: U.S. Geological Survey Open-File Report 59-76, 65 p. 
-1959 c, Correlative estimates of discharge for Verdigris River (tributary to Arkansas River) near Tenapah, Oklahoma, for year ending September 30, 1938: U.S. Geological Survey Open-File Report 59-77, 2 p.

1962, Surface waters of Cottonwood Creek in the Cimarron River basin in central Oklahoma, with a section on Chemical quality of surface waters, by R.P. Orth: U.S. Geological Survey Open-File Report $62-75,41 \mathrm{p}$.

1963, Surface water of Kiamichi River basin in southeastern Oklahoma, with a section on Quality of water, by T.R. Cummings: U.S. Geological Survey open-file report, $39 \mathrm{p}$.

Laine, L.L., and Murphy, J.J., 1962, Surface water of Beaver Creek basin in south-central Oklahoma: U.S. Geological Survey Open-File Report 62-162, 28 p.

Laine, L.L., Schoff, S.L., and Dover, T.B., 1951, Public water supplies in Oklahoma: U.S. Geological Survey Open-File Report 51-201, $110 \mathrm{p}$.

Leonard, A.R., 1960, Ground water in Oklahoma: U.S. Geological Survey Open-File Report 60-166, 12 p.

Leonard, A.R., Davis, L.V., and Stacy, B.L., 1958, Ground water in the alluvial deposits of the Washita River and its tributaries in Oklahoma: U.S. Geological Survey OpenFile Report 58-63, 13 p.

MacLachlan, M.E., 1964, The Anadarko Basin (of parts of Oklahoma, Texas, Kansas, and Colorado): U.S. Geological Survey OpenFile Report 64-112, 75 p.

Mills, W.B., and Spiser, D.E., 1980, Selected water-level records for Oklahoma, 197980: U.S. Geological Survey Open-File Report 80-975, $55 \mathrm{p}$.

Mize, L.D., 1975, Statistical summaries of streamflow records, Oklahoma, through
1974: U.S. Geological Survey Open-File Report 75-684, 399 p.

Moore, R.L., 1972, Ground-water levels in observation wells in Oklahoma, 1969-70: U.S. Geological Survey Open-File Report 72-463, 85 p.

Morton, R.B., 1980, Digital-model projection of saturated thickness and recoverable water in the Ogallala aquifer, Texas County, Oklahoma: U.S. Geological Survey OpenFile Report 79-565, 34 p.

Morton, R.B., and Fader, S.W., 1975, Ground water in the Grand (Neosho) River basin, Kansas and Oklahoma: U.S. Geological Survey Open-File Report 75-366, 35 p.

Mosier, E.L., Briggs, P.H., Crock, J.G., Kennedy, K.R., McKown, D.M., Vaughn, R.B., Welsch, E.P., 1990, Analyses of subsurface Permian rock samples from the Central Oklahoma aquifer: U.S. Geological Survey Open-File Report 90-456, 65 p.

Mosier, E.L., Bullock, J.H., Jr., Fey, D.L., Kennedy, K.R., McKown, D.M., Vaughn, R.B., and Welsch, E.P., 1991, Elemental composition of surficial materials from central Oklahoma: U.S. Geological Survey Open-File Report 91-442, 62 p.

Mosier, E.L., Papp, C.S.E., Motooka, J.M., Kennedy, K.R., and Riddle, G.O., 1991, Sequential extraction analyses of drill core samples, Central Oklahoma aquifer: U.S. Geological Survey Open-File Report 91$347,42 \mathrm{p}$.

Mosier, E.L., and Schlottmann, J.L., 1992, Geochemical studies of solid-phase materials in the Central Oklahoma aquifer-relation to water quality [abs.]: in Christenson, Scott, and Carpenter, Lyn, 1992, eds., Ground-water quality of the Central Oklahoma (Garber-Wellington) aquifer conference: Proceedings, February 20, 1992: U.S. Geological Survey Open-File Report 92116 , p. 10-11. 
Parkhurst, D.L., 1987, Chemical analyses of water samples from the Picher mining area, northeast Oklahoma and southeast Kansas: U.S. Geological Survey Open-File Report 87-453, $43 \mathrm{p}$.

Parkhurst, D.L., 1992, The geochemical evolution of ground waters in the Central Oklahoma aquifer [abs.]: in Christenson, Scott, and Carpenter, Lyn, 1992, eds., Groundwater quality of the Central Oklahoma (Garber-Wellington) aquifer conference: Proceedings, February 20, 1992: U.S. Geological Survey Open-File Report 92-116, p. 7-9.

Parkhurst, D.L., Christenson, S.C., and Schlottmann, J.L., 1989, Ground-water quality assessment of the Central Oklahoma aquifer, Oklahoma-Analysis of available water-quality data through 1987: U.S. Geological Survey Open-File Report 88-728, $80 \mathrm{p}$.

Parkhurst, D.L., Christenson, Scott, and Breit, G.N., 1993, Ground-water-quality assessment of the Central Oklahoma aquifer, Oklahoma: Geochemical and geohydrologic investigations: U.S. Geological Survey Open-File Report 92-642, 113 p. [In press]

Parkhurst, D.L., Doughten, Michael, and Hearn, P.P., 1988, Chemical analyses of stream sediment in the Tar Creek basin of the Picher mining area, northeast Oklahoma: U.S. Geological Survey Open-File Report 88-469, 13 p.

Playton, S.J., and Davis, R.E., 1977, Preliminary report on the quality of water in abandoned zinc mines in northeastern Oklahoma and southeastern Kansas: U.S. Geological Survey Open-File Report 77-163, 36 p.

Playton, S.J., Davis, R.E., and McClaflin, R.G., 1980, Chemical quality of water in abandoned zinc mines in northeastern Oklahoma and southeastern Kansas: U.S. Geological Survey Open-File Report 78-294,
67 p. [Published as Oklahoma Geological Survey Circular 82.]

Rea, Alan, and Christenson, Scott, 1992, Factors related to ground-water quality in the Oklahoma City urban area [abs.]: in Christenson, Scott, and Carpenter, Lyn, 1992, eds., Ground-water quality of the Central Oklahoma (Garber-Wellington) aquifer conference: Proceedings, February 20, 1992: U.S. Geological Survey Open-File Report 92-116, p. 21-22.

Rea, A.H., and Scott, J.C., 1990, A computer program to determine map coordinates from public land-survey coordinates [abs.]: in Balthrop, B.H, and Baker, E.G., 1990 , U.S. Geological Survey national computer technology meeting: Program and abstracts, May 7-11, 1990: U.S. Geological Survey Open-File Report 90-161, p. 33.

Schlottmann, J.L., and Funkhouser, R.A., 1991, Chemical analyses of water samples and geophysical logs from cored test holes drilled in the Central Oklahoma aquifer: U.S. Geological Survey Open-File Report 91-464, 58 p.

Schoff, S.L., 1948a, Ground-water conditions in the vicinity of Enid, Oklahoma: U.S. Geological Survey Open-File Report 48-81, 4 p.

1948b, Ground-water in the Beggs area, Okmulgee County, Oklahoma: U.S. Geological Survey Open-File Report 48-82, 7 p.

1948c, Ground-water available in the Davenport area [Lincoln County], Oklahoma: U.S. Geological Survey Open-File Report 48-83, 6 p.

1948d, Ground water in the Anadarko area [Caddo County], Oklahoma: U.S. Geological Survey Open-File Report 48-84, $7 \mathrm{p}$. 
Schoff, S.L., and Davis, L.V., 1948, Ground water in the Blanchard area, McClain County, Oklahoma: U.S. Geological Survey open-file report.

Schoff, S.L., Dott, R.H., and Lalicker, D.G., 1941, Contamination of Lake Wewoka and fresh-water sands by disposal of oil-well brines near Wewoka, Seminole County, Oklahoma: U.S. Geological Survey OpenFile Report 41-32, 8 p.

Slack, L.J., and Blumer, S.P., 1984, Physical and chemical characteristics of water in coal-mine ponds, eastern Oklahoma, June to November 1977-81: U.S. Geological Survey Open-File Report 84-446, 185 p. [Published as Oklahoma Geological Survey Special Publication 87-2.]

Stacy, B.L., 1960, Ground water in the alluvial deposits of Cottonwood Creek basin, Oklahoma: U.S. Geological Survey Open-File Report 60-130, 8 p.

1961 , Ground-water resources of the alluvial deposits of the Canadian River valley near Norman, Oklahoma: U.S. Geological Survey Open-File Report 61-177, 61 p.

Stoner, J.D., 1977, Index of published surfacewater-quality data for Oklahoma, 19461975: U.S. Geological Survey Open-File Report 77-204, 212 p.

1980, Reconnaissance of polychlorinated biphenyls in the Arkansas River between Muskogee and Webbers Falls Lock and Dam, Oklahoma: U.S. Geological Survey Open-File Report 80-216, 6 p.

Tanaka, H.H., 1960, Water-level and waterlevel change maps for the irrigation area in the Rush Springs sandstone in Caddo County and adjacent area: U.S. Geological Survey Open-File Report 60-138, 4 maps.

Tanaka, H.H., Hart, D.L., Jr., and Knott, R.K., 1965a, Ground-water data of selected test holes and wells along the Arkansas River in Muskogee County, Oklahoma: U.S. Geo- logical Survey Open-File Report 65-155, $287 \mathrm{p}$.

$1965 \mathrm{~b}$, Ground-water data of selected test holes and wells along the Verdigris River in Wagoner and Rogers Counties Oklahoma: U.S. Geological Survey OpenFile Report 65-156, 411 p.

$1965 \mathrm{c}$, Ground-water data of selected test holes and wells along the Arkansas River in Sequoyah County, Oklahoma: U.S. Geological Survey Open-File Report 65-157, 238 p.

1965d, Ground-water data of selected test holes and wells along the Arkansas River in LeFlore and Haskell Counties, Oklahoma: U.S. Geological Survey OpenFile Report 65-158, 236 p.

Theis, C.V., 1934, Preliminary geological report on the Salt Plains reservoir site [Alfalfa County], Oklahoma: U.S. Geological Survey Open-File Report 34-2, 15 p.

Thomas, W.O., Jr., and Corley, R.K., 1974, Floodflows from small drainage areas in Oklahoma: Progress report and data compilation: U.S. Geological Survey Open-File Report 74-1099, 50 p.

Tortorelli, R.L., Huntzinger, T.L., Bergman, D.L., and Patneaude, A.L., Jr., 1983, Urban flood analysis in Oklahoma City, Oklahoma: U.S. Geological Survey Open-File Report 83-26, 94 p.

Turner, S.F., 1931, Report on water supply for the proposed Southwestern Reformatory at El Reno, Oklahoma: U.S. Geological Survey Open-File Report 31-1, 20 p.

U.S. Geological Survey, 1945a, Water facts for Oklahoma: U.S. Geological Survey OpenFile Report 45-110, 35 p.

$1945 b$, Chemical analyses of surface waters in Oklahoma, September-December 1944: U.S. Geological Survey Open-File Report 45-111, 51 p. 
1953(?), Summary of annual records of chemical quality of the Arkansas River in Oklahoma and Arkansas, 1945-1952: U.S. Geological Survey Open-File Report 53-288, $38 \mathrm{p}$.

1966, Ground water in the Cimarron River basin, New Mexico, Colorado, Kansas, and Oklahoma: U.S. Geological Survey Open-File Report 66-159, $51 \mathrm{p}$.

1985, Oklahoma: A summary of activities of the U.S. Geological Survey, Water Resources Division, for 1985: U.S. Geological Survey Open-File Report 85-328, $129 \mathrm{p}$.

Ward, P.E., 1961, Geology and ground-water features of salt springs, seeps, and plains in the Arkansas and Red River basins of western Oklahoma and adjacent parts of Kansas and Texas: U.S. Geological Survey OpenFile Report 63-132, 94 p.

Weiss, D.L., and Sullivan, C.L., 1958(?), Floods of April-June 1957 in Oklahoma and western Arkansas: U.S. Geological Survey Open-File Report 57-127, 21 p.

Westfall, A.O., 1962a, Surface waters of Elk Creek basin in southwestern Oklahoma: U.S. Geological Survey Open-File Report 63-138, 18 p.

$-1962 b$, Surface waters of Otter Creek basin in southwestern Oklahoma, with $a$ section on Chemical quality of surface water, by J.J. Murphy: U.S. Geological Survey Open-File Report 62-155, 37 p.

1963a, Surface water of Muddy Boggy River basin in south-central Oklahoma, with a section on Quality of water, by T.R. Cummings: U.S. Geological Survey Open-File Report 63-148, 71 p.

1963b, Surface water of Little River basin in southeastern Oklahoma, with a section on Quality of water, by R.P. Orth: U.S. Geological Survey Open-File Report 63-151, $66 \mathrm{p}$.
Westfall, A.O., and Patterson, J.L., 1964, Floods in Oklahoma, magnitude and frequency: U.S. Geological Survey Open-File Report 64-170, 105 p.

Wood, P.R., 1965a, Records of ground-water levels and effects of pumping in the Ardmore well-field area, Carter County, Oklahoma: U.S. Geological Survey Open-File Report 65-176, $14 \mathrm{p}$.

$1965 b$, Ground-water levels in observation wells in Oklahoma, 1963-64: U.S. Geological Survey Open-File Report 65-184, $82 \mathrm{p}$.

Wood, P.R., and Moeller, M.D., 1964, Groundwater levels in observation wells in Oklahoma, 1961-62: U.S. Geological Survey Open-File Report 64-169, 119 p.

\section{Water-Resources Investigations Reports}

Water-Resources Investigations Reports are of an interpretive nature and are made available to the public outside the formal USGS publications series.

Bingham, R.H., Bergman, D.L., and Thomas, W.O., Jr., 1974, Flood of October 1973 in Enid and vicinity, north-central Oklahoma: U.S. Geological Survey Water-Resources Investigations 27-74, scale 1:250, 000 , $1: 126,720,2$ sheets.

Christenson, S.C., 1983, Numerical simulation of the alluvium and terrace aquifer along the North Canadian River from Canton Lake to Lake Overholser, central Oklahoma: U.S. Geological Survey Water Resources Investigations Report 83-4076, $36 \mathrm{p}$.

Feder, G.L., and Krothe, N.C., 1981, Results of a reconnaissance water-quality sampling program of the Ogallala aquifer in Colorado, Kansas, Nebraska, Oklahoma, South Dakota, and Texas: U.S. Geological Survey Water-Resources Investigations 81-65, $7 \mathrm{p}$. 
Hart, D.L., Jr., Hoffman, G.L., and Goemaat, R.L., 1976, Geohydrology of the Oklahoma Panhandle, Beaver, Cimarron, and Texas Counties: U.S. Geological Survey WaterResources Investigation 25-75, $62 \mathrm{p}$.

Havens, J.S., 1982a, Altitude and configuration of the 1980 water table in the High Plains regional aquifer, northwestern Oklahoma: U.S. Geological Survey WaterResources Investigations Open-File Report 81-100, scale 1:250,000, 2 sheets.

$1982 \mathrm{~b}$, Altitude and configuration of the predevelopment water table in the High Plains regional aquifer, northwestern Oklahoma: U.S. Geological Survey WaterResources Investigations Open-File Report 81-275, scale 1:250,000, 2 sheets.

1982c, Saturated thickness of the High Plains regional aquifer in 1980, northwestern Oklahoma: U.S. Geological Survey Water-Resources Investigations Open-File Report 81-760, scale 1:250,000, 2 sheets.

1982d, Generalized altitude and configuration of the base of the High Plains regional aquifer, northwestern Oklahoma: U.S. Geological Survey Water-Resources Investigations Open-File Report 81-1117, scale 1:250,000, 2 sheets.

1983, Water-level changes in the High Plains regional aquifer, northwestern Oklahoma, predevelopment to 1980: U.S. Geological Survey Water-Resources Investigations Report 83-4073, scale 1:500,000, 1 sheet.

-1989 , Geohydrology of the alluvial and terrace deposits of the North Canadian River from Oklahoma City to Eufaula Lake, central Oklahoma: U.S. Geological Survey Water-Resources Investigations Report 884234, 32 p., 12 plates.

Havens, J.S., and Christenson, S.C., 1983, Numerical simulation of the High Plains regional aquifer, northwestern Oklahoma:
U.S. Geological Survey Water-Resources Investigations Report 83-4269, 27 p.

Heimann, D.C., and Tortorelli, R.L., 1988, Statistical summaries of streamflow records in Oklahoma in parts of Arkansas, Kansas, Missouri, and Texas through 1984: U.S. Geological Survey Water-Resources Investigations Report 87-4205, 387 p.

Heimes, F.J., and Luckey, R.R., 1982, Method for estimating historical irrigation requirements from ground water in the High Plains in parts of Colorado, Kansas, Nebraska, New Mexico, Oklahoma, South Dakota, Texas, and Wyoming: U.S. Geological Survey Water-Resources Investigations Report, 82-40, 64 p.

Krothe, N.C., and Oliver, J.W., 1982, Sulfur isotopic composition and water chemistry in water from the High Plains aquifer, Oklahoma Panhandle and southwestern Kansas: U.S. Geological Survey WaterResources Investigations 82-12, 27 p.

Kurklin, J.K., 1985, Water quality in the Blue Creek arm of Lake Eufaula and Blue Creek, Oklahoma, March-October 1978: U.S. Geological Survey Water-Resources Investigations Report 85-4039, 91 p.

1990, Water quality in Gaines Creek and Gaines Creek arm of Eufaula Lake, Oklahoma: U.S. Geological Survey WaterResources Investigations Report 86-4169, $97 \mathrm{p}$.

Marcher, M.V., Bergman, D.L., Slack, L.J., and Blumer, S.P., 1984, Hydrology of Area 41, Western Region, Interior Coal Province, Oklahoma and Arkansas: U.S. Geological Survey Water-Resources Investigations Open-File Report 84-129, 86 p.

Marcher, M.V., Bergman, D.L., Stoner, J.D., and Blumer, S.P., 1981, Preliminary appraisal of the hydrology of the Blocker area, Pittsburg County, Oklahoma: U.S. Geological Survey Water-Resources 
Investigations Open-File Report 81-1187, $48 \mathrm{p}$.

1983a, Preliminary appraisal of the hydrology of the Rock Island area, Le Flore County, Oklahoma: U.S. Geological Survey Water-Resources Investigations Report 83-4013, 35 p.

1983b, Preliminary appraisal of the hydrology of the Red Oak area, Latimer County, Oklahoma: U.S. Geological Survey Water-Resources Investigations Report 83-4166, 44 p.

Marcher, M.V., Huntzinger, T.L., Stoner, J.D., and Blumer, S.P., 1983, Preliminary appraisal of the hydrology of the Stigler area, Haskell County, Oklahoma: U.S. Geological Survey Water-Resources Investigations Report 82-4099, 37 p.

Marcher, M.V., Kenny, J.F., and others, 1984, Hydrology of Area 40, Western Region, Interior Coal Province, Kansas, Oklahoma, and Missouri: U.S. Geological Survey Water-Resources Investigations Open-File Report 83-266, 97 p.

Morton, R.B., 1992, Simulation of groundwater flow in the Antlers aquifer in southeastern Oklahoma and northeastern Texas: U.S. Geological Survey Water-Resources Investigations Report 88-4208, 22 p.

Parkhurst, R.S., and Christenson, S.C., 1987, Selected chemical analyses of water from formations of Mesozoic and Paleozoic age in parts of Oklahoma, northern Texas, and Union County, New Mexico: U.S. Geological Survey Water-Resources Investigations Report 86-4355, 222 p.

Reed, J.E., 1982, Preliminary projections of the effects of chloride-control structures on the Quaternary aquifer at Great Salt Plains, Oklahoma: U.S. Geological Survey WaterResources Investigations 80-120, 45 p.

Sauer, V.B., 1974a, Flood characteristics of Oklahoma streams: U.S. Geological Sur- vey Water-Resources Investigations 52-73, $301 \mathrm{p}$.

1974b, An approach to estimating flood frequency for urban areas in Oklahoma: U.S. Geological Survey WaterResources Investigations 23-74, $10 \mathrm{p}$.

Scott, J.C., 1989, A computerized data-base system for land-use and land-cover data collected at ground-water sampling sites in the pilot National Water-Quality Assessment program: U.S. Geological Survey Water-Resources Investigations Report 894172, $139 \mathrm{p}$.

1990a, A statistical processor for analyzing simulations made using the modular finite-difference ground-water flow model: U.S. Geological Survey Water-Resources Investigations Report 89-4159, 218 p.

1990b, Computerized stratified random site-selection approaches for design of a ground-water-quality sampling network: U.S. Geological Survey Water-Resources Investigations Report 90-4101, 109 p.

1991, Computer software for converting ground-water and water-quality data from the National Water Information System for use in a geographic information system: U.S. Geological Survey WaterResources Investigations Report 90-4200, $55 \mathrm{p}$.

Slack, L.J., 1983, Hydrology of an abandoned coal-mining area near McCurtain, Haskell County, Oklahoma: U.S. Geological Survey Water-Resources Investigations Report 83-4202, $117 \mathrm{p}$.

Stoner, J.D., 1981a, Water type and suitability of Oklahoma surface waters for public supply and irrigation, Part 1; Arkansas River mainstem and Verdigris, Neosho, and Illinois River basins through 1978: U.S. Geological Survey Water-Resources Investigations 81-33, $297 \mathrm{p}$. 
$-1981 b$, Water type and suitability of Oklahoma surface waters for public supply and irrigation, Part 2; Salt Fork Arkansas and Cimarron River basins through 1978: U.S. Geological Survey Water-Resources Investigations $81-39,150 \mathrm{p}$.

1981c, Water type and suitability of Oklahoma surface waters for public supply and irrigation, Part 3; Canadian, North Canadian, and Deep Fork River basins through 1979: U.S. Geological Survey Water-Resources Investigations 81-80, $210 \mathrm{p}$.

1982a, Water type and suitability of Oklahoma surface waters for public supply and irrigation, Part 4; Red River mainstem and North Fork Red River through 1979: U.S. Geological Survey Water-Resources Investigations 82-9, $235 \mathrm{p}$.

$1982 b$, Water type and suitability of Oklahoma surface waters for public supply and irrigation, Part 5; Washita River basin through 1979: U.S. Geological Survey Water-Resources Investigations 82-29, $150 \mathrm{p}$.

1984, Estimate of self-supplied domestic water use in Oklahoma during 1980: U.S. Geological Survey Water-Resources Investigations Report 83-4223, 20 p.

1985, Reported withdrawals and estimated use of water in Oklahoma during 1982: U.S. Geological Survey WaterResources Investigations Report 85-4084, $96 \mathrm{p}$.

Thomas, W.O., Jr., 1976, Techniques for estimating flood depths for Oklahoma streams: U.S. Geological Survey WaterResources Investigations 2-76, $170 \mathrm{p}$.

Thomas, W.O., Jr., and Corley, R.K., 1973, 1971-72 Floods on Glover Creek and Little River in southeastern Oklahoma: U.S. Geological Survey Water-Resources
Investigations $\quad 5-73$, scale $1: 24,000$, 2 sheets.

1977, Techniques for estimating flood discharges for Oklahoma streams: U.S. Geological Survey Water-Resources Investigations 77-54, $170 \mathrm{p}$.

Tortorelli, R.L., and Bergman, D.L., 1984, Techniques for estimating flood peak discharges for unregulated streams and streams regulated by small floodwater retarding structures in Oklahoma: U.S. Geological Survey Water-Resources Investigations Report 84-4358, 85 p.

Weeks, J.B., 1978, Plan of study for the High Plains regional aquifer systems analysis in parts of Colorado, Kansas, New Mexico, Oklahoma, South Dakota, Texas, and Wyoming: U.S. Geological Survey WaterResources Investigations 78-70, 28 p.

\section{Federal Emergency Management Flood Insurance Studies}

FEMA studies delineate flood-prone areas and are used by community planners.

Bergman, D.L., 1980a, City of Sallisaw, Oklahoma: Washington D.C., Federal Emergency Management Agency Flood Insurance Study, community number $400199,23 \mathrm{p}$.

1980b, City of Edmond, Oklahoma: Washington D.C., Federal Emergency Management Agency Flood Insurance Study, community number $400252,41 \mathrm{p}$.

1980c, City of the Village, Oklahoma: Washington D.C., Federal Emergency Management Agency Flood Insurance Study, community number $400420,15 \mathrm{p}$.

1982, City of Nichols Hills, Oklahoma: Washington D.C., Federal Emergency Management Agency Flood Insurance Study, community number $400423,15 \mathrm{p}$. 
Bergman, D.L., and Walton, C., 1979, City of Duncan, Oklahoma: Washington D.C., Federal Emergency Management Agency Flood Insurance Study, community number 400202, 24 p.

Corley, R.K., 1980, City of Ponca City, Oklahoma: Washington D.C., Federal Emergency Management Agency Flood Insurance Study, community number 400080, $23 \mathrm{p}$.

Huntzinger, T.L., 1979a, City of Enid, Oklahoma: Washington D.C., Federal Emergency Management Agency Flood Insurance Study, community number 400062, $31 \mathrm{p}$.

1979b, City of McAlester, Oklahoma: Washington D.C., Federal Emergency Management Agency Flood Insurance Study, community number $400170,22 \mathrm{p}$.

1980a, City of Mustang, Oklahoma: Washington D.C., Federal Emergency Management Agency Flood Insurance Study, community number $400409,15 \mathrm{p}$.

1980b, Town of Nicoma Park, Oklahoma: Washington D.C., Federal Emergency Management Agency Flood Insurance Study, community number 400424, $15 \mathrm{p}$.

1981a, Town of North Enid, Oklahoma: Washington D.C., Federal Emergency Management Agency Flood Insurance Study, community number 400425, $14 \mathrm{p}$.

$1981 b$, City of Choctaw, Oklahoma: Washington D.C., Federal Emergency Management Agency Flood Insurance Study, community number $400357,23 \mathrm{p}$.

1981c, City of Midwest City, Oklahoma: Washington D.C., Federal Emergency Management Agency Flood Insurance Study, community number 400405, $21 \mathrm{p}$.
Huntzinger, T.L., and Tortorelli, R.L., 1980a, City of Spencer, Oklahoma: Federal Emergency Management Agency Flood Insurance Study, community number 400412, $15 \mathrm{p}$.

$1980 \mathrm{~b}$, City of Warr Acres, Oklahoma: Washington D.C., Federal Emergency Management Agency Flood Insurance Study, community number $400449,13 \mathrm{p}$.

1981a, Town of Jones, Oklahoma: Washington D.C., Federal Emergency Management Agency Flood Insurance Study, community number $400141,20 \mathrm{p}$.

1981b, Town of Valley Brook, Oklahoma: Washington D.C., Federal Emergency Management Agency Flood Insurance Study, community number $400445,13 \mathrm{p}$.

Huntzinger, T.L., Tortorelli, R.L., and Bergman, D.L., 1982, City of Oklahoma City, Oklahoma: Washington D.C., Federal Emergency Management Agency Flood Insurance Study, community number 405378, $194 \mathrm{p}$.

Tortorelli, R.L., 1982, Town of Piedmont, Oklahoma: Washington D.C., Federal Emergency Management Agency Flood Insurance Study, community number 400027, $17 \mathrm{p}$.

1988, Limited detail flood insurance study, City of Tishomingo, Johnston County, Oklahoma: Washington, D.C., Federal Emergency Management Agency Flood Insurance Study, community number 400077, 11p.

1989, Limited detail flood insurance study, Town of Pocola, Le Flore County, Oklahoma: Washington, D.C., Federal Emergency Management Agency Flood Insurance Study, community number 400432, 11p. 
1990, Limited detail flood insurance study, Bryan County, and incorporated areas: Washington, D.C., Federal Emergency Management Agency Flood Insurance Study, community number 400482, $22 \mathrm{p}$.

Tortorelli, R.L., Huntzinger, T.L., and Bergman, D.L., 1982, Oklahoma County, Oklahoma: Washington D.C., Federal Emergency Management Agency Flood Insurance Study, community number 400466, 21 p.

\section{Water-Resources Data Reports}

Water-resources data reports document hydrologic data gathered from the U.S. Geological Survey's surfacewater and ground-water data-collection networks.

Blazs, R.L., Boyle, D.L., Coffey, T.E., Walters, D.M., and White, D.K., 1990, Water resources data for Oklahoma, water year 1989: U.S. Geological Survey Water-Data Report OK-89-1, 522 p.

Blazs, R.L., Walters, D.M., Coffey, T.E., White, D.K., and Boyle, D.L., 1991, Water resources data for Oklahoma, water year 1990: U.S. Geological Survey Water-Data Report OK-90-1, 517 p.

Blazs, R.L., Walters, D.M., Coffey, T.E., White, D.K., Boyle, D.L., and Kerestes, J.F., 1992, Water resources data for Oklahoma, water year 1991: U.S. Geological Survey Water-Data Report OK-91-1, 449 p.

Blazs, R.L., Walters, D.M., Coffey, T.E., White, D.K., Boyle, D.L., and Kerestes, J.F., 1993a, Water resources data for Oklahoma, water year 1992, Volume 1, Arkansas River basin: U.S. Geological Survey Water-Data Report OK-92-1, 524 p.

Blazs, R.L., Walters, D.M., Coffey, T.E., White, D.K., Boyle, D.L., and Kerestes, J.F., 1993b, Water resources data for Oklahoma, water year 1992, Volume 1, Arkan- sas River basin: U.S. Geological Survey Water-Data Report OK-92-1, 239 p.

Hauth, L.D., Kurklin, J.K., and Walters, D.M., 1985, Water resources data for Oklahoma, water year 1983: U.S. Geological Survey Water-Data Report OK-83-1, 286 p.

1986, Water resources data, Oklahoma, water year 1984: U.S. Geological Survey Water-Data Report OK-84-1, 302 p.

1988, Water resources data, Oklahoma, water year 1986: U.S. Geological Survey Water-Data Report OK-86-1, 316 p.

Hauth, L.D., Kurklin, J.K., Walters, D.M., and Coffey, T.E., 1987, Water resources data, Oklahoma, water year 1985: U.S. Geological Survey Water-Data Report OK-85-1, 302 p.

Hauth, L.D., Kurklin, J.K., Walters, D.M., and Ferree, D.M., 1984, Water resources data, Oklahoma, water year 1982: U.S. Geological Survey Water-Data Report OK-82-1, 336 p.

Hauth, L.D., Walters, D.M., Coffey, T.E., and White, D.K., 1989, Water resources data, Oklahoma, water year 1987: U.S. Geological Survey Water-Data Report OK-87-1, $324 \mathrm{p}$.

1990, Water resources data, Oklahoma, water year 1988: U.S. Geological Survey Water-Data Report OK-88-1, 326 p.

U.S. Geological Survey, 1961-64, Surfacewater records of Oklahoma. (One volume for each year).

1964, Quality-of-water records of Oklahoma, 62 p.

1965-74, Water resources data for Oklahoma-Part 1, Surface-water records; Part 2, Water-quality records. (One volume of each for each year). 
1976, Water resources data for Oklahoma, water year 1975: U.S. Geological Survey Water-Data Report OK-75-1, $528 \mathrm{p}$.

1977a, Water resources data for Oklahoma, water year 1976, Volume 1, Arkansas River basin: U.S. Geological Survey Water-Data Report OK-76-1, 513 p.

$1977 b$, Water resources data for Oklahoma, water year 1976, Volume 2, Red River basin: U.S. Geological Survey Water-Data Report OK-76-2, 216 p.

1978a, Water resources data for Oklahoma, water year 1977, Volume 1, Arkansas River basin: U.S. Geological Survey Water-Data Report OK-77-1, 542 p.

$1978 b$, Water resources data for Oklahoma, water year 1977, Volume 2, Red River basin: U.S. Geological Survey Water-Data Report OK-77-2, 235 p.

1979a, Water resources data for Oklahoma, water year 1978, Volume 1, Arkansas River basin: U.S. Geological Survey Water-Data Report OK-78-1, 523 p.

$1979 b$, Water resources data for Oklahoma, water year 1978, Volume 2, Red River basin: U.S. Geological Survey Water-Data Report OK-78-2, 249 p.

1981a, Water resources data for Oklahoma, water year 1979, Volume 1, Arkansas River basin: U.S. Geological Survey Water-Data Report OK-79-1, 629 p.

$1981 b$, Water resources data for Oklahoma, water year 1979, Volume 2, Red River basin: U.S. Geological Survey Water-Data Report OK-79-2, 249 p.

1982, Water resources data for Oklahoma, water year 1980, Volume 1: U.S. Geological Survey Water-Data Report OK-80-1, 613 p.

1983, Water resources data-Oklahoma, water year 1981: U.S. Geological
Survey Water-Data Report OK-81-1, 546 p.

\section{Circulars}

Circulars present technical or nontechnical information of wide popular interest in a format designed for distribution at no cost to the public. They are published to disseminate administrative information or important scientific information of an ephemeral nature.

Irwin, J.H., and Morton, R.B., 1969, Hydrogeologic information on the Glorieta Sandstone and Ogallala Formation in the Oklahoma Panhandle and adjoining areas as related to underground waste disposal: U.S. Geological Survey Circular 630, 26 p.

Mosier, E.L., and Bullock, J.H., Jr., 1988, Review of the general geology and solidphase geochemical studies in the vicinity of the Central Oklahoma aquifer: U.S. Geological Survey Circular 1019, 18 p.

\section{Annual Reports}

Annual reports by the Director of the U.S. Geological Survey were published from 1880 through 1932. Since 1933 a condensed form has been included in the annual report of the Secretary of the Interior.

Johnson, W.D., 1901, The High Plains and their utilization: U.S. Geological Survey Twenty-first Annual Report, IV, p.601741.

1902, The High Plains and their utilization: U.S. Geological Survey Twenty-second Annual Report, IV, p. 631-639.

\section{Miscellaneous Reports and Maps}

Miser, H.D., 1954, Geologic map of Oklahoma: Oklahoma Geological Survey and U.S. Geological Survey, scale 1:500,000.

U.S. Geological Survey, 1976, Hydrologic Unit Map of Oklahoma-1974: Scale 1:500,000, 1 sheet.

1977, Water-resources investigations in Oklahoma, 1976: U.S. Geological Survey miscellaneous report, $6 \mathrm{p}$. 


\section{OKLAHOMA WATER RESOURCES BOARD}

\section{Bulletins}

Oklahoma Water Resources Board Bulletins present data and results of hydrologic, water-quality, and areal studies in Oklahoma.

Barclay, J.E., and Burton, L.C., 1953, Groundwater resources of the terrace deposits and alluvium of western Tillman County, Oklahoma: Oklahoma Planning and Resources Board Division of Water Resources Bulletin $12,71 \mathrm{p}$.

Burton, L.C., 1965, Ground water in terrace deposits of central Beckham County, Oklahoma: Oklahoma Water Resources Board Bulletin 25, $30 \mathrm{p}$.

Cummings, T.R., 1963, Chemical character of surface waters in Oklahoma 1957-58: Oklahoma Water Resources Board Bulletin $19,165 \mathrm{p}$.

1964, Chemical character of surface waters in Oklahoma 1958-59: Oklahoma Water Resources Board Bulletin 20, 133 p.

1965a, Chemical character of surface waters in Oklahoma 1960-61: Oklahoma Water Resources Board Bulletin 23, 178 p.

$1965 \mathrm{~b}$, Chemical character of surface waters in Oklahoma 1961-62: Oklahoma Water Resources Board Bulletin 24, 203 p.

1966a, Chemical character of surface waters in Oklahoma 1959-60: Oklahoma Water Resources Board Bulletin 22, 167 p.

1966b, Chemical character of surface waters in Oklahoma 1962-63: Oklahoma Water Resources Board Bulletin 30, 200 p.

Dover, T.B., 1953a, Chemical character of surface waters in Oklahoma 1950-51: Oklahoma Planning and Resources Board Division of Water Resources Bulletin 7, $88 \mathrm{p}$.
$1953 \mathrm{~b}$, Chemical character of public water supplies of Oklahoma 1953: Oklahoma Planning and Resources Board Division of Water Resources Bulletin 8, $47 \mathrm{p}$.

1954, Chemical character of surface waters of Oklahoma 1951-52: Oklahoma Planning and Resources Board Division of Water Resources Bulletin 10, 115 p.

1956, Chemical character of surface waters of Oklahoma 1953-54: Oklahoma Planning and Resources Board Division of Water Resources Bulletin 14, 141 p.

1958, Chemical character of surface waters of Oklahoma 1954-55: Oklahoma Water Resources Board Bulletin 15, 117 p.

1959, Chemical character of surface waters of Oklahoma 1955-56: Oklahoma Water Resources Board Bulletin 16, 144 p.

Dover, T.B., and Murphy, J.J., 1955, A reconnaissance of the chemical and physical quality of Pryor Creek in the vicinity of Pryor, Oklahoma: Oklahoma Planning and Resources Board Division of Water Resources Bulletin 13, 32 p.

Gilbert, C.R., 1959, Hydrologic and physical data for Sandstone Creek watershed in western Oklahoma 1951-56: Oklahoma Water Resources Board Bulletin 17, 124 p.

Hart, D.L., Jr., 1965, Ground water in the alluvial deposits of the Washita River between Clinton and Anadarko, Oklahoma: Oklahoma Water Resources Board Bulletin 26, $23 \mathrm{p}$.

Hollowell, J.R., 1965a, Ground water in the alluvium of Otter Creek basin, Oklahoma: Oklahoma Water Resources Board Bulletin $27,15 \mathrm{p}$.

$1965 \mathrm{~b}$, Ground water in the alluvium of Elk Creek basin, Oklahoma: Oklahoma Water Resources Board Bulletin 28, 12 p.

Murphy, J.J., 1955, Chemical character of surface waters of Oklahoma 1952-53: Okla- 
homa Planning and Resources Board Division of Water Resources Bulletin 11, $128 \mathrm{p}$.

Pate, C.O., Murphy, J.J., and Orth, R.P., 1961, Chemical character of surface waters of Oklahoma 1956-57: Oklahoma Water Resources Board Bulletin 18, 138 p.

Reed, E.W., Mogg, J.L., Barclay, J.E., and Peden, G.H., 1952, Ground-water resources of the terrace deposits along the northeast side of the Cimarron River in Alfalfa, Garfield, Kingfisher, and Major Counties, Oklahoma: Oklahoma Planning and Resources Board Division of Water Resources Bulletin 9, 101 p.

Steele, C.E., and Barclay, J.E., 1965, Groundwater resources of Harmon County and adjacent parts of Greer and Jackson Counties, Oklahoma: Oklahoma Water Resources Board Bulletin 29, 96 p.

Walling, I.W., 1949, Chemical character of surface waters in the Washita River basin of Oklahoma, 1946-47: Oklahoma Planning and Resources Board Division of Water Resources Bulletin 4, 31 p.

1952, Chemical character of surface waters in Oklahoma 1949-50: Oklahoma Planning and Resources Board Division of Water Resources Bulletin 6, 70 p.

Walling, I.W., Schoff, S.L., and Dover, T.B., 1951, Chemical character of surface waters in Oklahoma 1946-49: Oklahoma Planning and Resources Board Division of Water Resources Bulletin 5, $180 \mathrm{p}$.

Wood, P.R., and Stacy, B.L., 1965, Geology and ground-water resources of Woodward County, Oklahoma: Oklahoma Water Resources Board Bulletin 21, 114 p.

\section{Hydrologic Investigation}

Oklahoma Water Resources Board Hydrologic Investigations contain hydrogeologic information on areas in Oklahoma.
Wickersham, Ginia, 1979, Ground water resources of the southern part of the GarberWellington ground water basin, in Cleveland and southern Oklahoma Counties and parts of Pottawatomie County, Oklahoma: Oklahoma Water Resources Board Hydrologic Investigations Publication 86, 3 sheets.

\section{Miscellaneous Reports}

Laine, L.L., 1940(?), Provisional report on flood of September 1940, and miscellaneous discharge measurements, in Dam failure at Cleveland caused by storm of September 4, 1940: Oklahoma Planning and Resources Board Division of Water Resources, p. 7-18.

Oklahoma Water Resources Board, 1975, Salt water detection in the Cimarron terrace, Oklahoma: U.S. Environmental Protection Agency Ecological Research Series EPA660/3-74-033, $166 \mathrm{p}$.

Reed, E.W., Oakland, G.L., and Jacobsen, C.L., 1945, Oklahoma water: Oklahoma Planning and Resources Board Division of Water Resources, $145 \mathrm{p}$.

U.S. Geological Survey, 1945, Oklahoma water-Quantity, occurrence, and quality of surface and ground water: Oklahoma Planning and Resources Board, $145 \mathrm{p}$.

\section{OKLAHOMA GEOLOGICAL SURVEY}

\section{Bulletins}

Oklahoma Geological Survey Bulletins are comprehensive or detailed reports on geologic, hydrologic, paleontologic, or areal studies in Oklahoma.

Bingham, R.H., 1979, Water Resources [of Noble County, Oklahoma], in Shelton, J.W., 1979, Geology and mineral resources of Noble County, Oklahoma: Oklahoma Geological Survey Bulletin 128, $66 \mathrm{p}$. 
Davis, L.V., 1955, Geology and water resources of the Grady and northern Stephens Counties, Oklahoma: Oklahoma Geological Survey Bulletin 73, 184 p.

1960, Geology and ground-water resources of southern McCurtain County, Oklahoma: Oklahoma Geological Survey Bulletin 86, $108 \mathrm{p}$.

Hart, D.L., Jr., 1978, Ground water in Custer County, in Fay, R.O., 1978, Geology and mineral resources (exclusive of petroleum) of Custer County, Oklahoma: Oklahoma Geological Survey Bulletin 114, 88 p.

Marine, I.W., and Schoff, S.L., 1962, Groundwater resources of Beaver County, Oklahoma: Oklahoma Geological Survey Bulletin $97,74 \mathrm{p}$.

Mogg, J.L., Schoff, S.L., and Reed, E.W., 1960, Ground water resources of Canadian County, Oklahoma: Oklahoma Geological Survey Bulletin 7, 112 p.

Motts, W.S., 1963, Water resources of Okmulgee County, part 2 of Oklahoma Geological Survey, Geology and water resources of Okmulgee County, Oklahoma: Oklahoma Geological Survey Bulletin 91, p. 5-6, 81123.

Schoff, S.L., 1939, Geology and ground-water resources of Texas County, Oklahoma: Oklahoma Geological Survey Bulletin 59, $248 \mathrm{p}$.

1943, Geology and ground-water resources of Cimarron County, Oklahoma, with a section on Mesozoic stratigraphy by J.W. Stovall: Oklahoma Geological Survey Bulletin 64, 317 p.

Schoff, S.L., Reed, E.W., and Branson, C.C., 1955, Geology and ground-water resources of Ottawa County, Oklahoma: Oklahoma Geological Survey Bulletin 72, 203 p.

Warren, J.H., 1952, Water resources of Tulsa County, in Oakes, M.C.., Geology and mineral resources of Tulsa County, Oklahoma:
Oklahoma Geological Survey Bulletin 69, p. 140-155.

\section{Circulars}

Oklahoma Geological Survey Circulars contain symposia proceedings and less comprehensive or detailed geologic, hydrologic, or areal studies in Oklahoma.

D’Lugosz, J.J., McClaflin, R.G., and Marcher, M.V., 1986, Geohydrology of the VamoosaAda aquifer, east-central Oklahoma: Oklahoma Geological Survey Circular 87, $42 \mathrm{p}$.

Fairchild, R.W., Hanson, R.L., and Davis, R.E., 1990, Hydrology of the Arbuckle Mountains area, south-central Oklahoma: Oklahoma Geological Survey Circular 91, 112 p., 2 plates, scale 1:100,000.

Hart, D.L., Jr., and Davis, R.E., 1981, Geohydrology of the Antlers aquifer (Cretaceous), southeastern Oklahoma: Oklahoma Geological Survey Circular 81, 33 p.

Havens, J.S., 1983, Reconnaissance of ground water in the vicinity of the Wichita Mountains, southwestern Oklahoma: Oklahoma Geological Survey Circular 85, 13 p.

Morton, R.B., 1986, Effects of brine on the chemical quality of water in parts of Creek, Lincoln, Okfuskee, Payne, Pottawatomie, and Seminole Counties, Oklahoma: Oklahoma Geological Survey Circular 89, 38 p.

Playton, S.J., Davis, R.E., and McClaflin, R.G., 1980, Chemical quality of water in abandoned zinc mines in northeastern Oklahoma and southeastern Kansas: Oklahoma Geological Survey Circular 82, 49 p. [Also released as USGS OFR 78-294.]

Schoff, S.L., and Reed, E.W., 1951a, Groundwater resources of the Arkansas River flood plain near Fort Gibson, Muskogee County, Oklahoma: Oklahoma Geological Survey Circular 28, $55 \mathrm{p}$.

Tanaka, H.H., and Davis, L.V., 1963, Groundwater resources of the Rush Springs Sandstone in the Caddo County area, Oklahoma: 
Oklahoma Geological Survey Circular 61, $63 \mathrm{p}$.

Wood, P.R., and Burton, L.C., 1968, Groundwater resources of Cleveland and Oklahoma Counties, Oklahoma: Oklahoma Geological Survey Circular 71, 75 p.

\section{Mineral Reports}

Oklahoma Geological Survey Mineral Reports deal with the mineral resources of Oklahoma, including water.

Davis, L.V., 1950, Ground water in the Pond Creek basin, Caddo County, Oklahoma: Oklahoma Geological Survey Mineral Report 22, 23 p.

1953, Oil possibilities near Idabel, McCurtain County, Oklahoma: Oklahoma Geological Survey Mineral Report 23, 26 p.

Dott, R.H., 1942, Geology of Oklahoma ground-water supplies: Oklahoma Geological Survey Mineral Report 11, 26 p.

Jacobsen, C.L., and Reed, E.W., 1949, Ground-water supplies in the Oklahoma City area, Oklahoma: Oklahoma Geological Survey Mineral Report 20, 25 p.

Schoff, S.L., 1948, Ground-water irrigation in the Duke area, Jackson and Greer Counties, Oklahoma: Oklahoma Geological Survey Mineral Report 18, 8 p.

1949, Ground-water in Kingfisher County, Oklahoma: Oklahoma Geological Survey Mineral Report 19, 20 p.

1950 , Ground-water in the Cherokee area, Alfalfa County, Oklahoma: Oklahoma Geological Survey Mineral Report $21,17 \mathrm{p}$.

\section{Geologic Map}

Schoff, S.L., 1955, Map of ground-water reservoirs in Oklahoma: Oklahoma Geological Survey Geologic Map GM-2, scale 1:750,000, 1 sheet.

\section{Educational Publication}

Oklahoma Geological Survey Educational Publications are reports designed to bring quickly available and readily comprehensible information to the general public.

Marcher, M.V., 1972, Major sources of water in Oklahoma, in Johnson, K.S., and others, 1972, Geology and earth resources of Oklahoma, An atlas of maps and cross sections: Oklahoma Geological Survey Educational Publication 1, p. 8.

\section{Hydrologic Atlases}

Oklahoma Geological Survey Hydrologic Atlases present geologic and hydrologic information in an accessible and easily comparable format.

Bingham, R.H., and Bergman, D.L., 1980, Reconnaissance of the water resources of the Enid quadrangle, north-central Oklahoma: Oklahoma Geological Survey Hydrologic Atlas 7, 4 sheets, scale 1:250,000.

Bingham, R.H., and Moore, R.L., 1975, Reconnaissance of the water resources of the Oklahoma City quadrangle, central Oklahoma: Oklahoma Geological Survey Hydrologic Atlas 4, scale 1:250,000, 4 sheets.

Carr, J.E., and Bergman, D.L., 1976, Reconnaissance of the water resources of the Clinton quadrangle, west-central Oklahoma: Oklahoma Geological Survey Hydrologic Atlas 5, scale 1:250,000, 4 sheets.

Hart, D.L., Jr., 1974, Reconnaissance of the water resources of the Ardmore and Sherman quadrangles, southern Oklahoma: Oklahoma Geological Survey Hydrologic Atlas 3, scale 1:250,000, 4 sheets.

Havens, J.S., 1977, Reconnaissance of the water resources of the Lawton quadrangle, southwestern Oklahoma: Oklahoma Geological Survey Hydrologic Atlas 6, scale 1:250,000, 4 sheets. 
Marcher, M.V., 1969, Reconnaissance of the water resources of the Fort Smith quadrangle, east-central Oklahoma: Oklahoma Geological Survey Hydrologic Atlas 1, scale $1: 250,000,4$ sheets.

Marcher, M.V., and Bergman, D.L., 1983, Reconnaissance of the water resources of the McAlester and Texarkana quadrangles, southeastern Oklahoma: Oklahoma Geological Survey Hydrologic Atlas 9, scale $1: 250,000,4$ sheets.

Marcher, M.V., and Bingham, R.H., 1971, Reconnaissance of the water resources of the Tulsa quadrangle, northeastern Oklahoma: Oklahoma Geological Survey Hydrologic Atlas 2, scale 1:250,000, 4 sheets.

Morton, R.B., 1980, Reconnaissance of the water resources of the Woodward quadrangle, northwest Oklahoma: Oklahoma Geological Survey Hydrologic Atlas 8, scale $1: 250,000,4$ sheets.

\section{The Hopper and Oklahoma Geology Notes}

The Oklahoma Geological Survey Hopper, later retitled Oklahoma Geology Notes, brings information on a wide range of geologic, hydrologic, paleontologic, mineralogic, and earth sciences subjects to the general public. It also contains abstracts of meetings and symposia.

Bingham, R.H., 1969a, Springs in northeastern Oklahoma [abs.]: Oklahoma Geological Survey Oklahoma Geology Notes, v. 29, no.1, p. 19.

1969b, Springs in the Ozark Region, northeastern Oklahoma: Oklahoma Geological Survey Oklahoma Geology Notes, v. 29 , no. 6 , p. $135-145$.

Blumer, S.P., and Slack, L.J., 1986, Physical and chemical characteristics of water in coal-mine ponds, eastern Oklahoma: Oklahoma Geological Survey Oklahoma Geology Notes, v. 46 , no. 4 , p. $128-134$.
Davis, L.V., 1958a, Ground water in the Arbuckle and Simpson Groups in the Arbuckle Mountains, Oklahoma: Oklahoma Geological Survey Oklahoma Geology Notes, v. 18 , no. 10 , p. 152-157.

1958b, Oklahoma's underground water: Oklahoma Geological Survey Oklahoma Geology Notes, v. 18 , no. 12, p. 189202.

Dott, R.H., 1948, Ground-water supplies in Oklahoma and their development: Oklahoma Geological Survey, The Hopper, v. 8, part 1, July, p. 63-68, part 2, August, p. 7174, part 3, September, p. 81-89.

Fairchild, R.W., 1984, Springs in the Arbuckle Mountain area, south-central Oklahoma: Oklahoma Geological Survey Oklahoma Geology Notes, v. 44, no. 1, p. 4-11.

Hart, D.L., Jr., 1961, Fluctuations of water levels in wells: Oklahoma Geological Survey Oklahoma Geology Notes, v. 21, no. 2, p. $41-47$.

Hauth, L.D., 1985, An overview of hydrologic-data collection by the U.S. Geological Survey in Oklahoma: Oklahoma Geological Survey Oklahoma Geology Notes, v. 45, no. 4 , p. 149-161.

Havens, J.S., 1985, Water-level changes in the Ogallala aquifer, northwestern Oklahoma: Oklahoma Geological Survey Oklahoma Geology Notes, v. 45, no. 5, p. 205-210.

Mosier, E.L., Breit, G.N., Schlottmann, J.L., and Papp, C.S.E., 1992, Processes responsible for large concentrations of $\mathrm{As}, \mathrm{Cr}, \mathrm{Se}$, $\mathrm{U}$, and $\mathrm{V}$ in water produced from the Central Oklahoma aquifer [abs.]: Geological Society of America, Abstracts with Programs, v. 22, no. 7, p. A61.

Reed, E.W., 1949, Unusual fluctuations in Rush Springs wells: Oklahoma Geological Survey, The Hopper, v. 9, no. 7, p. 69-70.

1950 , Increased use of ground water for irrigation in the Duke area, Oklahoma: 
Oklahoma Geological Survey, The Hopper, v. 10 , p. 86-90.

Reed, E.W., and Schoff, S.L., 1947, Groundwater storage increases in Tillman County, Oklahoma: Oklahoma Geological Survey, The Hopper, v. 7, p. 77-80.

Schoff, S.L., 1942, Geology and ground-water resources of Beaver County, Oklahoma: Oklahoma Geological Survey, The Hopper, v. 2, no. 10, p. 94-97.

1948, Ground-water at high stage in Oklahoma Panhandle: Oklahoma Geological Survey, The Hopper, v. 8, no. 8, p. 74 76.

1950, Deep well irrigation in Oklahoma Panhandle: Oklahoma Geological Survey, The Hopper, v. 10, no. 8, p. 76.

1953, Ground-water pumpage and water levels in Oklahoma: Oklahoma Geological Survey, The Hopper, v. 13, no. 912 , p. 51-57.

1956, Laverne formation: Oklahoma Geological Survey Oklahoma Geology Notes, v. 16, no. 1, p. 3-5.

Scott, J.C., 1984, Use of minicomputers in water-resources investigations: Oklahoma Geological Survey Oklahoma Geology Notes, v. 44, no. 6, p. 188-89.

Tanaka, H.H., 1958, Changes in ground-water levels in Oklahoma during 1957: Oklahoma Geological Survey Oklahoma Geology Notes, v. 18, no. 3, p. 57.

U.S. Geological Survey, 1974, Summary of October 1973 rainstorm, Enid and vicinity, north-central Oklahoma: Oklahoma Geological Survey Oklahoma Geology Notes, v. 34, no. 6, p. 209-212.

Ward, P.E., 1961a, Salt springs in Oklahoma: Oklahoma Geological Survey Oklahoma Geology Notes, v. 21, no. 3, p. 81-84.

1961b, Shallow halite deposits in northern Woodward and southern Woods
Counties, Oklahoma: Oklahoma Geological Survey Oklahoma Geology Notes, v. 21, no. 10 , p. $275-277$.

\section{Special Publication}

The Oklahoma Geological Survey Special Publications series is designed to bring timely information to the public quickly and economically.

Slack, L.J., and Blumer, S.P., 1987, Physical and chemical characteristics of water in coal-mine ponds, eastern Oklahoma: Oklahoma Geological Survey Special Publication $87-2,116 \mathrm{p}$.

\section{PROFESSIONAL SOCIETIES' ABSTRACTS AND JOURNAL ARTICLES}

Articles and abstracts in non-Geological Survey journals can be obtained from the author or purchased directly from the publisher.

Breit, G.N., Cast, M.E., and Stanton, M.R., 1992, Chromium redistribution within continental red beds: A function of pore-water chemistry: Proceedings of the 7th International Symposium on Water-Rock Interaction, Park City, Utah, 13-19 July 1992, Rotterdam, A.A. Balkema.

Christenson, S.C., 1982, Numerical simulation of the alluvium and terrace aquifer along the North Canadian River from Canton Lake to Lake Overholser, central Oklahoma [abs.]: Geological Society of America, Annual Meeting, South-central section, Norman, Oklahoma, March 29-30, 1982, p. 107.

Christenson, Scott, 1991, Geohydrology of the Central Oklahoma aquifer [abs.] in Christenson, Scott, and Carpenter, Lyn, eds., 1992, Ground-water quality of the Central Oklahoma (Garber-Wellington) aquifer conference: Proceedings, February 20, 1992: U.S. Geological Survey Open-File Report 92-116, p. 
Christenson, S.C., and Adams, G.P., 1987, Geohydrology of the freshwater/brine transition zone that surrounds the Ozark Plateaus, Oklahoma, Kansas, Missouri, and Arkansas [abs.] in Abstracts, Oklahoma Water Resources Conference, 1987, Stillwater, Oklahoma, September 29-30, 1987, p. 6, and in Geological Society of America Annual Meeting, South-central section, Lawrence, Kansas, March 14-15, 1988, p. 114, and in American Water Resources Assoc., 24th Annual Conference, Milwaukee, Wisconsin, November 6-8, 1988, p. 48.

Christenson, S.C., and Rea, A.H., 1991, Factors related to pesticide occurrence in ground water in the Oklahoma City urban area [abs.]: American Water Resources Association, 27th annual conference and symposium, New Orleans, 1991, Proceedings: Water management of river systems, p. 343-344.

Des

Christenson, Scott, and Rea, Alan, 1993, Ground-water quality in the Oklahoma City urban area: in Alley, W.M., ed., 1993, Regional ground-water quality: New York, Van Nostrand Reinhold, p. 589-611.

Clark, W.E., 1956, Forecasting the dryweather flow of Pond Creek, Oklahoma-A progress report: American Geophysical Union Transactions, v. 37 , no. 4 , p. 442 450.

Davis, R.E., and Christenson, S.C., 1979, Methods for digital-model evaluation of alluvial deposits of the North Canadian River, northwest Oklahoma [abs.]: Geological Society of America Annual Meeting, South-central Section, Mountain View, Arkansas, April 9-10, 1979, p. 146.

Dover, T.B., Horton, John, and Leonard, A.R., 1957, A look at the water resources of Oklahoma: Oklahoma City Geological Society Shale Shaker, v. 7, no. 10, p. 18-22, 24-32.
Fairchild, R.W., and Christenson, S.C., 1982, Potential contamination of the Roubidoux aquifer by water from abandoned zinc mines, northeastern Oklahoma [abs.]: Geological Society of America Abstracts with Programs, v. 13, no. 3.

Fairchild, R.W., and Davis, R.E., 1978, Structural control of ground-water flow in the Arbuckle Mountain area, south-central Oklahoma [abs.]: Geological Society of America Abstracts with Programs, v. 10, no. 1, p. 5 .

Fairchild, R.W., Davis, R.E., and Hanson, R.L., 1979, Aquifer characteristics of the Arbuckle aquifer, south-central Oklahoma [abs.]: Geological Society of America, South-Central Section, Mountain View, Ark., 1979, Proceedings, v. 11, no. 2, p. 147.

Frye, J.C., and Schoff, S.L., 1942, Deep-seated solution in the Meade basin and vicinity, Kansas and Oklahoma: American Geophysical Union Transactions, v. 24, pt. 1, p. 35-39.

Hamilton, P.A., Welch, A.H., Christenson, S.C., and Alley, W.M., 1993, Uses and limitations of existing ground-water quality data: in Alley, W.M., ed., 1993, Regional ground-water quality: New York, Van Nostrand Reinhold, p. 613-622.

Hanson, R.L., 1988, Use of base-flow data to manage water use during a drought, in Marvin Whetstone and R. John Burt, editors, Proceedings of the symposium on Wateruse data for water resources management, American Water Resources Association, 1988: Tucson, Arizona, p. 487-498.

Hart, D.L., Jr., and Davis, R.E., 1979, Geohydrology of the Antlers aquifer, southeastern Oklahoma [abs.]: Geological Society of America, South-Central Section, Mountain View, Ark., 1979, Proceedings, v. 11, no. 2, p. 148. 
Havens, J.S., 1982, Generalized altitude and configuration of the base of the High Plains aquifer, northwestern Oklahoma [abs.]: Geological Society of America Annual Meeting, South-Central Section, Norman, Oklahoma, March 29-30, 1982, p. 113.

Irwin, J.H., 1971, Ground-water investigations in Oklahoma, in Rose, W.D., ed., Environmental aspects of geology and engineering in Oklahoma: Annals of the Oklahoma Academy of Science Publication no. 2:, Oklahoma Geological Survey, p. 58.

1977, Water resources of Oklahoma, in Morris, J.W., ed., Geography of Oklahoma: Oklahoma City, Oklahoma Historical Society, p. 25-39.

Irwin, J.H., and Morton, R.B., 1970, Hydrogeologic information on the Ogallala Formation in the Oklahoma Panhandle and adjoining areas as related to underground waste disposal [abs.], Symposium on the Ogallala Aquifer: Lubbock, Texas, 1970, Texas Technological University, p. 30.

Johnson, K.S., Runkle, D.L., and Becker, M.F., 1990, Hydrogeology of the Rush SpringsMarlow aquifer in the Anadarko Basin, west-central Oklahoma, U.S.A.: Proceedings of the International Association of Hydrologists, Conference on Groundwater in Large Sedimentary Basins, Perth, Western Australia, July 9-10, 1990.

Leonard, A.R., 1960?, Ground water studies in Oklahoma: Midwestern States Flood Control and Water Resources Conference, 14th, Oklahoma City, 1959, 4 p. [Follows p. 52]

1961(?), Problems in protecting and developing underground waters in Oklahoma, in Industrial Wastes Conference, 11th, Oklahoma City, 1961(?), Proceedings, part 1: Oklahoma City, Oklahoma Water, Sewage, and Industrial Wastes Association, p. 51-55.
Moench, A.F., Sauer, V.B., and Jennings, M.E., 1974, Modification of routed streamflow by channel loss and base flow: Water Resources Research, v. 10, p. 963-968.

Mosier; E.L., Breit, G.N., Schlottmann, J.L., and Papp, C.S.E., 1990, Processes responsible for large concentrations of arsenic, chromium, selenium, uranium, and vanadium in water from the Central Oklahoma aquifer: Geological Society of America Annual Meeting, Program with abstracts, Dallas, Texas, October 29-November 1, 1990 , v. 22, no. 7, p. A61.

Muller, A.B., Parkhurst, D.L., and Tasker, P.W., 1986, Use of the PHREEQE code in modelling environmental geochemical problems encountered in performance assessment modelling, in U.S. Department of Energy, 1985, Symposium on groundwater flow and transport modelling for performance assessment of deep geologic disposal of radioactive waste-A critical evaluation of the state of the art: Albuquerque, N.Mex.

Playton, S.J., Davis, R.E., and McClaflin, R.G., 1978, Water quality in abandoned zinc mines in the Picher field, Tri-State mining district [abs.]: in Geological Society of America Abstracts with Programs, v. 10 , no. 1, p. 24.

Rea, A.H., and Christenson, Scott, 1992, Factors related to ground-water quality in the Oklahoma City urban area [abs.]: in Christenson, Scott, and Carpenter, Lyn, eds., 1992, Ground-water quality of the Central Oklahoma (Garber-Wellington) aquifer conference: Proceedings, February 20, 1992: U.S. Geological Survey Open-File Report 92-116, p. 21-22.

Rea, A.H., and Scott, J.C., 1990, A computer program to determine map coordinates from public land-survey coordinates [abs.]: in Balthrop, B.H, and Baker, E.G., 1990, U.S. Geological Survey national 
computer technology meeting: Program and abstracts, May 7-11, 1990: U.S. Geological Survey Open-File Report 90-161, p. 33.

Reed, E.W., and Schoff, S.L., 1952, Aquifers in Ottawa County, Oklahoma: Oklahoma Academy of Science Proceedings, v. 33, p. 194-195.

Runkle, D.L., and Johnson, K.S., 1988, Hydrologic study of a gypsum-dolomite karst aquifer in southwestern Oklahoma and adjacent parts of Texas, U.S.A.: Proceedings of the International Association of Hydrogeologists 21st Congress, Karst hydrogeology and karst environmental protection, October 10-15, 1988, Guilin City, Peoples Republic of China, v. 21, part 1 , p. $400-405$.

Sauer, V.B., 1973, Unit response method of open-channel flow routing: American Society of Civil Engineers Proceedings, Journal of the Hydraulics Division, v. 99, p. 179193.

Schlottmann, J.L. and Breit G.N., 1992, Mobilization of As and $U$ in the Central Oklahoma Aquifer: Proceedings of the 7th International Symposium on Water-Rock Interaction, Park City Utah, 13-19 July 1992, Rotterdam, A.A. Balkema.

Schoff, S.L., 1940, Ground Water in the Oklahoma Panhandle: Economic Geology, v. 35 , no. 4 , p. $534-545$.

1948, Ground-water supplies and uses in Oklahoma, in Oklahoma Conservation Conferences, 3d, 1948, Report of Proceedings: Stillwater, Okla., Oklahoma Research Foundation, Oklahoma Agricultural and Mechanical College, p. 24-36.

1955, Triassic rocks on Goff Creek, Texas County, Oklahoma: Oklahoma Academy of Science, v. XXXIV, p. 149152.
1956, Pliocene and Pleistocene fossils from Beaver County, Oklahoma: Oklahoma Academy Science Proceedings, v. 35, p. 94 .

Schoff, S.L., and Reed, E.W., 1951, Ground water in alluvial deposits in Oklahoma: Economic Geology, v. 46, no. 1, p. 76-83.

Smith, O.M., 1942, The chemical analysis of the waters of Oklahoma, with contributions by R.H. Dott and E.C. Warkentin: Oklahoma Agricultural and Mechanical College, Engineering Experiment Station Publication $52,474 \mathrm{p}$.

Tortorelli, R.L., 1991, Floodwater retarding structures effective in reducing peak discharge: American Society of Agricultural Engineers, International Winter Meeting, December 17-20, 1991, Chicago, Ill., Paper no. $912616,31 \mathrm{p}$.

\section{OTHER MISCELLANEOUS REPORTS}

Christenson, Scott, and Rea, A.H., 1992, Ground-water quality in the Oklahoma City urban area: in Alley, W.M., ed., Regional ground-water quality: Van Nostrand Reinhold, New York.

Gould, C.N., and Schoff, S.L., 1939, Geological report on water conditions at Platt National Park, Oklahoma: National Park Service Report 249, 38 p., 3 plates. [Also cataloged as U.S. Geological Survey OpenFile Report 39-14]

Irwin, J.H., 1971, The Glorieta Sandstone and the Ogallala Formation as related to underground disposal in the High Plains: Tulsa, Arkansas-White-Red River Basins Interagency Committee, January 1971, Minutes, appendix X, p. 2-15. 
Page

A

Adams, G.P. 31

Alf, L.A. .10

Alley, W.M. .31

Andreasen, G.E.

\section{B}

Barclay, J.E.

Becker, M.F.

Bedinger, M.S.

Bednar, G.A.

Bergman, D.L. 5, 8, 9, 14, 17, 18, 19, 21, 22, 23, 28, 29

$.10,18,26,28,29$

Bingham, R.H.

Blazs, R.L.

Blumer, S.P.

Bohn, J.D.

Boyle, D.L.

Branson, C.C.

Breit, G.N.

Briggs, P.H.

Bromery, R.W.

Buckner, H.D.

Bullock, J.H., Jr.

Burtis, V.M.

Burton, L.C. $.9,25,26$

\section{2} 9

23 $5,10,11,17,19,20,29,30$

$.10,16,29,30,32,33$

Doughten, Michael

Dover, T.B. $6,11,14,15,25,26,31$

E

Ellis, A.J.

Esposito, Ken .12

Fader, S.W. $.12,15$

F 10

\section{C}

Cady, R.C. .10

Carpenter, Lyn 10

Carr, J.E. 10,28

Cast, M.E. ...30

Christenson, S.C. $.8,11,16,18,19,20,30,31$

Christenson, Scott $10,12,16,31,32,33$

Clark, W.E. $.5,31$

Coffey, T.E. . .23

Cooter, E.J.

Corley, R.K. $11,17,21,22$

Crock J.G. ...15

Cummings, T.R. $.15,25$

\section{D}

D’Lugosz, J.J.

Davis, L.V.

Davis, R.E.

Dennis, P.E.

Dott, R.H.

$11,15,17,27,28,29$

$.11,12,13,16,27,31,32$ $17,28,29$

Frye, J.C

Funkhouser, R.A.

Fairchild, R.W.

Feder, G.L.

Ferree, D.M.

Fey, D.L. 12,23

Geurin, J.W.

Gilbert, C.R.

Goemaat, R.L.

Gould, C.N.

Gutentag, E.D.

$11,12,27,29,31$

\section{G} 11 25 $9,11,12,13,19$

Hall, A.E 13

Hamilton, P.A. ................................................. 31

Hanson, R.L. $6,12,13,27,31$

Hart, D.L., Jr. 8, 9, 11, 13, 14, 17, 19, 25, 27, 28, 29 , 31

Hauth, L.D. $10,13,23,29$

Havens, J.S.

Hearn, P.P.

Heimann, D.C.

Heimes, F.J. 6,19

Hoffman, G.L 19

Hollowell, J.R.

Horak, W.F.

Horton, John $6,10,11,13,19,27,28,29,32$

Huntzinger, T.L.

Irwin, J.H.

Jacobsen, C.L.

Jennings, M.E.

Johnson, K.S.

Johnson, W.D.

Kennedy, K.R.

Kennon, F.W. $9,11,14,17,20,22,23$ $24,32,33$ $14,26,28$ $28,32,33$ 15

$10,13,14,19$

$6,14,25$ 6,14 31

\section{I}

J 24

\section{$\mathbf{K}$} .6 
Kenny, J.F.

Kerestes, J.F.

Knott, R.K.

Krothe, N.C.

Kurklin, J.K.

$9,18,19$

$10,13,14,19,23$

\section{$\mathbf{L}$}

Laine, L.L.

Lalicker, D.G.

Leonard, A.R.

Lohman, S.W.

Luckey, R.R. $6,14,15,26$

$5,6,15,31,32$

.17

... 9

9,19

M

MacLachlan, M.E. .15

Madaj, A.J. 12

Marcher, M.V.

Marine, I.W.

McClaflin, R.G.

McKown, D.M.

McTernan, E.W.

Mesander, B.A.

Mills, W.B.

Miser, H.D.

Mize, L.D.

Moeller, M.D.

Moench, A.F.

Mogg, J.L.

Moore, R.L.

Morton, R.B.

Mosier, E.L.

Motooka, J.M.

Motts, W.S.

Muller, A.B

Murphy, J.J.

$6,15,25$

\section{$\mathbf{O}$}

Oakland, G.L

Oklahoma Water Resources Board

Oliver, J.W.

Orth, R.P.

Overton, M.D.

$8,9,11,12,15,20,24,27,29,32$

$10,15,24,29,32$ (2)

(5)

Peden, G.H.

Playton, S.J.

$16,27,32$

26

\section{$\mathbf{R}$}

Rea, A.H. $12,16,31,32,33$

Rea, Alan

16,31

Reed, E.W.

Reed, J.E.

Renick, B.C

5,20

Rice, Cyndi

Riddle, G.O.

Runkle, D.L. $14,26,27,28,29,33$ .6 10 15 32,33

\section{S}

Sapik, D.B.

Sauer, V.B. $20,32,33$

Schlottmann, J.L. $10,15,16,29,32,33$

Schoff, S.L. 11, 12, 15, 16, 17, 26, 27, 28, 30, 31, 33 Schuelein, J.W.

Schwenneson, A.T.

Scott, J.C. $10,13,16,20,30,32$

Slack, L.J. $17,19,20,29,30$

Smith, O.M. 33

Sneigocki, R.T.

Spiser, D.E.

Stacy, B.L. 12,15

Stanton, M.R. $15,17,26$

Steele, C.E. 30 .26 26 9,19 15,26 $\mathbf{P}$

Papp, C.S.E. $10,15,29,32$

Parkhurst, D.L.

Parkhurst, R.S. $11,16,32$

Pate, C.O. .20

Patneaude, A.L., Jr. .26

Patterson, J.L.
Stoner, J.D.

Sullivan, C.L.

Sullivan, C.W.

Swafford, B.F.

Tanaka, $H$

$\mathbf{T}$

Tasker, P.W. $6,17,27,30$

Theis, C.V. 32

Thomas, T.B. . .17

Thomas, W.O., Jr.

Thompson, D.C.

Tortorelli, R.L.

Turner, S.F. $6,14,17,19,20$ 18 .5 .5
Vaughn, R.B. 


\section{Page}

\section{W}

Waldrep, T.E.

.9

Walling, I.W.

Walters, D.M.

Walton, C.

Ward, P.E.

$5,18,30$

Warren, J.H.

.27

Weeks, J.B.

$9,13,21$

Weiss, D.L.

Welch, A.H.

Wells, C.V.

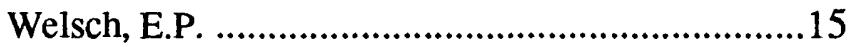

Westfall, A.O. ................................................... 18

White, D.K. ..............................................23

Wickersham, Ginia ..........................................26

Willard, C.C.

.12

Wood, P.R.

$.9,18,26,28$ 
Page

\section{$\mathbf{A}$}

Abandoned coal-mining area, hydrology, McCurtain, Haskell Co. .20

Aeromagnetic profiles, northeastern Oklahoma..........9 Alfalfa Co., geological report, Salt Plains reservoir ..17 Alfalfa Co., ground water, Cherokee area...................28 Alluvial deposits, ground water .33 Anadarko area, Caddo Co., ground water..................16 Anadarko Basin .15

Antlers aquifer, geohydrology. $.27,31$

Antlers aquifer, ground-water flow . .20 Antlers aquifer, southeastern Okla., hydrologic data.11 Antlers area, geohydrology . .13

Aquifer characteristics, Arbuckle aquifer ...................31

Aquifers, Ottawa County..........................................33

Arbuckle aquifer, characteristics..............................31

Arbuckle Mountain area, ground-water flow..............31

Arbuckle Mountain area, hydrologic data..................12

Arbuckle Mountain area, hydrology ...........................12

Arbuckle Mountain area, springs ..............................229

Arbuckle Mountains area, hydrology.........................27

Arbuckle Mountains, ground water.

Ardmore well-field area, Carter Co., ground-water levels, pumping. . .18

Ardmore-Sherman quadrangles, water resources.......28

Arkansas and Red River basins, salt spring, seeps, and plains.

Arkansas River basin, chemical quality, surface waters.

Arkansas River Basin, dissolved solids.

.6

Arkansas River near Fort Gibson, ground-water resources

Arkansas River, ground-water data, LeFlore, Haskell Co..

Arkansas River, ground-water data, Muskogee Co....17

Arkansas River, ground-water data, Sequoyah Co. ...17

Arkansas River, hydrology.

Arkansas River, Okla. and Tex., changes in chemical quality . .11

Arkansas River, polychlorinated biphenyls .17

Arkansas River, summary of annual records, chemical quality, 1945-52 18

Arkansas, White, and Red River basins .9

Arkansas, White, and Red River basins, ground water, depth to water
Arkansas, White, and Red River basins, principal ground-water investigations .. .9

Arkansas-White-Red Region, ground water ................5

Arsenic, chromium, selenium, uranium, and vanadium, Central Oklahoma aquifer 32

As, $\mathrm{Cr}, \mathrm{Se}, \mathrm{U}$, and $\mathrm{V}$, processes responsible for large concentrations, Central Oklahoma aquifer ..........29

Atlas, geology and earth resources of Oklahoma.......28

\section{B}

Base, fresh ground water, southern Okla. ...................8

Base-flow data, use during drought ...........................31

Basin characteristics, small streams .........................10

Beaver Co., fossils...................................................33

Beaver Co., geology and ground-water resources......30

Beaver Co., ground-water resources ..........................27

Beaver County, Okla., water resources.......................9

Beaver Creek basin, ground water in alluvium ..........13

Beaver Creek basin, surface water...........................15

Beaver-North Canadian River, Panhandle to Canton

Lake, geohydrology, numerical simulation .........11

Beaver-North Canadian River, Panhandle to Canton

Lake, hydrologic data ........................................11

Beckham Co., ground water in terrace deposits.........25

Beckham Co., Sandstone Creek ....................................6

Beggs area, Okmulgee Co., ground water..................16

Bibliography, Oklahoma hydrology, 1901-88...........13

Blanchard area, McClain Co., ground water............... 17

Blanchard area, McClain County, Okla., ground

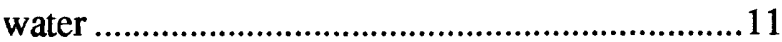

Blocker area, Pittsburg Co., hydrology ..................... 19

Blue Beaver Creek, flood Aug. 27-28, 1977 ............. 11

Blue Creek arm of Lake Eufaula and Blue Creek, water quality

C

Caddo Co., Anadarko area, ground water.................. 16

Caddo Co., Pond Creek basin, ground water .............28

Caddo Co., Rush Springs Sandstone, ground-water resources ...........................................................27

Caddo Co., Rush Springs sandstone, water-level and water-level change maps ...................................17

Canadian Co., ground-water resources .......................27

Canadian River valley near Norman, ground-water resources ...............................................................17

Carter Co., Ardmore well-field area, ground-water levels, pumping. 
Central Oklahoma (Garber-Wellington) aquifer conference, proceedings.

Central Oklahoma aquifer, arsenic, chromium, selenium, uranium, vanadium

Central Oklahoma aquifer, $\mathrm{As}, \mathrm{Cr}, \mathrm{Se}, \mathrm{U}$, and V, processes responsible for large concentrations.........29

Central Oklahoma aquifer, chemical analyses, geophysical logs

. .16

Central Oklahoma aquifer, general geology and solidphase geochemical studies...................................24

Central Oklahoma aquifer, geochemical evolution of ground waters.

.16

Central Oklahoma aquifer, geochemical studies, solidphase materials, relation to water quality ............15

Central Oklahoma aquifer, geohydrology...................30

Central Oklahoma aquifer, geohydrology and groundwater flow simulation

.10

Central Oklahoma aquifer, ground-water quality assessment 11,16

Central Oklahoma aquifer, ground-water-quality data, 1987-90.

. .12

Central Oklahoma aquifer, hydrogeologic maps....8, 11

Central Oklahoma aquifer, investigations, ground-water-quality assessment

.16

Central Oklahoma aquifer, mineralogy and petrography . .10

Central Oklahoma aquifer, mobilization of As and $U$

Central Oklahoma aquifer, Permian rock samples.....15

Central Oklahoma aquifer, Permian rocks, mineralogy and petrography

Central Oklahoma aquifer, rock/water interactions, ground-water contamination. .10

Central Oklahoma aquifer, see also Garber-Wellington aquifer

Central Oklahoma aquifer, sequential extraction analyses, drill core samples.

Central Oklahoma, elemental composition, surficial materials.

Channel changes, Sandstone Creek, nr Cheyenne, Okla,....

Characteristics of water, coal-mine ponds, 1977-81.17

Chemical analyses, Central Oklahoma aquifer ..........16

Chemical analyses, Picher mining area......................16

Chemical analyses, surface waters, Oklahoma, 1944

Chemical analyses, water, Mesozoic- and Paleozoicage formations
Chemical analysis, waters of Oklahoma. .33

Chemical and physical quality, Pryor Creek..............25

Chemical character surface water, North Boggy Creek basin. .14

Chemical character, public water supplies, 1953......25

Chemical character, surface waters, $1946-49 \ldots \ldots \ldots . . .26$

Chemical character, surface waters, $1949-50 \ldots \ldots . . . . .26$

Chemical character, surface waters, $1950-51$............25

Chemical character, surface waters, 1951-52 ............25

Chemical character, surface waters, $1952-53 \ldots \ldots \ldots . . .25$

Chemical character, surface waters, $1953-54 \ldots \ldots \ldots . . .25$

Chemical character, surface waters, 1954-55 ............25

Chemical character, surface waters, $1955-56$............25

Chemical character, surface waters, $1956-57$............26

Chemical character, surface waters, 1957-58 ............25

Chemical character, surface waters, $1958-59 \ldots \ldots \ldots \ldots . .25$

Chemical character, surface waters, $1959-60$............25

Chemical character, surface waters, 1960-61 ............25

Chemical character, surface waters, 1961-62 ............25

Chemical character, surface waters, 1962-63...........25

Chemical character, surface waters, Illinois River basin.................................................................. 14

Chemical character, surface waters, Washita River ba$\sin , 1946-47$. .26

Chemical quality changes, Arkansas River................11

Chemical quality of water, abandoned zinc mines.....27

Chemical quality of water, Creek, Lincoln, Okfuskee, Payne, Pottawatomie, Seminole Cos. ..................27

Chemical quality of water, zinc mines.......................16

Chemical quality, Arkansas River, summary, 1945-52. .18

Chemical quality, surface water, Little River basin... 14

Chemical quality, surface waters, Cottonwood Creek .15

Chickasaw National Recreation area, ground-water records

Chickasaw National Recreation Area, see Platt National Park

Chromium redistribution within continental red beds, pore-water chemistry ..........................................30

Cimarron Co., geology and ground-water resources .27 Cimarron County, Okla., ground-water resources .......9 Cimarron River basin, ground water..........................18 Cimarron River, ground water in terrace, Alfalfa, Garfield, Kingfisher, Major Cos..........................26

Cimarron terrace, salt-water detection .......................26 Cleveland, Oklahoma Cos., ground-water resources .28 Clinton quadrangle, water resources. 
Coal area, hydrologic data.

Coal-mine ponds, characteristics of water, 1977-81.17

Coal-mine ponds, physical and chemical characteristics of water.

29,30

Computer program, map coordinates from public landsurvey coordinates 16,32

Contamination by oil-well brines, Lake Wewoka, Seminole Co.

Contamination, ground-water, Central Oklahoma aquifer.

Continuous streamflow records, Okla.

Converting ground-water and water-quality data, NWIS to GIS.

Cottonwood Creek basin, ground water in alluvial deposits.

Cottonwood Creek, chemical quality, surface waters 15

Cottonwood Creek, surface waters. .15

Creek County, Okla., ground water. 10

Creek, Lincoln, Okfuskee, Payne, Pottawatomie, Seminole Cos., chemical quality of water .

Custer Co., ground water.

\section{D}

Davenport area, Lincoln Co., ground water .16

Deep well irrigation, Oklahoma Panhandle . .30

Digital model, Texas Co. .15

Digital-model evaluation, North Canadian River alluvium. . .31

Dissolved solids, Arkansas River Basin. .6

Double Creek sub-watershed no. 5, Washington County, Okla., fluvial sediment.

Drought, use of base-flow data .31

Droughts 6,13

Dry-weather flow, Pond Creek .31

Duke area, ground-water irrigation .29

\section{$\mathbf{E}$}

El Reno, Southwestern Reformatory, water supply ...17

Elk Creek basin, ground water ..................................25

Elk Creek basin, ground water in alluvium................ 14

Elk Creek basin, surface waters ................................. 18

Enid and vicinity, summary October 1973 rainstorm .30

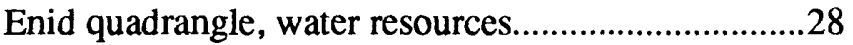

Enid, Flood of October 1973 .........................................18

Enid, ground-water condition.....................................16

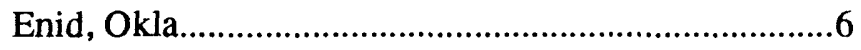

Enid, Okla., ground water .......................................... 6
Estimating flood depths, Oklahoma streams.............21

Estimating flood discharges, Oklahoma streams .......21

Estimating historical irrigation requirements, High

Plains .................................................................19

Evapotranspiration and droughts.................................6

Evapotranspiration, Pond Ck. basin, Okla. ..................5

F

Factor related to ground-water quality, Oklahoma City urban area .........................................................16

Flood characteristics, Oklahoma streams...................20

Flood frequency, estimating for urban areas..............20

Flood insurance study, Choctaw ...............................22

Flood insurance study, City of the Village.................21

Flood insurance study, Duncan .................................22

Flood insurance study, Edmond ...............................21

Flood insurance study, Enid.....................................22

Flood insurance study, Jones.......................................22

Flood insurance study, McAlester............................22

Flood insurance study, Midwest City........................22

Flood insurance study, Mustang ...............................22

Flood insurance study, Nichols Hills .........................21

Flood insurance study, Nicoma Park .......................22

Flood insurance study, North Enid............................22

Flood insurance study, Oklahoma City .....................22

Flood insurance study, Oklahoma County .................23

Flood insurance study, Piedmont ..............................22

Flood insurance study, Ponca City..............................22

Flood insurance study, Sallisaw .................................21

Flood insurance study, Spencer.................................22

Flood insurance study, Valley Brook..........................22

Flood insurance study, Warr Acres..........................22

Flood of May 26-27, 1984, Tulsa, Okla......................8

Flood of October 1973, Enid......................................18

Flood of September 1940, Cleveland .........................26

Flood peak discharges, Oklahoma .............................21

Flood, August 27-28, 1977, West Cache Creek, Blue Beaver Creek .......................................................11

Floodflows, small drainage areas, progress report.....17

Floods and droughts ................................................6

Floods in Oklahoma ................................................18

Floods of April-June 1957, Okla. and western Ark. .. 18

Floods on Glover Creek and Little River, 1971-72 ...21

Floods, central, southwest Okla., Oct. 17-23, 1983 ..13

Floods, May 1951, western Okla. and northwestern Tex.

Floods, south-central Oklahoma, north-central

Texas .10 
Floodwater retarding structures..................................33

Flow routing, open-channel, unit response method ...33

Flowerpot Shale, halite deposits....................................5

Fluvial sediment, Washington Co., Okla. ....................9

Fort Sill, water supply .............................................. 12

Fort Smith quadrangle, water resources.....................29

Fossils, Beaver Co.....................................................33

Freshwater/brine transition zone, Ozark Plateaus, geohydrology.

\section{G}

Gage, Ellis County, Okla., ground water .6

Gaines Creek and Gaines Creek arm of Eufaula Lake, water quality .19

Garber-Wellington aquifer, preliminary appraisal .....10

Garber-Wellington aquifer, records of wells and water quality .10

Garber-Wellington ground water basin, ground-water resources, Cleveland, Oklahoma, Pottawatomie Cos.

General geology and solid-phase geochemical studies, Central Oklahoma aquifer. .24

Geochemical evolution of ground water, Central Oklahoma aquifer. .16

Geochemical studies, solid-phase materials, Central Oklahoma aquifer, relation to water quality ........15

Geohydrology and ground-water flow simulation, Central Oklahoma aquifer

Geohydrology, Antlers aquifer............................27, 31

Geohydrology, Antlers area . .13

Geohydrology, Beaver-North Canadian River............11

Geohydrology, Central Oklahoma aquifer..................30

Geohydrology, North Canadian River from Oklahoma City to Eufaula Lake. . .19

Geohydrology, Oklahoma Panhandle, Beaver, Cimarron, and Texas Cos. .19

Geohydrology, Ozark Plateaus.

.31

Geohydrology, Roubidoux aquifer. .11

Geohydrology, Vamoosa aquifer . 11

Geohydrology, Vamoosa-Ada aquifer ......................227

Geologic logs, deep wells, Okla., Tex., N.Mex. ........11

Geologic map, Oklahoma..........................................24

Geological report, Salt Plains reservoir site, Alfalfa Co. .17

Geology and earth resources of Oklahoma, atlas.......28

Geology and ground-water resources, Beaver Co......30 Geology and ground-water resources, Cimarron Co..27 Geology and ground-water resources, Ottawa Co.....27
Geology and ground-water resources, Texas Co. ......27 Geology and ground-water resources, Woodward

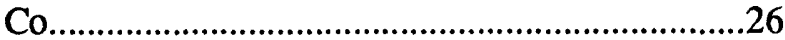

Geology and water resources of Oklahoma .................6 Geology and water resources, Grady, Stephens Cos..27 Geology of Oklahoma ground-water supplies ...........28 Geology, ground-water hydrology, Lake Hefner.......11 Geophysical logs, Central Oklahoma aquifer ............16 Geophysical logs, Picher field.....................................11

Glover Creek and Little River, 1971-72 floods.........21 Grady, Stephens Cos., geology and water resources .27 Grand (Neosho) River basin, ground water ...............15 Great Salt Plains, effects of chloride-control structures. .20

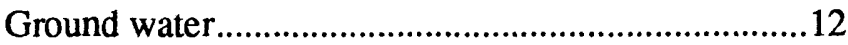

Ground water at high stage, Oklahoma Panhandle ....30 Ground water in alluvial deposits, Cottonwood Creek basin .17

Ground water in alluvium, Beaver Creek basin .........13

Ground water in alluvium, Elk Creek basin...............14

Ground water in alluvium, Washita River, Clinton to Anadarko ..........................................................25

Ground water in terrace deposits, Beckham Co........25

Ground water studies, Oklahoma ..............................32

Ground water, alluvial deposits, Oklahoma................33

Ground water, Arbuckle Mountains..........................29

Ground water, Arkansas, White, Red River basins......9

Ground water, Beggs area, Okmulgee Co.................16

Ground water, Blanchard area, McClain Co.............17

Ground water, Caddo Co., Anadarko area ..................16

Ground water, Cherokee area, Alfalfa Co...................28

Ground water, Cimarron River basin..........................18

Ground water, Cimarron River, Alfalfa, Garfield, King-

fisher, Major Cos. ...............................................26

Ground water, Creek County, Okla..........................10

Ground water, Custer Co..........................................27

Ground water, Davenport area ..................................16

Ground water, Elk Creek basin .................................25

Ground water, Gage, Okla. ........................................6

Ground water, Grand (Neosho) River basin ..............15

Ground water, Kingfisher Co..................................28

Ground water, middle Arkansas River basin ............12 Ground water, Mississippian rocks, Miami, Okla......14

Ground water, Okla.................................................15

Ground water, Oklahoma Panhandle ........................33

Ground water, Otter Creek basin ..............................25

Ground water, pesticides, Oklahoma City urban area 
Ground water, Pond Creek basin, Caddo Co.

Ground water, Roosevelt, Okla.

Ground water, Texas County, Okla.

Ground water, Verdigris River basin, Kans., and Okla.

Ground water, Washita River.

15

Ground water, Wichita Mountains

13,27

Ground-water circulation, salt springs .........................5

Ground-water conditions, Enid ................................16

Ground-water flow, Antlers aquifer ..........................20

Ground-water flow, Arbuckle Mountain area............31

Ground-water investigations, Oklahoma..............11, 32

Ground-water irrigation, Duke area ..........................29

Ground-water irrigation, Duke area, Jackson, Greer

Cos. . .28

Ground-water levels, 1956-60, Okla.

Ground-water levels, 1965-66, Okla.

Ground-water levels, 1969-70, Okla

Ground-water levels, 1971-74, Okla.

Ground-water levels, 1979-80, Okla

Ground-water levels, 1980-82, Okla

Ground-water levels, 1982-83, Okla

Ground-water levels, 1983-84, Okla.

Ground-water levels, changes during 1957.

Ground-water levels, Okla.

Ground-water levels, Oklahoma, 1961-62

Ground-water levels, Oklahoma, 1963-64

Ground-water levels, period of record-March 1985 , Okla.

Ground-water levels, pumping, Ardmore well-field area, Carter Co.

Ground-water levels, 1975, Okla.

. .12

Ground-water pumpage and water levels,

Oklahoma......

Ground-water quality assessment, Central Oklahoma aquifer. . .16

Ground-water quality data, 1981, Okla.

.12

Ground-water quality data, 1982-84, Okla.

.12

Ground-water quality, existing, uses and limitations.31

Ground-water quality, Okla... .6

Ground-water quality, Oklahoma...............................14

Ground-water quality, Oklahoma City urban area ....31, 32,33

Ground-water records, Chickasaw National Recreation Area, Murray Co.

Ground-water records, eastern Okla., water-quality records.

Ground-water records, northeastern Oklahoma ......... 14
Ground-water records, southeastem Oklahoma.........14

Ground-water reservoirs, Oklahoma, map..................28

Ground-water resources, Arkansas River nr Fort Gibson.

Ground-water resources, Beaver Co. .........................27

Ground-water resources, Canadian Co. ....................27

Ground-water resources, Canadian River valley near Norman ...........................................................17

Ground-water resources, Cimarron County, Okla. ......9

Ground-water resources, Cleveland, Oklahoma Cos. 28

Ground-water resources, Garber-Wellington groundwater basin.

26

Ground-water resources, Harmon, Jackson, Greer

Cos.

Ground-water resources, Okla. ................................6

Ground-water resources, Rush Springs Sandstone, Caddo Co.

27

Ground-water resources, terrace deposits and alluvium, Tillman Co.......................................................25

Ground-water storage increases, Tillman Co.............30

Ground-water studies, lower Arkansas and Verdigris

River valleys

Ground-water studies, Oklahoma.............................13

Ground-water supplies and development, Oklahoma 29

Ground-water supplies and uses, Oklahoma..............33

Ground-water supplies, Oklahoma City area ............28

Ground-water-level data, Water-Supply Papers...........7

Ground-water-quality assessment data, Central Oklahoma aquifer 1987-90...........................................12

Ground-water-quality assessment, Central Oklahoma aquifer, investigations.......................................16

Ground-water-quality sampling network, random siteselection approaches ..........................................20

\section{H}

Halite deposits, Woodward, Woods Cos....................30

Haskell Co., McCurtain, abandoned coal-mining

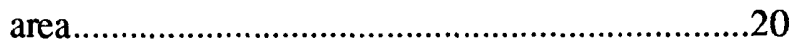

Haskell Co., Stigler area, hydrology .........................20

High Plains and their utilization, The .......................24

High Plains aquifer, base..........................................32

High Plains aquifer, bedrock geology, altitude of base,

1980 saturated thickness ........................................9

High Plains aquifer, dissolved solids, sodium .............9

High Plains aquifer, sulfur isotopic composition.......19

High Plains aquifer, water table, 1978 ......................13

High Plains aquifer, water-level and saturated-thickness changes , 列

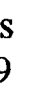

\section{0}

\section{4}

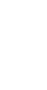

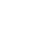




\section{Page}

High Plains regional aquifer systems analysis, plan of study . .21

High Plains regional aquifer, 1980 saturated

thickness

High Plains regional aquifer, 1980 water table. .19

High Plains regional aquifer, base

High Plains regional aquifer, numerical simulation...19

High Plains regional aquifer, predevelopment water table.

High Plains regional aquifer, water-level changes.....19

High Plains, estimating historical irrigation requirements. .19

High Plains, underground disposal. 33

High-flow frequencies, selected streams, Okla..........14

Historically black colleges and universities, cooperative activities with USGS. . .13

Hydrogeologic information, Glorieta Sandstone and Ogallala Formation, Oklahoma Panhandle..........24

Hydrogeologic maps, Central Oklahoma aquifer.......11

Hydrogeology, Oklahoma Panhandle ..........................9

Hydrogeology, Rush Springs-Marlow aquifer...........32

Hydrologic and physical data, Sandstone Creek, 1951-56 .25

Hydrologic data, Antlers aquifer 11

Hydrologic data, Arbuckle Mountain area.................12

Hydrologic data, Beaver-North Canadian River........11

Hydrologic data, coal area, southeastern Okla...........10

Hydrologic data, Lehigh area...................................10

Hydrologic data, North Canadian River, Lake Over-

holser-Eufaula Lake ...........................................13

Hydrologic data, Vamoosa aquifer.............................11

Hydrologic Unit Map, Oklahoma...............................24

Hydrologic-data collection, overview .........................29

Hydrology of Area 40 ............................................20

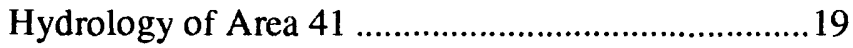

Hydrology, Arbuckle Mountain area .........................12

Hydrology, Arbuckle Mountains area .......................27

Hydrology, Arkansas River..........................................6

Hydrology, Blocker area, Pittsburg Co......................19

Hydrology, Red Oak area, Latimer Co. .....................20

Hydrology, Rock Island area, Le Flore Co. ...............20

Hydrology, Stigler area, Haskell Co. .......................20

\section{I}

Illinois River basin, chemical character. 14

Illinois River basin, surface waters 14

Index, published surface-water-quality data, Okla., 1946-75

\section{$\mathbf{J}$}

Jackson; Greer Cos., ground-water irrigation, Duke area..........................................................28

\section{$\mathbf{K}$}

Karst, gypsum-dolomite, hydrologic study ...............33

Kiamichi River basin, quality of water ...................... 15

Kiamichi River basin, surface water ......................... 15

Kingfisher Co., ground water.................................28

\section{L}

Lake Hefner area, Oklahoma County, geology and ground-water hydrology ....................................11

Lake Hefner, geology and ground-water hydrology ..11

Lake Hefner, water-loss investigations ........................5

Lake Wewoka, contamination by oil-well brines, Seminole Co.

Land-use and land-cover data, ground-water sampling

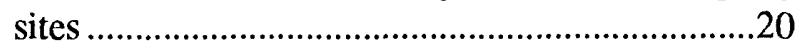

Latimer Co., Red Oak area, hydrology ....................20

Laverne formation...................................................30

Lawton quadrangle, water resources.........................28

Le Flore Co., Rock Island area, hydrology ...............20

LeFlore, Haskell Co., ground-water data, Arkansas River ..............................................................17

Lehigh area, hydrologic data................................... 10

Limited detail flood insurance study, Bryan Co., and incorporated area ................................................22

Limited detail flood insurance study, Pocola .............22

Limited detail flood insurance study, Tishomingo ....22

Lincoln Co., Davenport area, ground water...............16

Little River basin, chemical quality, surface waters ..14

Little River basin, surface water ..............................18

Little River basin, surface waters..............................14

Lower Arkansas and Verdigris River valleys, groundwater studies . .5

Low-flow characteristics, Oklahoma streams ............ 14

\section{M}

Major sources of water in Oklahoma. .28

McAlester-Texarkana quadrangles, water resources .29

McClain Co., Blanchard area, ground water..............17

McClain County, ground water................................11

McCurtain Co., oil possibilities .................................28

McCurtain, Haskell Co., abandoned coal-mining area..................................................................20

Meade basin, deep-seated solution..............................31

Miami, Okla, ground water, Mississippian rocks ......14 
Miami, Okla, pumping tests ......................................14

Mid-Arkansas and Upper Red River basins, sediment data through 1980

.10

Middle Arkansas River basin, Kans. and Okla., ground water...

Mineral constituents in water

Mineralogy and petrography, Central Oklahoma aquifer.

Minicomputers, use in water-resources investigations . 30

Mississippian rocks, ground water, Miami, Okla.......14

Mobilization of As and U, Central Oklahoma aquifer. 33

Muddy Boggy River basin, surface waters ................18

Murray Co., ground-water records

Muskogee Co., ground-water data, Arkansas River...17

\section{$\mathbf{N}$}

$\mathrm{Na} / \mathrm{Cl}$ ratios, western Okla. .5

National water-Quality Assessment program, land-use and land-cover data... .20

Noble Co., water resources .26

North Boggy Creek basin, chemical character, surface waters . .14

North Boggy Creek basin. surface waters . .14

North Canadian River alluvium, digital-model evaluation...

North Canadian River, Canton Lake to Lake Overholser, numerical simulation. 30

North Canadian River, Canton Lake to Lake Overholser, numerical simulation, alluvium and terrace aquifer . .18

North Canadian River, Lake Overholser-Lake Eufaula, hydrologic data . .13

North Canadian River, Oklahoma City to Eufaula Lake, geohydrology. .19

North Fork of Canadian River, ground water ..............6 Northeastern Oklahoma, aeromagnetic profiles...........9 Northeastern Oklahoma, ground-water records .........14 Northeastern Oklahoma, springs.............................29 Northeastern Oklahoma, springs, Ozark Region........29 Numerical simulation, alluvium and terrace aquifer, North Canadian River from Canton Lake to Lake Overholser. . .18

Numerical simulation, Beaver-North Canadian

River .11

Numerical simulation, High Plains regional aquifer..19
Numerical simulation, North Canadian River, Canton Lake to Lake Overholser ...30

\section{$\mathbf{O}$}

Ogallala aquifer, Texas Co., digital model .................15

Ogallala aquifer, water-level changes .......................29

Ogallala aquifer, water-quality sampling...................18

Ogallala aquifer, see High Plains aquifer

Ogallala Formation, hydrogeologic information.........32

Ogallala Formation, underground waste disposal......32

Oil possibilities, Idabel, McCurtain Co......................28

Oklahoma and western Arkansas, floods of April-June 1957 .18

Oklahoma City area, ground-water supplies..............28

Oklahoma City quadrangle, water resources .............28

Oklahoma City urban area, factors related to groundwater quality .16

Oklahoma City urban area, ground-water quality.....31, 32,33

Oklahoma City urban area, pesticide occurrence.......31

Oklahoma City, urban flood analysis.........................17

Oklahoma County ...................................................11

Oklahoma hydrology, bibliography, 1901-88 ...........13

Oklahoma Panhandle, Beaver, Cimarron, and Texas Cos., geohydrology ..........................................19

Oklahoma Panhandle, climatic cycles.........................6

Oklahoma Panhandle, deep well irrigation .................30

Oklahoma Panhandle, ground water ..........................33

Oklahoma Panhandle, ground water at high stage .....30

Oklahoma Panhandle, hydrogeologic information, Glorieta Sandstone and Ogallala Formation..............24

Oklahoma Panhandle, hydrogeology .........................9

Oklahoma Panhandle, records of water wells and test holes.................................................................14

Oklahoma Panhandle, water-level measurements, 1966-70

Oklahoma Panhandle, water-level measurements,

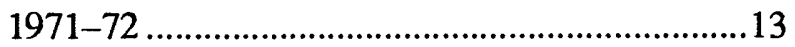

Oklahoma streams, estimating flood depths .............21

Oklahoma streams, estimating flood discharges........21

Oklahoma streams, flood characteristics....................20

Oklahoma streams, low-flow characteristics .............14

Oklahoma, surface-water resources .............................5

Oklahoma surface waters, water type and suitability, Part 1

Oklahoma surface waters, water type and suitability, Part 2 
Oklahoma surface waters, water type and suitability, Part 3. .21

Oklahoma surface waters, water type and suitability, Part 4.

Oklahoma surface waters, water type and suitability, Part 5. .21

Oklahoma water. .26

Oklahoma water issues. . .7

Oklahoma water-Quantity, occurrence, and quality of surface and ground water..................................26

Oklahoma, alluvial deposits 33

Oklahoma, chemical analysis of waters. 33

Oklahoma, continuous streamflow records.

Oklahoma, flood peak discharge. ...10

Oklahoma, floods 21

Oklahoma, geologic map. . .18

Oklahoma, geology of ground-water supplies

Oklahoma, ground water.

Oklahoma, ground-water investigations

Oklahoma, ground-water levels

Oklahoma, ground-water levels, 1956-60

Oklahoma, ground-water levels, 1961-62

Oklahoma, ground-water levels, 1963-64

Oklahoma, ground-water levels, 1965-66

Oklahoma, ground-water levels, 1969-70

Oklahoma, ground-water levels, 1971-74

Oklahoma, ground-water levels, 1975

Oklahoma, ground-water levels, 1979-80

Oklahoma, ground-water levels, 1980-82

Oklahoma, ground-water levels, 1982-83

Oklahoma, ground-water levels, 1983-84

Oklahoma, ground-water levels, period of recordMarch 1985

Oklahoma, ground-water pumpage and water levels. 30

Oklahoma, ground-water quality... . .14

Oklahoma, ground-water quality data, 1981 ..............12

Oklahoma, ground-water quality data, 1982-84.......12

Oklahoma, ground-water studies.. 13,32

Oklahoma, ground-water supplies and development.29

Oklahoma, ground-water supplies and uses. .33

Oklahoma, high-flow frequencies, selected streams.. 14

Oklahoma, hydrologic unit map. .24

Oklahoma, index, surface-water-quality data, 1946-75 .17

Oklahoma, major sources of water. .28

Oklahoma, map ground-water reservoirs ...................28

Oklahoma, problems, underground water...................32

Oklahoma, public water supplies
Oklahoma, salt springs . 30

Oklahoma, statistical summaries, streamflow records, through 1984 19

Oklahoma, summary of activities, 1983 ...................13

Oklahoma, summary of activities, 1985 .................... 18

Oklahoma, summary of activities, 1986-87 ............. 13

Oklahoma, summary of activities, 1988-90 ..............14

Oklahoma, surface-water-quality data, statistical sum-

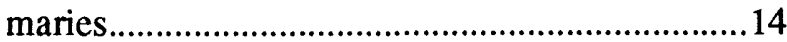

Oklahoma, water facts...........................................17

Oklahoma, water resources .................................31, 32

Oklahoma, water-level records, 1975-77 .................12

Oklahoma, water-level records, 1976-78 ..................12

Oklahoma, water-resources investigations................24

Oklahoma's underground water................................29

Oklahoma-Ground-water quality.............................6

Oklahoma-Ground-water resources..........................6

Oklahoma - Water supply and use...............................6

Okmulgee Co., Beggs area, ground water...................16

Okmulgee Co., water resources ...............................27

Ottawa Co., geology and ground-water resources .....27

Ottawa County, aquifer ..............................................33

Otter Creek basin, ground water ..............................25

Otter Creek basin, surface waters...............................18

Ozark Plateaus, geohydrology ..................................31

Ozark Region, northeastern Oklahoma, springs ........29

\section{$\mathbf{P}$}

Permian rock samples, Central Oklahoma aquifer.....15 Permian rocks, Central Oklahoma aquifer.................10 Permian rocks, Central Oklahoma aquifer, rock/water interaction, ground-water contamination............. 10

Pesticide occurrence, ground water, Oklahoma City ur-

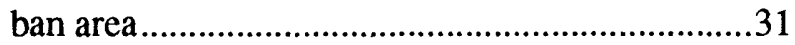

PHREEQE code, use in modeling.............................32

Physical and chemical characteristics of water, coalmine ponds 29

Picher field, geophysical logs ..................................11

Picher mining area, chemical analyses, water samples 16

Picher mining area, stream sediment ........................16

Pittsburg Co., Blocker area, hydrology .....................19

Platt National Park, geological report on water conditions

Platt National Park, water conditions.........................33

Polecat Creek basin, surface-water resources ............14

Polychlorinated biphenyls, Arkansas River ...............17

Pond Creek basin, Caddo Co., ground water ..............28 
Pond Creek basin, evapotranspiration...........................5

Pond Creek, dry-weather flow ....................................31

Potential contamination, Roubidoux aquifer, zinc mines.

. .31

Problems, underground waters in Oklahoma .............32

Progress report, floodflows, small drainage areas......17

Pryor Creek, chemical and physical quality...............25

Public water supples, chemical character, 1953.........25

Public water supplies, Okla..................................... 15

Pumping tests, Miami, Okla.................................... 14

\section{$\mathbf{Q}$}

Quality of water, Kiamichi River basin 15

Quality of water, zinc mines. .16

Quality-of-water records of Oklahoma, 1964

. .23

\section{$\mathbf{R}$}

Rainfall-runoff hydrographs, small streams. .10

Records of selected water wells and test holes, Oklahoma Panhandle .14

Red Oak area, Latimer Co., hydrology .....................20

Reservoirs, Sandstone Creek watershed, Beckham and Roger Mills Co.

20

Rock Island area, Le Flore Co., hydrology ................20

Roger Mills Co., Sandstone Creek ..............................6

Roosevelt, Okla., ground water................................. 14

Roubidoux aquifer, geohydrology, water quality.......11

Roubidoux aquifer, potential contamination..............31

Rush Springs Sandstone, Caddo Co., ground-water resources.

27

Rush Springs sandstone, water-level and water-level change maps, Caddo Co.

Rush Springs wells, unusual fluctuations...................29

Rush Springs-Marlow aquifer, hydrogeology .............32

\section{$\mathbf{S}$}

Salt Plains reservoir site, Alfalfa Co., geological report.

Salt springs, ground-water circulation

Salt springs, Oklahoma .30

Salt springs, seeps, and plains, Arkansas and Red River basins .18

Salt-water detection, Cimarron terrace.........................26

Sandstone Creek

...6

Sandstone Creek watershed, hydrologic and physical data, 1951-56. .25

Sandstone Creek, channel changes. 5

Sediment data through 1980, Mid-Arkansas and Upper Red River basins
Self-supplied domestic water use, Oklahoma, 1980..21 Seminole Co., contamination by oil-well brines, Lake Wewoka.. .17

Sequential extraction analyses, drill core samples, Central Oklahoma aquifer .........................................15

Sequoyah Co., ground-water data, Arkansas River ... 17 Shallow halite deposits, Flowerpot Shale, southwestern Oklahoma.

Small streams in Okla., rainfall-runoff hydrographs, basin characteristics .10

Solution, deep-seated, Meade basin .31

Southeastern Okla., hydrologic data, coal area .......... 10

Southeastern Oklahoma, ground-water records .........14

Southem Okla., base fresh ground water .....................8

Southwestern Reformatory, El Reno, water supply...17

Springs, Arbuckle Mountain area .............................29

Springs, northeastern Oklahoma .............................29

Springs, Ozark Region, northeastern Oklahoma........29

Statistical processor for analyzing simulations, modular model .20

Statistical summaries, streamflow records, Oklahoma, through 1984 .19

Statistical summaries, streamflow records, through

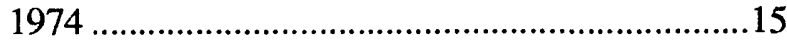

Statistical summaries, surface-water-quality data......14

Stigler area, Haskell Co., hydrology ...........................20

Stream sediment, Picher mining area........................16

Streamflow data program, proposed ......................... 10

Streamflow records, statistical summaries, through 1974 .15

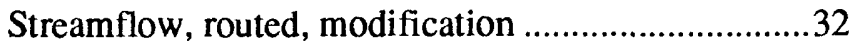

Sulfur isotopic composition, High Plains aquifer ......19

Summary appraisals, ground-water, Arkansas-WhiteRed Region .5

Summary of activities, USGS WRD, 1983 ...............13

Summary of activities, USGS WRD, $1985 \ldots \ldots \ldots \ldots \ldots . . .18$

Summary of activities, USGS WRD, 1986-87.........13

Summary of activities, USGS WRD, 1988-90..........14

Summary of October 1973 rainstorm, Enid and vicinity ............................................................30

Surface water, Beaver Creek basin ...........................15

Surface water, chemical quality, Arkansas River basin .................................................................. 11

Surface water, Kiamichi River basin ........................15

Surface water, Little River basin.........................14, 18

Surface water, Washita River basin, chemical character,

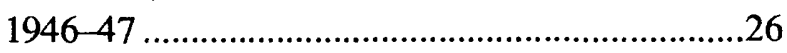

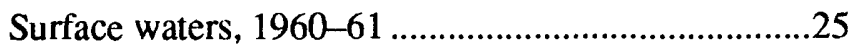


Surface waters, chemical analyses, 1944 ...................17

Surface waters, chemical character, $1946-49$...........26

Surface waters, chemical character, 1949-50 ............26

Surface waters, chemical character, 1950-51 ...........25

Surface waters, chemical character, 1951-52 ...........25

Surface waters, chemical character, 1952-53 ...........25

Surface waters, chemical character, 1953-54 ...........25

Surface waters, chemical character, 1954-55 ............25

Surface waters, chemical character, 1955-56 ............25

Surface waters, chemical character, 1956-57 ...........26

Surface waters, chemical character, 1957-58 ...........25

Surface waters, chemical character, 1958-59 ...........25

Surface waters, chemical character, 1959-60 ...........25

Surface waters, chemical character, 1961-62 ...........25

Surface waters, chemical character, 1962-63 ...........25

Surface waters, Cottonwood Creck ............................15

Surface waters, Elk Creek basin.................................18

Surface waters, Illinois River basin.............................14

Surface waters, Muddy Boggy River basin................18

Surface waters, North Boggy Creck basin ................. 14

Surface waters, Otter Creek basin ...............................18

Surface-water data, Water-Supply Papers....................8

Surface-water records of Oklahoma. 1961-64...........23

Surface-water resources, Okla.....................................5

Surface-water resources, Polecat Creek basin............14

Surface-water resources, Washita River basin........... 14

Surface-water-quality data, Oklahoma, index, 1946-75

Surface-water-quality data, statistical summaries, through 1975, Oklahoma ....................................14

Surface-water-quality data, Water-Supply Papers .......7

Surficial materials, central Oklahoma, clemental composition

\section{$\mathbf{T}$}

Tar Creek basin, Picher mining area, stream

sediment. .16

Texas Co., geology and ground-water resources .......27

Texas Co., Ogallala aquifer, digital model.................15

Texas Co., Triassic rocks, Goff Creck .......................33

Texas County, Okla., ground water...............................9

Tillman Co., ground-water resources, terrace deposits and alluvium

Tillman Co., ground-water storage increases.............30

Triassic rocks, Goff Creck, Texas Co.........................33

Tulsa Co., water resources .....................................27

Tulsa quadrangle, water resources ..........................29

Tulsa, Okla., flood, May 26-27, 1984.

\section{$\mathbf{U}$}

Underground disposal, High Plains.............................33

Underground water, Oklahoma ................................29

Underground waters in Oklahoma, problems ............32

Unusual fluctuations in Rush Springs wells...............29

Urban flood analysis, Oklahoma City .......................17

Urban storm water management, application of hydrau-

lic and hydrologic data

Uses and limitations, existing ground-water quality..31

\section{V}

Vamoosa aquifer, geohydrology 11

Vamoosa aquifer, hydrologic data

Vamoosa-Ada aquifer, geohydrology

Verdigris River basin, Kans. and Okla., ground water...

Verdigris River valley, geohydrology .........................6

Verdigris River, correlative estimates, discharge ......15 Verdigris River, ground-water data, Wagoner, Rogers

Co.

\section{W}

Wagoner, Rogers Co., ground-water data, Verdigris River

Washita River basin, surface-water resources............14

Washita River, ground water in alluvial deposits ...... 15

Washita River, ground water in alluvium, Clinton to

Anadarko

.25

Waste disposal, Ogallala Formation ............................32

Water conditions, Platt National Park................. 12, 33

Water facts for Oklahoma ........................................ 17

Water for Oklahoma...................................................6

Water quality, abandoned zinc mines ........................32

Water quality, Blue Creek arm of Lake Eufaula and

Blue Creck

Water quality, Gaines Creek and Gaines Creek arm of

Eufaula Lake.

Water quality, Roubidoux aquifer.

Water resources data for Oklahoma-Part 1, Surfacewater records, 1965-74. .23

Water resources data for oklahoma-Part 2, Waterquality records, 1965-74 .23

Water resources data, Oklahoma, 1975.....................24

Water resources data, Oklahoma, 1976.....................24

Water resources data, Oklahoma, 1977.....................24

Water resources data, Oklahoma, 1978......................24

Water resources data, Oklahoma, 1979.....................24

Water resources data, Oklahoma, 1980......................24 
Water resources data, Oklahoma, 1981

Water resources data, Oklahoma, 1982

Water resources data, Oklahoma, 1983

Water resources data, Oklahoma, 1984

Water resources data, Oklahoma, 1985

Water resources data, Oklahoma, 1986

Water resources data, Oklahoma, 1987

Water resources data, Oklahoma, 1988

Water resources data, Oklahoma, 1989

Water resources data, Oklahoma, 1990

Water resources data, Oklahoma, 1991

Water resources data, Oklahoma, 1992, vol. 1, Arkansas

River Basin

.23

Water resources data, Oklahoma, 1992, vol. 2, Red River Basin

.23

Water resources, Ardmore-Sherman quadrangles......28

Water resources, Beaver County, Okla.......................9

Water resources, Clinton quadrangle .......................28

Water resources, Enid quadrangle..............................28

Water resources, Fort Smith quadrangle....................29

Water resources, Lawton quadrangle .28

Water resources, McAlester-Texarkana quadrangles.29

Water resources, Noble Co.

Water resources, Oklahoma 31,32

Water resources, Oklahoma City quadrangle.............28

Water resources, Okmulgee Co. .27

Water resources, Tulsa Co. .27

Water resources, Tulsa quadrangle .29

Water resources, Woodward quadrangle .29

Water supply and use, Okla. .6

Water supply, Fort Sill . .12

Water supply, Southwestern Reformatory, El Reno..17

Water, mineral constituents. .11

Water, physical and chemical characteristics, coal-mine ponds. .30

Water-level changes, Ogallala aquifer. .29

Water-level fluctuations in wells.
Water-level fluctuations, climatic cycles, Oklahoma Panhandle.

Water-level measurements, 1966-70, Oklahoma Panhandle.

Water-level measurements, 1971-72, Oklahoma Panhandle.

Water-level records, 1950-75, western Okla............. 12

Water-level records, 1975-76, western Okla.............12

Water-level records, 1975-77, Okla........................12

Water-level records, 1976-78, Okla.........................12

Water-loss investigations, Lake Hefner ......................

Water-quality records, eastern Okla.........................13

Water-quality sampling, Ogallala aquifer .................18

Water-resources investigations, Oklahoma...............24

Water-Supply Papers, ground-water-level data ...........7

Water-Supply Papers, surface-water-quality data........ 7

Water-Supply Papers, surface-water data .................... 8

Wells, water quality, Garber-Wellington aquifer....... 10

West Cache Creek, flood, Aug. 27-28, 1977............11

Western Oklahoma, water-level records, 1950-75 ....12

Western Oklahoma, water-level records, 1975-76 ....12

Wichita Mountains, ground water.......................13, 27

Withdrawals and use of water, Oklahoma, 1982 ......21

Woodward Co., geology and ground-water resources ..........................................................26

Woodward quadrangle, water resources ....................29

Woodward, Woods Cos., halite deposits .....................30

\section{$\mathbf{Z}$}

Zinc mines, abandoned, chemical quality of water....27

Zinc mines, abandoned, water quality.........................32

Zinc mines, chemical quality of water ........................16

Zinc mines, potential contamination, Roubidoux aquifer. 31

Zinc mines, quality of water.....................................16 


\section{REPORTS BY U.S. GEOLOGICAL SURVEY, SORTED BY REPORT NUMBER}

\section{Annual Reports}

AR 21

AR 22

Circ 0630

Circ 1019

FEMA 400027

FEMA 400062

FEMA 400077

FEMA 400080

FEMA 400141

FEMA 400170

FEMA 400199

FEMA 400202

FEMA 400252

FEMA 400357

FEMA 400405

FEMA 400409

FEMA 400412

FEMA 400420

FEMA 400423

FEMA 400424

FEMA 400425

FEMA 400432

FEMA 400445

FEMA 400449

FEMA 400466

FEMA 400482

FEMA 405378
Johnson, W.D., 1901, The High Plains and their utilization 24

Johnson, W.D., 1902, The High Plains and their utilization 24

\section{Circulars}

Irwin, J.H., and Morton, R.B., 1969, Hydrogeologic information on the Glorieta Sandstone and Ogallala Formation in the Oklahoma Panhandle and adjoining areas as related to underground waste disposal 24 Mosier, E.L., and Bullock, J.H., Jr., 1988, Review of the general geology and solidphase geochemical studies in the vicinity of the Central Oklahoma aquifer 24

\section{Federal Emergency Management Flood Insurance Studies}

Tortorelli, R.L., 1982, Town of Piedmont, Oklahoma ................................ 22

Huntzinger, T.L., 1979a, City of Enid, Oklahoma 22

Tortorelli, R.L., 1988, Limited detail flood insurance study, City of Tishomingo, Johnston County, Oklahoma ................................................................22

Corley, R.K., 1980, City of Ponca City, Oklahoma ...................................... 22

Huntzinger, T.L., and Tortorelli, R.L., 1981a, Town of Jones, Oklahoma .......... 22

Huntzinger, T.L., 1979b, City of McAlester, Oklahoma ................................ 22

Bergman, D.L., 1980a, City of Sallisaw, Oklahoma .................................. 21

Bergman, D.L., and Walton, C., 1979, City of Duncan, Oklahoma .................. 22

Bergman, D.L., 1980b, City of Edmond, Oklahoma ..................................... 21

Huntzinger, T.L., 1981b, City of Choctaw, Oklahoma ................................ 22

Huntzinger, T.L., 1981c, City of Midwest City, Oklahoma ............................ 22

Huntzinger, T.L., 1980a, City of Mustang, Oklahoma ................................. 22

Huntzinger, T.L., and Tortorelli, R.L., 1980a, City of Spencer, Oklahoma ........ 22

Bergman, D.L., 1980c, City of the Village, Oklahoma ................................. 21

Bergman, D.L., 1982, City of Nichols Hills, Oklahoma ............................... 21

Huntzinger, T.L., 1980b, Town of Nicoma Park, Oklahoma .......................... 22

Huntzinger, T.L., 1981a, Town of North Enid, Oklahoma ........................... 22

Tortorelli, R.L., 1989, Limited detail flood insurance study, Town of Pocola, Le Flore

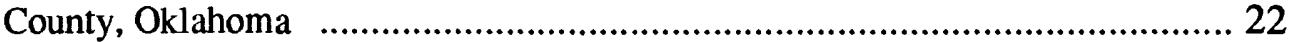

Huntzinger, T.L., and Tortorelli, R.L., 1981b, Town of Valley Brook, Oklahoma 22

Huntzinger, T.L., and Tortorelli, R.L., 1980b, City of Warr Acres, Oklahoma ... 22

Tortorelli, R.L., Huntzinger, T.L., and Bergman, D.L., 1982, Oklahoma County,

Oklahoma

Tortorelli, R.L., 1990, Limited detail flood insurance study, Bryan County, and incorporated areas 22 Huntzinger, T.L., Tortorelli, R.L., and Bergman, D.L., 1982, City of Oklahoma City, Oklahoma 


\section{Hydrologic Investigations Atlases}

HA 0002

HA 0003

HA 0223

HA 0250

HA 0373

HA 0450

HA 0648

HA 0652

HA 0658

HA 0707

HA 0724

I 738

Misc

Misc

Misc

OFR 18-001

OFR 31-001

OFR 34-002

OFR 37-002

Lohman, S.W., Burtis, V.M., and others, 1953a, Areas of principal ground-water investigations in the Arkansas, White, and Red River basins

Lohman, S.W., Burtis, V.M., and others, 1953b, General availability of ground water and depth to water level in the Arkansas, White, and Red River basins .............. 9 Hart, D.L., Jr., 1966, Base of fresh ground water in southern Oklahoma ............. 8 Wood, P.R., and Hart, D.L., Jr., 1967, Availability of ground water in Texas County, Oklahoma

\section{9}

Sapik, D.B., and Goemaat, R.L., 1972, Reconnaissance of the ground-water resources

of Cimarron County, Oklahoma

Morton, R.B., and Goemaat, R.L., 1972, Reconnaissance of the water resources of Beaver County, Oklahoma

Weeks, J.B., and Gutentag, E.D., 1981, Bedrock geology, altitude of base, and 1980 saturated thickness of the High Plains aquifer in parts of Colorado, Kansas, Nebraska, New Mexico, Oklahoma, South Dakota, Texas, and Wyoming

Luckey, R.R., Gutentag, E.D., and Weeks, J.B., 1981, Water-level and saturatedthickness changes, predevelopment to 1980, in the High Plains aquifer in parts of Colorado, Kansas, Nebraska, New Mexico, Oklahoma, South Dakota, Texas, and Wyoming 9 Krothe, N.C., Oliver, J.W., and Weeks, J.B., 1982, Dissolved solids and sodium in water from the High Plains aquifer in parts of Colorado, Kansas, Nebraska, New Mexico, Oklahoma, South Dakota, Texas, and Wyoming ............................... 9 Bergman, D.L., and Tortorelli, R.L., 1988, Flood of May 26-27, 1984 in Tulsa, Oklahoma

Christenson, S.C., Morton, R.B., and Mesander, B.A., 1992, Hydrogeologic maps of the Central Oklahoma aquifer, Oklahoma 8

\section{Miscellaneous Geologic Investigations}

Morton, R.B., 1973, Preliminary investigations of the hydrogeology of the Middle Permian to Tertiary rocks of the Oklahoma Panhandle

\section{Miscellaneous Reports}

Miser, H.D., 1954, Geologic map of Oklahoma ........................................... 24

U.S. Geological Survey, 1976, Hydrologic Unit Map of Oklahoma-1974 ........ 24

U.S. Geological Survey, 1977, Water-resources investigations in Oklahoma, 1976

\section{Open-File Reports}

Ellis, A.J., 1918, Sources of water supply for the military establishments at Fort Sill, Oklahoma Turner, S.F., 1931, Report on water supply for the proposed Southwestern Reformatory at El Reno, Oklahoma

Theis, C.V., 1934, Preliminary geological report on the Salt Plains reservoir site (Alfalfa County), Oklahoma 
OFR 39-014

OFR 41-032

OFR 45-110

OFR 45-111

OFR 48-000

OFR 48-080

OFR 48-081

OFR 48-082

OFR 48-083

OFR 48-084

OFR 50-068

OFR 50-069

OFR 51-120

OFR 51-121

OFR $51-200$

OFR 51-201

OFR 53-288

OFR 53-289

OFR 55-036

OFR 56-075

OFR 57-040

OFR 57-127

OFR 58-058

OFR 58-059

OFR 58-063

OFR 59-075
Gould, C.N., and Schoff, S.L., 1939, Geological report on water conditions at Platt National Park, Oklahoma

Schoff, S.L., Dott, R.H., and Lalicker, D.G., 1941, Contamination of Lake Wewoka and fresh-water sands by disposal of oil-well brines near Wewoka, Seminole County, Oklahoma 17

U.S. Geological Survey, 1945a, Water facts for Oklahoma ........................... 17 U.S. Geological Survey, 1945b, Chemical analyses of surface waters in Oklahoma, September-December 1944 17 Schoff, S.L., and Davis, L.V., 1948, Ground water in the Blanchard area, McClain County, Oklahoma 17

Davis, L.V., and Schoff, S.L., 1948, Ground water in the Blanchard area, McClain County, Oklahoma 11 Schoff, S.L., 1948a, Ground-water conditions in the vicinity of Enid, Oklahoma 16 Schoff, S.L., 1948b, Ground-water in the Beggs area, Okmulgee County, Oklahoma 16 Schoff, S.L., 1948c, Ground-water available in the Davenport area (Lincoln County), Oklahoma 16

Schoff, S.L., 1948d, Ground water in the Anadarko area (Caddo County),

Oklahoma

Dennis, P.E., 1950, Geology and ground-water hydrology of the Lake Hefner area in Oklahoma County, Oklahoma ............................................................... 11 Dover, T.B., 1950, Mineral constituents in water and their significance ............ 11 Jacobsen, C.L., 1951, Memorandum on ground water from Mississippian rocks in the vicinity of Miami, Okla.

Jacobsen, C.L., and Reed, E.W., 1951, Memorandum on results of pumping tests at Goodrich plant site, Miami, Okla 14

Barclay, J.E., 1951, Ground-water levels in Oklahoma ................................... 9 Laine, L.L., Schoff, S.L., and Dover, T.B., 1951, Public water supplies in Oklahoma 15 U.S. Geological Survey, 1953(?), Summary of annual records of chemical quality of the Arkansas River in Oklahoma and Arkansas, 1945-1952 18 Dover, T.B., and Geurin, J.W., 1953(?), Changes in chemical quality of the Arkansas River in Oklahoma and Texas (1946-52) ................................................ 11 Davis, L.V., 1955, Ground-water investigations in Oklahoma ....................... 11 Laine, L.L., 1956, Surface-water resources of Polecat Creek basin, Oklahoma ... 14 Dover, T.B., 1957, Chemical quality of surface waters in the Arkansas River basin of Oklahoma 11 Weiss, D.L., and Sullivan, C.L., 1958(?), Floods of April-June 1957 in Oklahoma and western Arkansas 18 Laine, L.L., 1958a, Surface-water resources of the Washita River basin in Oklahoma-magnitude, distribution, and quality of streamflow 14 Laine, L.L., 1958b, Surface waters of North Boggy Creek basin in the Muddy Boggy Creek basin in Oklahoma, with a section on Chemical character of surface water, by T.B. Dover 14 Leonard, A.R., Davis, L.V., and Stacy, B.L., 1958, Ground water in the alluvial deposits of the Washita River and its tributaries in Oklahoma 15 Laine, L.L., 1959a, Surface waters of Little River basin in central Oklahoma, with a section on Chemical character of surface waters, by T.B. Dover 14 
OFR 59-076

OFR 59-077

OFR $60-130$

OFR 60-138

OFR 60-166

OFR 61-059

OFR 61-065

OFR 61-067

OFR 61-177

OFR 62-075

OFR 62-155

OFR 62-162

OFR 63-000

OFR 63-003

OFR 63-132

OFR 63-138

OFR 63-148

OFR 63-150

OFR 63-151

OFR 64-112

OFR $64-169$

OFR 64-170

OFR 65-155

Laine, L.L., 1959b, Surface waters of lllinois River basin in Arkansas and Oklahoma, with a section on Chemical character of surface waters, by T.B. Dover ............. 14 Laine, L.L., 1959c, Correlative estimates of discharge for Verdigris River (tributary to Arkansas River) near Tenapah, Oklahoma, for year ending September 30, 1938

Stacy, B.L., 1960, Ground water in the alluvial deposits of Cottonwood Creek basin,

Oklahoma 17

Tanaka, H.H., 1960, Water-level and water- level change maps for the irrigation area in the Rush Springs sandstone in Caddo County and adjacent area .................. 17

Leonard, A.R., 1960, Ground water in Oklahoma ................................... 15

Hart, D.L., Jr., 1961, Ground water in the alluvium of Beaver Creek basin, Oklahoma

Hollowell, J.R., 1961a, Ground water in the alluvium of Elk Creek basin, Oklahoma (OWRB Bulletin 28) 14

Hollowell, J.R., 1961b, Ground water in the vicinity of Roosevelt, Oklahoma ... 14 Stacy, B.L., 1961, Ground-water resources of the alluvial deposits of the Canadian River valley near Norman, Oklahoma

Laine, L.L., 1962, Surface waters of Cottonwood Creek in the Cimarron River basin in central Oklahoma, with a section on Chemical quality of surface waters, by R.P. Orth 15 Westfall, A.L., 1962b, Surface waters of Otter Creck basin in southwestern Oklahoma, with a section on Chemical quality of surface water, by J.J. Murphy ...... 18 Laine, L.L., and Murphy, J.J., 1962, Surface water of Beaver Creek basin in southcentral Oklahoma

Laine, L.L., 1963, Surface water of Kiamichi River basin in southeastern Oklahoma, with a section on Quality of water, by T.R. Cummings 15 Andreasen, G.E., and Bromery, R.W., 1963, Total intensity aeromagnetic profiles over northeastern Oklahoma

Ward, P.E., 1961, Geology and ground-water features of salt springs, seeps, and plains in the Arkansas and Red River basins of western Oklahoma and adjacent parts of Kansas and Texas 18 Westfall, A.O., 1962a, Surface waters of Elk Creck basin in southwestern Okla-

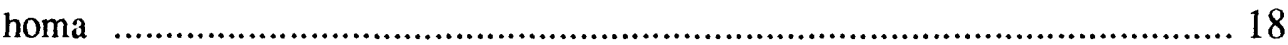
Westfall, A.O., 1963a, Surface water of Muddy Boggy River basin in south-central Oklahoma, with a section on Quality of water, by T.R. Cummings ................. 18 Hart, D.L., Jr., 1963, Ground-water levels in observation wells in Oklahoma, 1956-60

Westfall, A.O., 1963b, Surface water of Little River basin in southeastern Oklahoma, with a section on Quality of water, by R.P. Orth 18 MacLachlan, M.E., 1964, The Anadarko Basin (of parts of Oklahoma, Texas, Kansas, and Colorado) 15 Wood, P.R., and Moeller, M.D., 1964, Ground-water levels in observation wells in Oklahoma, 1961-62 18 Westfall, A.O., and Patterson, J.L., 1964, Floods in Oklahoma, magnitude and frequency 18 Tanaka, H.H., Hart, D.L., Jr., and Knott, R.K., 1965a, Ground-water data of selected test holes and wells along the Arkansas River in Muskogee County, Oklahoma . 17 
OFR 65-156

OFR 65-157

OFR 65-158

OFR 65-176

OFR 65-184

OFR 66-159

OFR 67-285

OFR 69-335

OFR 70-032

OFR 71-344

OFR 72-463

OFR 72-464

OFR 73-022

OFR 73-376

OFR 74-1099

OFR 75-365

OFR 75-366

OFR 75-367

OFR 75-684

OFR 76-619

OFR 76-664

OFR 76-889
Tanaka, H.H., Hart, D.L., Jr., and Knott, R.K., 1965b, Ground-water data of selected test holes and wells along the Verdigris River in Wagoner and Rogers Counties Oklahoma

Tanaka, H.H., Hart, D.L., Jr., and Knott, R.K., 1965c, Ground-water data of selected test holes and wells along the Arkansas River in Sequoyah County, Oklahoma . 17 Tanaka, H.H., Hart, D.L., Jr., and Knott, R.K., 1965d, Ground-water data of selected test holes and wells along the Arkansas River in LeFlore and Haskell Counties, Oklahoma

Wood, P.R., 1965a, Records of ground-water levels and effects of pumping in the Ardmore well-field area, Carter County, Oklahoma 18

Wood, P.R., 1965b, Ground-water levels in observation wells in Oklahoma, 1963-64

U.S. Geological Survey, 1966, Ground water in the Cimarron River basin, New Mexico, Colorado, Kansas, and Oklahoma 18

Hart, D.L., Jr., 1967, Ground-water levels in observation wells in Oklahoma, 1965-66

Bingham, R.H., 1969, Ground-water levels in observation wells in Oklahoma, 1967-68

Bohn, J.D., and Hoffman, G.L., 1970, A proposed streamflow data program for Oklahoma

Hart, D.L., Jr., and others, 1971, Records of water-level measurements in wells in the Oklahoma Panhandle, 1966-70

Moore, R.L., 1972, Ground-water levels in observation wells in Oklahoma, 1969-70

Hart, D.L., Jr., Hoffman, G.L., and Goemaat, R.L., 1972, Records of water-level measurements in the Oklahoma Panhandle, 1971-72 13 Bednar, G.A., and Waldrep, T.E., 1973, Fluvial sediment in Double Creek sub-watershed no. 5, Washington County, Oklahoma

Hoffman, G.L., and Hart, D.L., Jr., 1973, Records of selected water wells and test holes in the Oklahoma Panhandle 14 Thomas, W.O., Jr., and Corley, R.K., 1974, Floodflows from small drainage areas in Oklahoma-Progress report and data compilation 17

Fader, S.W., and Morton, R.B., 1975, Ground water in the Verdigris River basin, Kansas and Oklahoma 12 Morton, R.B., and Fader, S.W., 1975, Ground water in the Grand (Neosho) River basin, Kansas and Oklahoma

Fader, S.W., and Morton, R.B., 1975, Ground water in the middle Arkansas River basin, Kansas and Oklahoma

Mize, L.D., 1975, Statistical summaries of streamflow records, Oklahoma, through 1974 15

Carr, J.E., and Havens, J.S., 1976, Records of wells and water quality for the GarberWellington aquifer, northern Oklahoma and southern Logan Counties,

Oklahoma 10

Goemaat, R.L., 1976, Ground-water levels in observation wells in Oklahoma, 1971-74 12

Havens, J.S., and Bergman, D.L., 1976a, Ground-water records for southeastem Oklahoma-Part 1, Records of wells, test holes, and springs 14 
OFR 76-890

OFR 77-074

OFR 77-163

OFR 77-204

OFR 77-238

OFR 77-239

OFR 77-278

OFR 77-487

OFR 78-000

OFR 78-161

OFR 78-166

OFR 78-294

OFR 78-357

OFR 78-414

OFR 78-721

OFR 78-781

OFR 78-857

OFR 78-1038

OFR 79-219

OFR 79-256

OFR 79-565

OFR $79-1580$

OFR $80-050$
Havens, J.S., and Bergman, D.L., 1976b, Ground-water records for northeastern Oklahoma—Part 1, Records of wells, test holes, and springs 14 Goemaat, R.L., 1977a, Selected water-level records for western Oklahoma, 1950-75 12

Playton, S.J., and Davis, R.E., 1977, Preliminary report on the quality of water in abandoned zinc mines in northeastern Oklahoma and southeastern Kansas ....... 16 Stoner, J.D., 1977, Index of published surface- water-quality data for Oklahoma, 1946-1975

Goemaat, R.L., 1977b, Ground-water levels in observation wells in Oklahoma, 1975 12

Goemaat, R.L., 1977c, Selected water-level records for western Oklahoma, 1975-76

Carr, J.E., and Marcher, M.V., 1977, A preliminary appraisal of the Garber-Wellington aquifer, southern Logan and northern Oklahoma Counties, Oklahoma ........ 10 D'Lugosz, J.J., and McClaflin, R.G., 1977, Hydrologic data for the Vamoosa aquifer, east-central Oklahoma ............................................................................ 11 Hart, D.L., Jr., and Davis, R.E., 1978, Geohydrology of the Antlers area, southeastern Oklahoma (OGS Circular 81) 13

Huntzinger, T.L., 1978a, High-flow frequencies for selected streams in

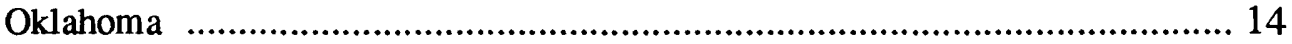

Huntzinger, T.L., 1978b, Low-flow characteristics of Oklahoma streams ......... 14 Playton, S.J., Davis, R.E., and McClaflin, R.G., 1980, Chemical quality of water in abandoned zinc mines in northeastern Oklahoma and southeastern Kansas (OGS Circular 82) 16

Havens, J.S., 1978a, Ground-water records for eastern Oklahoma-Part 2, Waterquality records for wells, test-holes, and springs ........................................ 13 Huntzinger, T.L., 1978c, Application of hydraulic and hydrologic data in urban storm water management 14 Goemaat, R.L., and Spiser, D.E., 1978, Selected water-level records for Oklahoma, 1975-77 12 D'Lugosz, J.J., and McClaflin, R.G., 1978, Geohydrology of the Vamoosa aquifer, east-central Oklahoma …........................................................................... 11 Havens, J.S., 1978b, Reconnaissance of ground water in the vicinity of the Wichita Mountains, southwestern Oklahoma (OGS Circular 85)

Davis, R.E., and Hart, D.L., Jr., 1978, Hydrologic data for the Antlers aquifer, southeastern Oklahoma 11 Kurklin, J.K., 1979, Statistical summaries of surface-water-quality data for selected sites in Oklahoma, through the 1975 water year 14 Corley, R.K., and Huntzinger, T.L., 1979, Flood of August 27-28, 1977, West Cache Creek and Blue Beaver Creek, southwestern Oklahoma 11 Morton, R.B., 1980, Digital-model projection of saturated thickness and recoverable water in the Ogallala aquifer, Texas County, Oklahoma 15 Goemaat, R.L., and Spiser, D.E., 1979, Selected water-level records for Oklahoma, 1976-78

Gutentag, E.D., and Weeks, J.B., 1980, Water table in the High Plains aquifer in 1978 in parts of Colorado, Kansas, Nebraska, New Mexico, Oklahoma, South Dakota, and Wyoming 13 
OFR $80-159$

OFR $80-216$

OFR 80-975

OFR $81-483$

OFR 81-824

OFR $82-775$

OFR $83-026$

OFR 83-027

OFR $83-028$

OFR 83-686

OFR 83-692

OFR 83-760

OFR 83-767

OFR 84-065

OFR $84-447$

OFR $84-472$

OFR 84-599

OFR 84-724

OFR 84-747

OFR 84-808

OFR 85-087

OFR $85-328$

OFR $85-417$

OFR 85-494
Davis, R.E., Christenson, S.C., and Blumer, S.P., 1980, Hydrologic data for the alluvium and terrace aquifer along the Beaver-North Canadian River from the Panhandle to Canton Lake, northwestern Oklahoma 11

Stoner, J.D., 1980, Reconnaissance of polychlorinated biphenyls in the Arkansas River between Muskogee and Webbers Falls Lock and Dam, Oklahoma .......... 17 Mills, W.B., and Spiser, D.E., 1980, Selected water-level records for Oklahoma, 1979-80

Davis, R.E., and Christenson, S.C., 1981, Geohydrology and numerical simulation of the alluvium and terrace aquifer along the Beaver-North Canadian River from the Panhandle to Canton Lake, northwestern Oklahoma .................................. 11 Bergman, D.L., and Huntzinger, T.L., 1981, Rainfall-runoff hydrographs and basin characteristics data for small streams in Oklahoma ....................................... 9 Fairchild, R.W., Hanson, R.L., and Davis, R.E., 1982, Hydrology of the Arbuckle Mountain area

Tortorelli, R.L., Huntzinger, T.L., Bergman, D.L., and Patneaude, A.L., Jr., 1983, Urban flood analysis in Oklahoma City, Oklahoma 17 Goemaat, R.L., and Willard, C.C., 1983, Ground-water records for the area surrounding the Chickasaw National Recreation Area, Murray County, Oklahoma ........ 12 Fairchild, R.W., 1983, Hydrologic data for Arbuckle Mountain area, south-central Oklahoma 12

Ferrec, D.M., 1983, Ground-water quality data for Oklahoma, 1981 12 Blumer, S.P., 1983, Sediment data for Mid-Arkansas and Upper Red River basins through 1980

Goemaat, R.L., Mize, D.L., and Spiser, D.E., 1983, Ground-water levels in observation wells in Oklahoma, 1980-82

Hanson, R.L., Scott, J.C., and Kurklin, J.K., 1983, Oklahoma-A summary of activities of the U.S. Geological Survey, Water Resources Division for 1983

Buckner, H.D., and Kurklin, J.K., 1984, Floods in south-central Oklahoma and northcentral Texas

Slack, L.J., and Blumer, S.P., 1984, Physical and chemical characteristics of water in coal-mine ponds, eastem Oklahoma, June to November 1977-81 (OGS Sp. Pub. 87-2) 17

Goemaat, R.L., Mize, D.L., and Spiser, D.E., 1984, Ground-water levels in observation wells in Oklahoma, 1982-83 climatic years

Blumer, S.P., and Scott, J.C., 1984, Hydrologic data for the Lehigh area, southeastern

Oklahoma, May 1977 to January 1982 10

Hanson, R.L., 1984, Droughts 13 Blumer, S.P., and Hauth, L.D., 1984, Use and availability of continuous streamflow records in Oklahoma

Havens, J.S., 1985, Hydrologic data, North Canadian River from Lake Overholser to Lake Eufaula, central Oklahoma 13 Goemaat, R.L., Mize, D.S., and Spiser, D.E., 1985, Ground-water levels in observation wells in Oklahoma, 1983-84 climatic years U.S. Geological Survey, 1985, Oklahoma- A summary of activities of the U.S. Geological Survey, Water Resources Division, for 1985 ..................................... 18 Ferree, D.M., 1985, Ground-water quality data for Oklahoma-1982-84 ......... 12 Hauth, L.D., 1985, Floods in central, southwest Oklahoma, October 17-23, 198313 
OFR 86-314

OFR 86-319

OFR 86-541

OFR 87-235

OFR $87-453$

OFR 87-746

OFR $88-140$

OFR 88-172

OFR 88-469

OFR $88-728$

OFR 89-033

OFR 90-161

OFR 90-161

OFR 90-288

OFR 90-456

OFR $90-570$

OFR 90-579

OFR 90-678

OFR 91-093

OFR 91-213

OFR 91-347

OFR $91-442$

Goemaat, R.L., Mize, L.D., Madaj, A.J., and Spiser, D.E., 1986, Ground-water levels in observation wells in Oklahoma, period of record to March 1985 12 Blumer, S.P., and Alf, L.A., 1986, Hydrologic data for selected streams in the coal area of southeastern Oklahoma, July 1978 to September 1982 10 Christenson, S.C., Morton, R.B., Havens, J.S., and Fairchild, R.W., 1988, Geologic logs for selected deep wells in parts of Oklahoma, Texas, and New Mexico ...... 11 Christenson, S.C., and Parkhurst, D.L., 1987, Ground-water quality assessment of the Central Oklahoma aquifer, Oklahoma 11 Parkhurst, D.L., 1987, Chemical analyses of water samples from the Picher mining area, northeast Oklahoma and southeast Kansas 16 Horak, W.F., and Stoner, J.D., 1988, Oklahoma ground-water quality ............. 14 Havens, J.S., 1988b, U.S. Geological Survey ground-water studies in Oklahoma 13 Havens, J.S., 1988a, Oklahoma, a summary of activities of the U.S. Geological Survey, Water Resources Division, in fiscal years 1986-87 13

Parkhurst, D.L., Doughten, Michael, and Hearn, P.P., 1988, Chemical analyses of stream sediment in the Tar Creek basin of the Picher mining area, northeast Oklahoma 16 Parkhurst, D.L., Christenson, S.C., and Schlottmann, J.L., 1989, Ground-water quality assessment of the Central Oklahoma aquifer, Oklahoma-Analysis of available water-quality data through 1987 16 Havens, J.S., 1989, Bibliography of Oklahoma hydrology-Reports prepared by the U.S. Geological Survey and principal cooperating agencies, 1901-88 .............. 13 Balthrop, B.H, and Baker, E.G., 1990, U.S. Geological Survey national computer technology meeting - Program and abstracts, May 7-11, 1990 ..................... 16 Rea, A.H., and Scott, J.C., 1990, A computer program to determine map coordinates from public land-survey coordinates 16 Breit, G.N., Mosier, E.L., Schlottmann, J.L., and Papp, C.S.E., 1990, Rock/water interactions and ground-water contamination in Permian rocks, Central Oklahoma aquifer 10

Mosier, E.L., Briggs, P.H., Crock, J.G., Kennedy, K.R., McKown, D.M., Vaughn, R.B., and Welsch, E.P., 1990, Analyses of subsurface Permian rock samples from the Central Oklahoma aquifer 15 Christenson, S.C., Parkhurst, D.L., and Fairchild, R.W., 1990, Geohydrology and water quality of the Roubidoux aquifer, northeastern Oklahoma ..................... 11 Christenson, S.C., Morton, R.B., and Mesander, B.A., 1990, Hydrogeologic maps of the Central Oklahoma aquifer, Oklahoma (HA 724) 11 Breit, G.N., Rice, Cyndi, Esposito, Ken, and Schlottmann, J.L., 1990, Mineralogy and petrography of Permian rocks in the Central Oklahoma aquifer ..................... 10 Hall, A.E., and Scott, J.C., 1991, Cooperative activities of the U.S. Geological Survey with historically black colleges and universities, fiscal year 1983-90 13 Christenson, S.C., Thomas, T.B., Overton, M.D., Goemaat, R.L., and Havens, J.S., 1991, Geophysical logs for selected wells in the Picher field, northeast Oklahoma and southeast Kansas 11 Mosier, E.L., Papp, C.S.E., Motooka, J.M., Kennedy, K.R., and Riddle, G.O., 1991, Sequential extraction analyses of drill core samples, Central Oklahoma aquifer . 15 Mosier, E.L., Bullock, J.H., Jr., Fey, D.L., Kennedy, K.R., McKown, D.M., Vaughn, R.B., and Welsch, E.P., 1991, Elemental composition of surficial materials from central Oklahoma 15 
OFR 91-464

OFR 91-492

OFR 92-116

OFR 92-116

OFR 92-116

OFR 92-116

OFR 92-116

OFR 92-116

OFR 92-641

OFR 92-642

PP 0269

PP 0424-D

PP 0450-B

PP 0450-E

PP 0450-E

PP 0475-C

PP 0813-H

WDR OK-75-1

WDR OK-76-1
Schlottmann, J.L., and Funkhouser, R.A., 1991, Chemical analyses of water samples and geophysical logs from cored test holes drilled in the Central Oklahoma aquifer 16 Havens, J.S., 1991, Oklahoma, a summary of activities of the U.S. Geological Survey, Water Resources Division, in fiscal years 1988-90 14 Breit, G.N., 1992, Mineralogy and petrography of Permian rocks in the Central Oklahoma aquifer: Implications for ground-water quality 10 Christenson, Scott, 1992, Geohydrology and ground-water flow simulation of the Central Oklahoma aquifer

Christenson, Scott, and Carpenter, Lyn, eds., 1992, Ground-water quality of the Central Oklahoma (Garber-Wellington) aquifer conference, Proceedings, February 20, 1992 10

Mosier, E.L., and Schlottmann, J.L., 1992, Geochemical studies of solid-phase materials in the Central Oklahoma aquifer-relation to water quality 15 Parkhurst, D.L., 1992, The geochemical evolution of ground waters in the Central Oklahoma aquifer 16 Rea, Alan, and Christenson, Scott, 1992, Factors related to ground-water quality in the Oklahoma City urban area 16 Ferree, D.M., Christenson, Scott, Rea, A.H., and Mesander, B.A., 1992, Groundwater- quality assessment of the Central Oklahoma aquifer, Oklahoma: Hydrologic, water-quality, and quality-assurance data 1987-90

Parkhurst, D.L., Christenson, Scott, and Breit, G.N., 1993, Ground-water-quality assessment of the Central Oklahoma aquifer, Oklahoma: Geochemical and geohydrologic investigations 16

\section{Professional Papers}

U.S. Geological Survey, 1954, Water-loss investigations, Lake Hefner studies, technical report 5 Ward, P.E., and Leonard, A.R., 1961, Hypothetical circulation of ground water around salt springs in western Oklahoma, Texas, and Kansas, in Geological Survey Research 1961 Leonard, A.R., and Ward, P.E., 1962, Use of $\mathrm{Na} / \mathrm{Cl}$ ratios to distinguish oil field from salt springs brines in western Oklahoma, in Geological Survey Research 1962 .... 5 Clark, W.E., 1963, Evapotranspiration and relation of ground water to surface water in the Pond Creek basin, Oklahoma, in Geological Survey Research 1962 5 Ward, P.E., 1962, Shallow halite deposits in the Flowerpot Shale in southwestern Oklahoma

Bergman, D.L., and Sullivan, C.W., 1963, Channel changes on Sandstone Creek near Cheyenne, Oklahoma, in Geological Survey Research 1963 .......................... 5 Bedinger, M.S., and Sneigocki, R.T., 1976, Summary appraisals of the Nation's ground-water resources-Arkansas-White-Red Region

\section{Water-Data Reports}

U.S. Geological Survey, 1976, Water resources data for Oklahoma, water year 1975

U.S. Geological Survey, 1977a, Water resources data for Oklahoma, water year 1976, Volume 1, Arkansas River basin 24 
WDR OK-76-2

WDR OK-77-1

WDR OK-77-2

WDR OK-78-1

WDR OK-78-2

WDR OK-79-1

WDR OK-79-2

WDR OK-80-1

WDR OK-81-1

WDR OK-82-1

WDR OK-83-1

WDR OK-84-1

WDR OK-85-1

WDR OK-86-1

WDR OK-87-1

WDR OK-88-1

WDR OK-89-1

WDR OK-90-1

WDR OK-91-1

WDR OK-92-1

WDR OK-92-2

WRI 2-76
U.S. Geological Survey, 1977b, Water resources data for Oklahoma, water year 1976, Volume 2, Red River basin 24 U.S. Geological Survey, 1978a, Water resources data for Oklahoma, water year 1977, Volume 1, Arkansas River basin 24 U.S. Geological Survey, 1978b, Water resources data for Oklahoma, water year 1977, Volume 2, Red River basin 24 U.S. Geological Survey, 1979a, Water resources data for Oklahoma, water year 1978, Volume 1, Arkansas River basin 24 U.S. Geological Survey, 1979b, Water resources data for Oklahoma, water year 1978, Volume 2, Red River basin 24 U.S. Geological Survey, 1981a, Water resources data for Oklahoma, water year 1979, Volume 1, Arkansas River basin 24 U.S. Geological Survey, 1981b, Water resources data for Oklahoma, water year 1979, Volume 2, Red River basin 24 U.S. Geological Survey, 1982, Water resources data for Oklahoma, water year 1980 , Volume 1 24 U.S. Geological Survey, 1983, Water resources data-Oklahoma, water year 1981 24 Hauth, L.D., Kurklin, J.K., Walters, D.M., and Ferree, D.M., 1984, Water resources data, Oklahoma, water year 1982 23 Hauth, L.D., Kurklin, J.K., and Walters, D.M., 1985, Water resources data for Oklahoma, water year 1983 23 Hauth, L.D., Kurklin, J.K., and Walters, D.M., 1986, Water resources data, Oklahoma, water year 1984 23 Hauth, L.D., Kurklin, J.K., Walters, D.M., and Coffey, T.E., 1987, Water resources data, Oklahoma, water year 1985

Hauth, L.D., Kurklin, J.K., and Walters, D.M., 1988, Water resources data, Oklahoma, water year 1986 23 Hauth, L.D., Walters, D.M., Coffey, T.E., and White, D.K., 1989, Water resources data, Oklahoma, water year 1987 23 Hauth, L.D., Walters, D.M., Coffey, T.E., and White, D.K., 1990, Water resources data, Oklahoma, water year 1988 23 Blazs, R.L., Boyle, D.L., Coffey, T.E., Walters, D.M., and White, D.K., 1990, Water resources data for Oklahoma, water year 1989 23 Blazs, R.L., Walters, D.M., Coffey, T.E., White, D.K., and Boyle, D.L., 1991, Water resources data for Oklahoma, water year 1990 ........................................... 23 Blazs, R.L., Walters, D.M., Coffey, T.E., White, D.K., Boyle, D.L., and Kerestes, J.F., 1992, Water resources data for Oklahoma, water year 1991 23 Blazs, R.L., Walters, D.M., Coffey, T.E., White, D.K., Boyle, D.L., and Kerestes, J.F., 1993, Water resources data for Oklahoma, water year 1992, Volume 1, Arkansas River basin 23 Blazs, R.L., Walters, D.M., Coffey, T.E., White, D.K., Boyle, D.L., and Kerestes, J.F., 1993, Water resources data for Oklahoma, water year 1992, Volume 2, Red River basin 23

\section{Water-Resources Investigations}

Thomas, W.O., Jr., 1976, Techniques for estimating flood depths for Oklahoma streams 
WRI 5-73

WRI 23-74

WRI 25-75

WRI 27-74

WRI 52-73

WRI 77-54

WRI 78-70

WRI 81-65

WRIOFR 81-100

WRIOFR 81-1187

WRIOFR 81-275

WRIOFR $81-760$

WRIOFR 81-1117

WRIOFR 83-266

WRIOFR 84-129

WRIR 80-120

WRIR 81-0033

WRIR 81-0039

WRIR 81-0080
Thomas, W.O., Jr., and Corley, R.K., 1973, 1971-72 Floods of Glover Creek and Little River in southeastern Oklahoma

Sauer, V.B., 1974b, An approach to estimating flood frequency for urban areas in

Oklahoma 20

Hart, D.L., Jr., Hoffman, G.L., and Goemaat, R.L., 1976, Geohydrology of the Oklahoma Panhandle, Beaver, Cimarron, and Texas Counties

Bingham, R.H., Bergman, D.L., and Thomas, W.O., Jr., 1974, Flood of October 1973

in Enid and vicinity, north-central Oklahoma .......................................... 18

Sauer, V.B., 1974a, Flood characteristics of Oklahoma streams ..................... 20

Thomas, W.O., Jr., and Corley, R.K., 1977, Techniques for estimating flood discharges for Oklahoma streams

Weeks, J.B., 1978, Plan of study for the High Plains regional aquifer systems analysis in parts of Colorado, Kansas, New Mexico, Oklahoma, South Dakota, Texas, and Wyoming

Feder, G.L., and Krothe, N.C., 1981, Results of a reconnaissance water-quality sampling program of the Ogallala aquifer in Colorado, Kansas, Nebraska, Oklahoma, South Dakota, and Texas

\section{Water-Resources Investigations Open-File Reports}

Havens, J.S., 1982a, Altitude and configuration of the 1980 water table in the High Plains regional aquifer, northwestern Oklahoma

Marcher, M.V., Bergman, D.L., Stoner, J.D., and Blumer, S.P., 1981, Preliminary appraisal of the hydrology of the Blocker area, Pittsburg County, Oklahoma ..... 19 Havens, J.S., 1982b, Altitude and configuration of the predevelopment water table in the High Plains regional aquifer, northwestern Oklahoma

Havens, J.S., 1982c, Saturated thickness of the High Plains regional aquifer in 1980, northwestern Oklahoma

Havens, J.S., 1982d, Generalized altitude and configuration of the base of the High Plains regional aquifer, northwestern Oklahoma

Marcher, M.V., Kenny, J.F., and others, 1984, Hydrology of Area 40, Western

Region, Interior Coal Province, Kansas, Oklahoma, and Missouri 20

Marcher, M.V., Bergman, D.L., Slack, L.J., and Blumer, S.P., 1984, Hydrology of Area 41, Western Region, Interior Coal Province, Oklahoma and Arkansas

\section{Water-Resources Investigations Reports}

Reed, J.E., 1982, Preliminary projections of the effects of chloride-control structures on the Quaternary aquifer at Great Salt Plains, Oklahoma 20 Stoner, J.D., 1981a, Water type and suitability of Oklahoma surface waters for public supply and irrigation, Part 1-Arkansas River mainstem and Verdigris, Neosho, and Illinois River basins through 1978 20 Stoner, J.D., 1981b, Water type and suitability of Oklahoma surface waters for public supply and irrigation, Part 2-Salt Fork Arkansas and Cimarron River basins through 1978 21

Stoner, J.D., 1981c, Water type and suitability of Oklahoma surface waters for public supply and irrigation, Part 3-Canadian, North Canadian, and Deep Fork River basins through 1979 21 
WRIR 82-0009

WRIR 82-0012

WRIR 82-0029

WRIR 82-0040

WRIR $82-4099$

WRIR 83-4013

WRIR 83-4073

WRIR 83-4076

WRIR $83-4166$

WRIR 83-4202

WRIR 83-4223

WRIR 83-4269

WRIR 84-4358

WRIR 85-4039

WRIR 85-4084

WRIR 86-4169

WRIR 86-4355

WRIR 87-4205

WRIR 88-4208

WRIR 88-4234

Stoner, J.D., 1982a, Water type and suitability of Oklahoma surface waters for public supply and irrigation, Part 4 Red River mainstem and North Fork Red River through 1979

Krothe, N.C., and Oliver, J.W., 1982, Sulfur isotopic composition and water chemistry in water from the High Plains aquifer, Oklahoma Panhandle and southwestern

Kansas 19

Stoner, J.D., 1982b, Water type and suitability of Oklahoma surface waters for public supply and irrigation, Part 5-Washita River basin through 1979 21 Heimes, F.J., and Luckey, R.R., 1982, Method for estimating historical irrigation requirements from ground water in the High Plains in parts of Colorado, Kansas, Nebraska, New Mexico, Oklahoma, South Dakota, Texas, and Wyoming ........ 19 Marcher, M.V., Huntzinger, T.L., Stoner, J.D., and Blumer, S.P., 1983, Preliminary appraisal of the hydrology of the Stigler area, Haskell County, Oklahoma ........ 20 Marcher, M.V., Bergman, D.L., Stoner, J.D., and Blumer, S.P., 1983a, Preliminary appraisal of the hydrology of the Rock Island area, Le Flore County, Oklahoma 20 Havens, J.S., 1983, Water-level changes in the High Plains regional aquifer, northwestern Oklahoma, predevelopment to 1980 19 Christenson, S.C., 1983, Numerical simulation of the alluvium and terrace aquifer along the North Canadian River from Canton Lake to Lake Overholser, central Oklahoma 18 Marcher, M.V., Bergman, D.L., Stoner, J.D., and Blumer, S.P., 1983b, Preliminary appraisal of the hydrology of the Red Oak area, Latimer County, Oklahoma ..... 20 Slack, L.J., 1983, Hydrology of an abandoned coal-mining area near McCurtain, Haskell County, Oklahoma 20 Stoner, J.D., 1984, Estimate of self-supplied domestic water use in Oklahoma during 1980 21

Havens, J.S., and Christenson, S.C., 1983, Numerical simulation of the High Plains regional aquifer, northwestern Oklahoma 19 Tortorelli, R.L., and Bergman, D.L., 1984, Techniques for estimating flood peak discharges for unregulated streams and streams regulated by small floodwater retarding structures in Oklahoma 21 Kurklin, J.K., 1985, Water quality in the Blue Creek arm of Lake Eufaula and Blue Creek, Oklahoma, March-October 1978

Stoner, J.D., 1985, Reported withdrawals and estimated use of water in Oklahoma during 1982 21 Kurklin, J.K., 1990, Water quality in Gaines Creek and Gaines Creek arm of Eufaula Lake, Oklahoma 19 Parkhurst, R.S., and Christenson, S.C., 1987, Selected chemical analyses of water from formations of Mesozoic and Paleozoic age in parts of Oklahoma, northem Texas, and Union County, New Mexico 20 Heimann, D.C., and Tortorelli, R.L., 1988, Statistical summaries of streamflow records in Oklahoma in parts of Arkansas, Kansas, Missouri, and Texas through 1984

Morton, R.B., 1992, Simulation of ground-water flow in the Antlers aquifer in southeastem Oklahoma and northeastem Texas 20 Havens, J.S., 1989, Geohydrology of the alluvial and terrace deposits of the North Canadian River from Oklahoma City to Eufaula Lake, central Oklahoma 19 
WRIR 89-4159 Scott, J.C., 1990a, A statistical processor for analyzing simulations made using the modular finite-difference ground-water flow model .................................. 20

WRIR 89-4172 Scott, J.C., 1989, A computerized data-base system for land-use and land-cover data collected at ground-water sampling sites in the pilot National Water-Quality Assessment program

WRIR 90-4101

WRIR 90-4200

Scott, J.C., 1990b, Computerized stratified random site-selection approaches for

design of a ground-water-quality sampling network

Scott, J.C., 1991, Computer software for converting ground-water and water-quality data from the National Water Information System for use in a geographic information system 20

\section{Water-Supply Papers}

WSP 0148

WSP 0345-B

WSP 0345-D

WSP 0500-B

WSP 0520-B

WSP 1227-B

WSP 1669-K

WSP 1800

WSP 1809-T

WSP 1839-C

WSP 1890

WSP 1971

WSP 1999-A

WSP 2250

WSP 2275

WSP 2275

WSP 2300

WSP 2325

Gould, C.N., 1905, Geology and water resources of Oklahoma

Schwenneson, A.T., 1915a, Ground water for irrigation in the vicinity of Enid, Oklahoma

Schwenneson, A.T., 1915b, Ground water for irrigation in the valley of North Fork of Canadian River near Oklahoma City, Oklahoma

Thompson, D.C., 1922, Ground water for irrigation near Gage, Ellis County, Oklahoma

Renick, B.C., 1925, Additional water supplies for the city of Enid, Oklahoma .... 6 U.S. Geological Survey, 1954, Floods of May 1951 in western Oklahoma and northwestern Texas 7 Marine, I.W., 1963, Correlation of water-level fluctuations with climatic cycles in the Oklahoma Panhandle 6 Leonard, A.R., 1963, Oklahoma, in The role of ground water in the Nation's water situation

Tanaka, H.H., Hollowell, J.R., and Murphy, J.J., 1966, Hydrology of the alluvium of the Arkansas River, Muskogee, Oklahoma, to Fort Smith, Arkansas, with a section on Chemical quality of the water, by J.J. Murphy

Kennon, F.W., 1966, Hydrologic effects of small reservoirs in Sandstone Creek watershed, Beckham and Roger Mills Counties, western Oklahoma ................. 6 Dover, T.B., Leonard, A.R., and Laine, L.L., 1968, Water for Oklahoma ............ 6 Bedinger, M.S., Reed, J.E., Wells, C.V., and Swafford, B.F., 1970, Methods and applications of electrical simulation in ground-water studies in the lower Arkansas and Verdigris River valleys, Arkansas and Oklahoma 5 Tanaka, H.H., 1972, Geohydrology of the lower Verdigris River valley between Muskogee, and Catoosa, Oklahoma ............................................................. 6 U.S. Geological Survey, 1984, Oklahoma water issues, in U.S. Geological Survey, 1984, National Water Summary 1983-Hydrologic events and issues 7 Havens, J.S., Marcher, M.V., and Schuelein, J.W., 1985, Oklahoma-Ground-water resources, in U.S. Geological Survey, 1985, National Water Summary 1984 ....... 6 Stoner, J.D., 1985, Dissolved solids in the Arkansas River Basin, in U.S. Geological

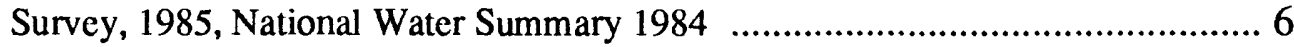
Blumer, S.P., 1986, Oklahoma, Surface-water resources, in U.S. Geological Survey, 1986, National Water Summary, 1985 5 Horak, W.F., and Stoner, J.D., 1988, Oklahoma-Ground-water quality, in U.S. Geological Survey, 1988, National Water Summary 1986 6 

homa-Water supply and use, in U.S. Geological Survey, 1990, National Water Summary 1987 6

WSP 2375 Hanson, R.L., 1991, Evapotranspiration and droughts, in U.S. Geological Survey, 1991, National Water Summary 1988-89

WSP 2375 Tortorelli, R.L., Cooter, E.J., and Schuelein, J.W., 1991, Oklahoma-Floods and droughts, in U.S. Geological Survey, 1991, National Water Summary 1988-89 .. 6 